NUREG/CR-2340 RAE 18-1

PNL-4084

\title{
A Handbook for the Determination of Radon Attenuation Through Cover Materials
}

Prepared by V. C. Rogers, K. K. Nielson

Rogers and Associates Engineering Corporation

Pacific Northwest Laboratory

Operated by

Battelle Memorial Institute

Prepared for

U.S. Nuclear Regulatory

Commission 


\section{NOTICE}

This report was prepared as an account of work sponsored by an agency of the United States Government. Neither the United States Government nor any agency thereof, or any of their employees, makes any warranty, expressed or implied, or assumes any legal liability or responsibility for any third party's use, or the results of such use, of any information, apparatus product or process disclosed in this report, or represents that its use by such third party would not infringe privately owned rights.

\section{Available from}

GPO Sales Program

Division of Technical Information and Document Control

U. S. Nuclear Regulatory Commission Washington, D. C. 20555

Printed copy price: $\$ 4.75$

and 


\section{A Handbook for the Determination of Radon Attenuation Through Cover Materials}

Manuscript Completed: November 1981

Date Published: December 1981

Prepared by

V. C. Rogers, K. K. Nielson

Rogers and Associates Engineering Corporation

P.O. Box 330

Salt Lake City, UT 84110

Under Subcontract to

Pacific Northwest Laboratory

Richland, WA 99352

\section{Prepared for}

Division of Health, Siting and Waste Management

Office of Nuclear Regulatory Research

U.S. Nuclear Regulatory Commission

Washington, D.C. 20555

NRC FIN B2269 


\section{Availability of Reference Materials Cited in NRC Publications}

Most documents cited in NRC publications will be available from one of the following sources:

1. The NRC Public Document Room, 1717 H Street., N.W. Washington, DC 20555

2. The NRC/GPO Sales Program, U.S. Nuclear Regulatory Commission, Washington, DC 20555

3. The National Technical Information Service, Springfield, VA 22161

Although the listing that follows represents the majority of documents cited in NRC publications, it is not intended to be exhaustive

Referenced documents available for inspection and copying for a fee from the NRC Public Document Room include NAC correspondence and internal NAC memoranda; NRC Office of Inspection and Enforcement bulietins, circulars, information notices, inspection and investigation notices; Licensee Event Reports; vendor reports and correspondence; Commission papers; and applicant and licensee documents and correspondence.

The following documents in the NUREG series are available for purchase from the NRC/GPO Sales Program: formal NAC staff and contractor reports, NAC-sponsored conference proceedings, and NAC booklets and brochures. Also available are Regulatory Guides, NAC regulations in the Code of Federal Regulations, and Nuclear Regulatory Commission issuances.

Documents available from the National Technical Information Service include NUREG series reports and technical reports prepared by other federal agencies and reports prepared by the Atomic Energy Commission, forerunner agency to the Nuclear Regulatory Commission.

Documents available from public and special technical libraries include all open literature items, such as books, journal and periodical articles, transactions, and codes and standards. Federal Register notices. federai and state legislation, and congressional reports can usually be obtained from these libraries.

Documents such as theses, dissertations, foreign reports and translations, and non-NRC conference proceedings are available for purchase from the organization sponsoring the publication cited.

Single copies of NAC draft reports are available free upon written request to the Division of Technical Information and Document Control, U.S. Nuclear Regulatory Commission, Washington, DC 20555. 
ABSTRACT

Radon emissions from bare and covered uranium mill tailings can be estimated by diffusion theory if appropriate diffusion coefficients are known.

The mathematical bases for the diffusion theory expressions are herein presented, as is a general survey of previous and present research, as well as technological developments associated with radon transport through tailings cover systems.

Research is presently being conducted to define more clearly the influences of moisture, porosity, pore size distribution and other factors, on the attenualive properties of cover materials. The results of these present investigations will be incorporated in a subsequent addendum to this handbook.

The radon fluxes or cover thicknesses can be calculated by hand or by available computer programs. The equations and procedure for the hand calculations is in direct support of the methodology contained in Appendix $P$ of the Generic Environmental Impact Statement on Uranium Milling. Several examples are given to demonstrate the methodology.

For most practical cases, the effect of the radon in the cover material can be neglected, if the radium concentration in the cover is at background levels. 

1. INTRODUCTION . . . . . . . . . . . . . . . . . . . . . 1

1.1 Organization of Handbook . . . . . . . . . . . . . . 1

1.2 Background and Previous Work ............. 2

2. MATHEMATICAL BASIS OF RADON DIFFUSION THROUGH COVERS ....... 7

2.1 Diffusion Through One and Two Regions . . . . . . . . 8

2.2 General Solution and Boundary Conditions . . . . . . . . 10

2.3 Solution For Radon Flux Across the Surface of Bare Tailings . . II

2.4 Solution for Covered Tailings . . . . . . . . . . . . . 13

2.5 Multiregion Solution ................ 15

2.5.1 General Multilayer Expression .......... 15

2.5.2 Numerical Solution for Multilayer Systems . . . . . . 24

2.6 Approximate Expressions . . . . . . . . . . . . . . 26

3. APPLICATION OF CALCULATION METHODS .............. 33

3.1 Source Term Definition . . . . . . . . . . . 33

3.2 Diffusion Coefficients . . . . . . . . . . . . 34

3.3 Surface Flux and Cover Thickness Determination . . . . . . 40

3.4 Examples ..................... . . . 42

3.5 Example Calculations with RAECO ............. 47

3.6 Cover Source Considerations . . . . . . . . . . . . . 47

4. SUMMARY AND CONCLUSIONS ................. 53

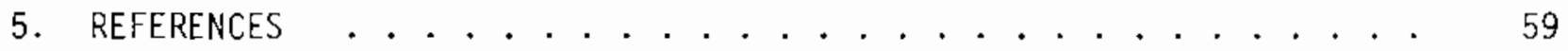

APPENDIX A - INPUT DATA FORMAT FOR RAECO PROGRAM AND RAECO PROGRAM LISTINGS . . . . . . . . . . . . . . A A-1

APPENDIX B - TABLES OF REQUIRED DEPTHS FOR RADON ATTENUATION . . . . B B-1 



\section{LIST OF FIGURES}

Figure $1.1{ }^{238_{U}}$ Decay Scheme .................... 3

Figure 2.1 Boundary and Interface Conditions for Solving the Diffusion Equations .................... . . 12

Figure 2.2 Cover Surface Radon Flux for Various Thicknesses and Parameters . . . . . . . . . . . . . 16

Figure 2.3 Multilayered Taitings Cover System . . . . . . . . . . . 18

Figure 2.4 Matrix Representation of Equations for Determining the

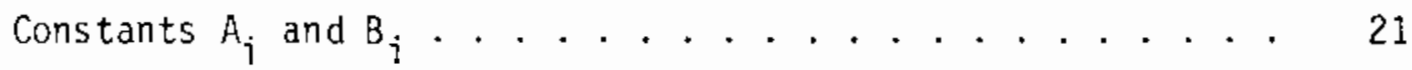

Figure 2.5 Modified Matrix . . . . . . . . . . . . . . . 23

Figure 2.6 Major Components of RAECO Mode1 . . . . . . . . . . . . 25

Figure 3.1 Moisture Dependence of the Diffusion Coefficient . . . . . 37

Figure 3.2 Diffusion Coefficient as a Function of Air Fizled Porosity. . 38

Figure 3.3 Effect of SoiT Thickness on Radon Exhalation Rate . . . . . 41

Figure 3.4 Taitings Cover Thickness Variation with Porosity Ratio, Tailings Moisture and Ore Grade............ 


\section{LIST OF TABLES}

Table 3.1 Bulk Diffusion Coefficients for Radon in Various Media . . . 35

Table 3.2 Input Data Set for RAECO Calculations of Example Problems. . 48

Table 3.3 RAECO Calculation of Example 1 . . . . . . . . . . . . . 49

Table 3.4 RAECO Calculation of Example 2 . . . . . . . . . . . . 50

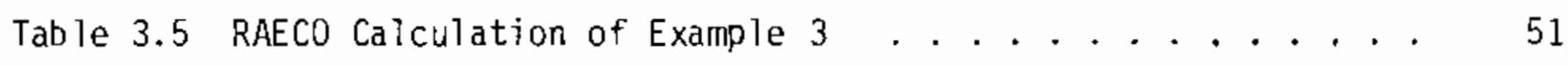

Table 4.1 Procedural Checklist for Calculating Adequate Cover

Thickness ................... . . . 54 


\section{INTRODUCTION}

Radon emissions from uranium mill tailings have long been recognized as a major potential health hazard. During the milling of uranium ore, the ore is crushed to facilitate processing and a negligible fraction of radium, the parent of radon, is removed. Consequently, the accessibility of radon to the environment is generally increased.

An important feature of any uranium mill tailings management program is the proper long-term stabilization of the tailings to adequately reduce radon emissions. The generally accepted means of achieving stabilization is to cover the tailings with earthen materials, sumetimes supplemented by layers of mannade materials. It is therefore important to accurately determine the radon attenuating properties of cover materials and cover systems. This handbook provides the basis, the methodology, and the standardized procedures for calculating the radon attenuation provided by cover systems placed over uranium mill tailings impoundments, based on currently available data. Research is presently being conducted to define more clearly the influences of moisture, porosity, pore size distribution and other factors on the attenuative properties of cover materials. The results of these investigations will be incorporated in a subsequent addendum to this handbook.

\subsection{ORGANIZATION OF HANDBOOK}

This handbook addresses the following four main topics important in radon attenuation cover design effectiveness evaluations:

1. An identification of current research and development activities relating to radon transport through materials. 
2. A complete foundation for the calculation of radon transport and attenuation through cover materials.

3. Documentation of the relevant expressions contained in Appendix $P$ of the Final Generic Environmental Impact Statement on Uranium Milling.

4. A concise set of procedures for calculating cover thicknesses required to satisfy the design criterion using both exact and approximate expressions.

The identification of research and development activities is presented in the following section of this chapter. Chapter 2 contains the mathematical basis for calculating radon attenuation through cover materials, including the documentation of relevant expressions in Appendix $P$ of Reference 1 . The procedures for calculating the required cover thickness are given in Chapter 3 , along with several examples, and Chapter 4 contains the conclusions, summary and a procedural check list for calculating adequate cover thicknesses.

\subsection{BACXGROUND AND PREVIOUS WORK}

Radon does not combine readily with other elements because it is a chemically inert gas. The principal isotope of radon, ${ }^{222} \mathrm{Rn}$, is generated from the radioactive decay of ${ }^{226} \mathrm{Ra}$ and is a decay daughter in the ${ }^{238} \mathrm{U}$ decay series as shown in Figure 1.1. The half-life of radon, $T_{\frac{1}{2}}$, is 3.8 days which allows the radon to migrate considerable distances before decaying. Furthermore, the generation of ${ }^{222} \mathrm{Rn}$ continues at its current rate for many thousands of years due to the relatively long half-lives of ${ }^{226} \mathrm{Ra}$, and its parent, ${ }^{230} \mathrm{Th}$, which are both present in the tailings. 


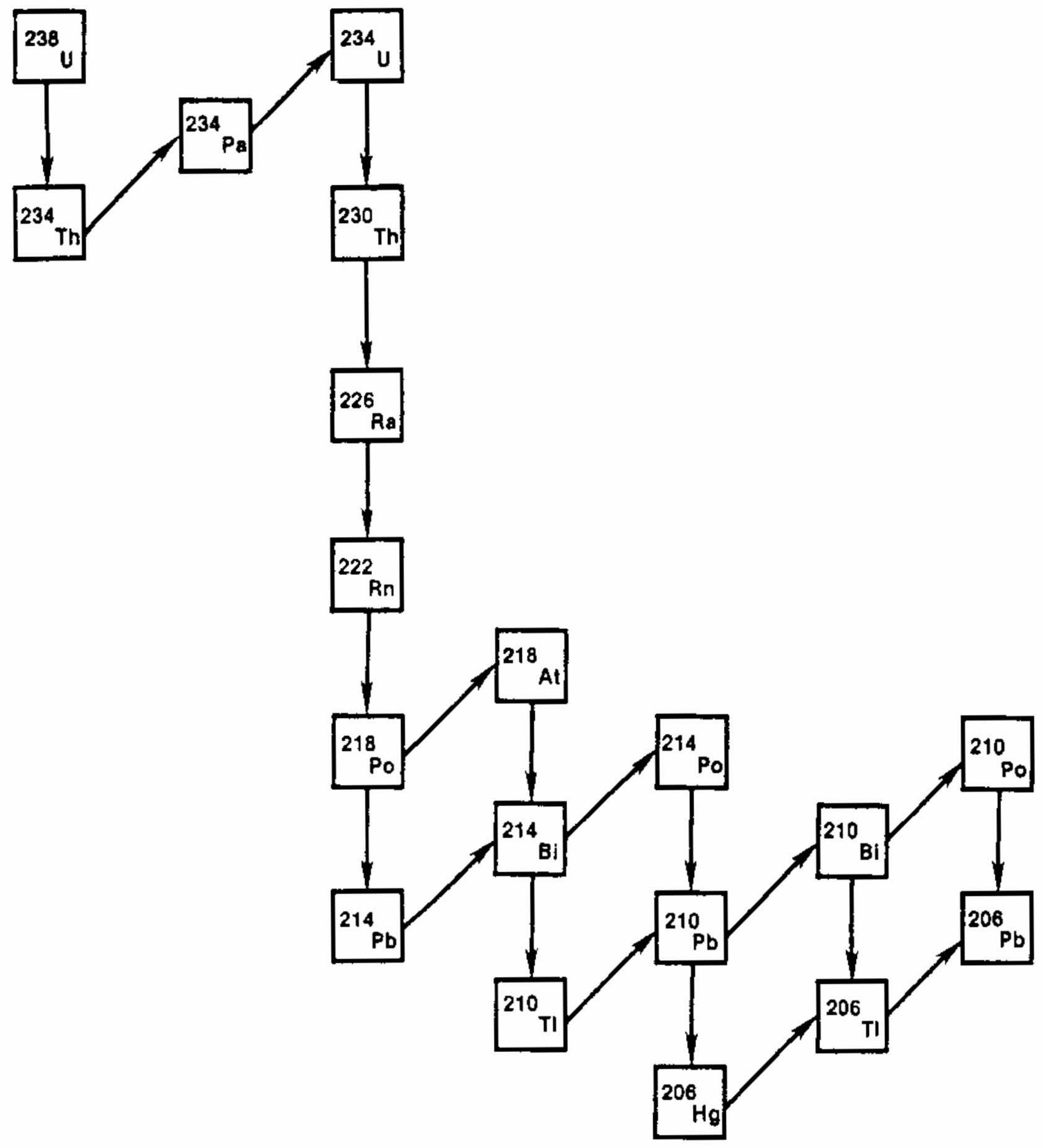

FIGURE $1.1 \quad 238_{\text {U DECAY SCHEME }}$

3 
The calculation of the thicknesses of cover materials required to attenuate radon flux to near-background levels is generally based upon diffusion theory. The effectiveness of a particuiar cover material in attenuating radon release depends upon that material's ability to restrict the diffusion long enough so that, before the radon can completely penetrate the material, it will decay to a solid daughter product and will consequently remain trapped in the material. The parameter that characterizes this material property is called the diffusion coefficient.

Researchers have long been interested in the diffusion and transport of radon through porous materials. Early studies of radon in the natural environment ${ }^{(2-11)}$ have been supplemented by research dealing specifically with the diffusion and transport of radon produced in uranium mill tailings $(9,12-14)$ and ore minerals. $(15,16)$ In particular, References 8 and 17 contain excellent reviews of the general topic, and Reference 18 contains a comprehensive bibliography on the effects of radon moisture on emanation and diffusion.

Among the first major studies concerned with the diffusion of radon from uranium milt tailings are those reported in References 12-14. These studies were based on experiments with the diffusion of radon through tailings, soi] and concrete. Measurements made during these experiments were compared with diffusion theory modeling and from the comparison, diffusion coefficients were deduced. In other laboratory experiments, $(19,20)$ the diffusion of radon through various tailings and cover materials was measured. Diffusion coefficients were deduced from both radon fluxes and from radon gas concentration profiles. Two recent field tests $(21,22)$ using uranium tailings materials also have yieided information associated with the diffusion coefficient. In one test (21) surface radon fluxes were measured for various thicknesses of a cover material placed over a small plot of tailings. The diffusion coefficient obtained from 
a least-squares fit of the flux data was consistent with the laboratory measurement of similar material. (21) In the other fjeld measurement ${ }^{(22)}$ the diffusion coefficient was deduced from in-site borehole logging of the ${ }^{226} \mathrm{Ra}$ and ${ }^{222} \mathrm{Rn}$ concentrations in acidic and alkaline tailings.

In Reference 20 , it was found that the diffusion coefficients for a wide variety of materials could be approximated by the following simple correlation involving moisture and the diffusion coefficient of radon in air:

$$
D_{e}=D_{a i r}^{0} P \exp (-0.261 M),
$$

where

$$
\begin{aligned}
D_{e}= & \text { effective bulk diffusion coefficient }\left(\mathrm{cm}^{2} / \mathrm{s}\right) \\
D_{\text {air }=}^{0} & \text { diffusion coefficient of radon in air }\left(0.106 \mathrm{~cm}^{2} / \mathrm{sec}\right) \\
p= & \text { total porosity of material } \\
M= & \text { weight-percent of moisture in the porous material, } \\
& \text { (i.e., grams water per gram wet sample) }
\end{aligned}
$$

The same data were used in Reference 23 to obtain a correlation similar in form to other correlations of gaseous diffusion through porous materials. (24)

The correlation based upon the air-filled porosity, $p_{a}$, is:

$$
D_{e}=0.74 D_{a i r}^{0} p_{a}^{2.16}+D_{w} \theta
$$

where

$$
\begin{aligned}
\theta= & \text { volume fraction of moisture } \\
P_{a}= & \text { air filled porosity }=p-0 \\
D_{w}= & \text { diffusion coefficient in water-filled } \\
& \text { pores (assumed to be } 6.6 \times 10^{-6} \mathrm{~cm}^{2} / \mathrm{sec} \text { ) }
\end{aligned}
$$


The radon transport through synthetic materials can also be described with diffusion theory with a material diffusion coefficient characterizing the diffusion. For these materials the porosity is unity. Diffusion coefficients for several synthetic materials are presented in Reference 25 .

The same authors also reported preliminary results $(19)$ with a clay-gravel aggregate that has a low air-filled porosity. Initial results with the aggregate suggested further development $(19,25)$ and work is continuing in this area.

Other recent laboratory efforts have been focusing on diffusion coefficient measurements using small samples. $(25-30)^{\star}$ In some of the methods, the effects the diffusion coefficient have upon a transient release of radon are measured. In others, $(29,30)^{\star}$ two steady-state measurements are used to obtain a value for the diffusion coefficient. These methods generally yield diffusion coefficients that are smaller for the same conditions than those obtained from flux measurements on a large sample.

The radon flux reduction capability of synthetic materials has also been studied by several researchers. The primary concern with synthetic materiais is their ability to maintain their integrity for the lengthy period of time that is required. Asphalt emulsions have been developed as radon sealants and initial results from the most recent field test are promising. $(31,32)$ The Bureau of Mines has been studyina foams, enoxy sealants and other materials as radon barriers for worked-out mine stopes. (33) Additionaliy, several materials have been identified as effective for the short-term reduction of radon in active mines.

The radon-attenuating properties of additional synthetic-materials are reported in References $19,25,26$ and 34 . Materials such as aspha1t, EPDM rubber, Polyethylene sheets, Polycarbonate sheets, and Mylar are characterized by diffusion coefficients of less than $10^{-6} \mathrm{~cm}^{2} / \mathrm{sec}$. (25)

$\overline{\star(R e f .30)}$ Private communication between $W$. Silker (PNL) and V.C. Rogers (RAE), 1981. 


\section{MATHEMATICAL BASIS OF RADON DIFFUSION THROUGH COVERS}

The physical processes by which radon can be transported from one point to another are both numerous and complex. In general these processes may be categorized into the two general groupings, of microscopic transport processes and macroscopic transport processes.

Macroscopic transport accounts for those transport processes in which radon atoms become intimately associated with their surrounding medium which itself is undergoing transport. For example the absorption of radon in ground water and subsequent flow of that water is a macroscopic radon transport process. In the overalt movement of radon in containment systems, macroscopic processes can be important, but they are usually identified and evaluated separately. A recent

evaluation (35) has shown that the macroscopic transport from diurnal atmospheric pressure variations is negligible when averaged over long periods.

In this handbook only microscopic transport of radon will be considered. Microscopic transport of radon is the set of processes by which individual free atoms of radon move as a consequence of momentum, themal or mass gradients imposed upon the spatial radon distribution. Molecular diffusion of radon is one type of microscopic transport process.

If the spatial distribution of radon atoms existing within a containment volume exhibits a variation in concentration, a net flow of individual radon atoms will arise to reduce the concentration gradient. This particular microscopic transport process is generally referred to as simple molecular diffusion and is described mathematically by Fick's law of diffusion.

If a temperature or momentum gradient exists with in a containment volume which includes radon, then a microscopic transport flow of radon will arise to minimize these gradients aiso. However, microscopic transport of radon arising 
from thermal or momentum gradients is generally negligible for long times in uraniurn taitings cover systems, and may therefore be ignored.

Only the microscopic transport of radon through a multiregion porous media system such as a covered tailings pile, as described mathematically by Fick's law of diffusion, will be considered in this handbook. Other transport mechamisms, such as advection, can often be accomodated by a suitable selection of the numerical value of the diffusion coefficient and thereby use the same mathematical formal ism.

\subsection{DIFFUSION THROUGH ONE AND TWO REGIONS}

The general diffusion equation for the long-term steady state condition is derived from the steady state equation of continuity where, for a particular infinitesimal volume in the tailings or cover material, the radon generation rate equals the loss rate from leakage and decay:

$$
\nabla \cdot \bar{J}+p \lambda C=Q
$$

where

$$
\begin{aligned}
\bar{J} & =\text { radon flux from the porous material }\left(\mathrm{pCi} / \mathrm{m}^{2} \mathrm{~s}\right) \\
\nabla \cdot \bar{J} & =\text { radon leakage from the infinitesimal volume }\left(\mathrm{pCi} / \mathrm{m}^{3} \mathrm{~s}\right) \\
\mathrm{p} & =\text { total porosity of the material } \\
\lambda & =\text { decay constant of radon }\left(2.1 \times 10^{-6} \mathrm{sec}^{-1}\right) \\
\mathrm{C} & =\text { radon concentration in the total pore space }\left(\mathrm{pCi} / \mathrm{m}^{3}\right) \\
Q & =\text { radon source term }\left(\mathrm{pCi} / \mathrm{m}^{3} \mathrm{~s}\right)
\end{aligned}
$$

The first term in the left-hand side of Eq 2-1 represents the 1os sy 
leakage from the infinitesimal volume and the second term is the loss by radioactive decay in the volume. The source term in the volume is generally calculated from the following expression:

$$
Q=R_{b} E \lambda
$$

where

$$
\begin{aligned}
R= & { }^{226} \mathrm{Ra} \text { content of the dry material } \\
& (\mathrm{pCi} / \mathrm{g}) \\
P_{D}= & \text { dry bulk density of the material }\left(\mathrm{g} / \mathrm{m}^{3}\right) \\
E= & \text { emanating power }
\end{aligned}
$$

The emanating power is the fraction of radon that escapes the mineral grains and enters the pore space following its production.

In diffusion theory it is assumed that the flux is proportional to the concentration gradient, as given by Fick's law. For a one-dimensional system this is:

$$
J(x)=-D_{e} \frac{d C}{d x}
$$

Where $D_{e}$ is the effective bulk radon diffusion coefficient relating the gradient of the radon concentration in the pore space to the total radon flux $J$ of the porous material. Because the ratio $D_{e} / p$ often appears in the diffusion expressions, it can be related to radon attenuation measurements. It is known as the diffusion coefficient of the porous medium, $D^{\star}$, but will not be used in the expressions involving the diffusion coefficient in this report. It is only used in the Table of diffusion coefficients, Table 3.1. From this point on, $D$ in the text is meant to represent the effective bulk diffusion coefficient even 
if the subscript e is omitted. The diffusion coefficient can be determined experimentally for particular materials by measuring the radon attenuation through the material and relating the resulting attenuation to the diffusion theory expression. Radon flux measurements $(12,19,20)$ have been used to deduce $\mathrm{D}_{\mathrm{e}}$, as have radon concentration measurements in the soil gas of the material $(7,20)$ and the time-dependent break-point of radon migrating through the material $(25,26,28)$ With Fick's Law, Eq 2-1 becomes, for a one-dimensional problem:

$$
D_{e} \frac{d^{2} C}{d x^{2}}-p \lambda C+R_{p b} E \lambda=0
$$

Radon diffusion has also been described ${ }^{(23)}$ by Eq $2-3$ using the air-filled porosity for $P$, and $E q$ 1-2 for $D_{e}$.

\subsection{GENERAL SOLUTION AND BOUNDARY CONDITIONS}

The general solution to Eq 2-3, assuming constant coefficients, is

$$
c(x)=A \exp (b x)+B \exp (-b x)+S,
$$

where

$$
\begin{aligned}
\mathrm{b} & =\left(\lambda \mathrm{p} / D_{\mathrm{e}}\right)^{\frac{1}{2}} \\
\mathrm{~S} & =\mathrm{R}_{\mathrm{b}} \mathrm{E} / \mathrm{p} \\
\mathrm{A}, \mathrm{B} & =\text { integration constants }
\end{aligned}
$$

The associated radon flux, obtained from Eqs 2-2 and 2-4 is

$$
J=-D_{e} b[A \exp (b x)-B \exp (-b x)]
$$


The integration constants $A$ and $B$ are determined from the boundary conditions of the problem.

The boundary conditions used to evaluate the constants, as shown in Figure 2. 1, are:

1. $\mathrm{J}(0)=0$

2. $c_{i}\left(x_{j}\right)=c_{j+1}\left(x_{j}\right)$

3. $J_{i}\left(x_{i}\right)=J_{i+1}\left(x_{i}\right)$

4. $C_{n}\left(x_{n}\right)=C_{a}$ the flux is zero at the origin

the concentration is continuous across a media interface at $x_{i}$ the radon flux is continuous across a media interface at $x_{i}$

the concentration at the surface of the top layer (medium $n$ ) is equal to a specified value

\subsection{SOLUTION FOR RADON FLUX ACROSS THE SURFACE OF BARE TAILINGS}

Application of boundary condition 1 to Eq 2-6 yields $A=B$, so that $E q$ 2-4 becomes

$$
C(x)=A\left[\exp \left(b_{0} x\right)+\exp \left(-b_{0} x\right)\right]+R p_{b} E / p_{0}
$$

where the zero subscript indicates that the parameter is that value for tailings. Application of boundary condition 4 for $c_{a}=0$ at the top surface of the tailings, $x=x_{0}$, yields

$$
A=\frac{-R_{p} E}{p_{0}\left[\exp \left(b_{0} x_{0}\right)^{-}+\exp \left(-b_{0} x_{0}\right)\right]}
$$




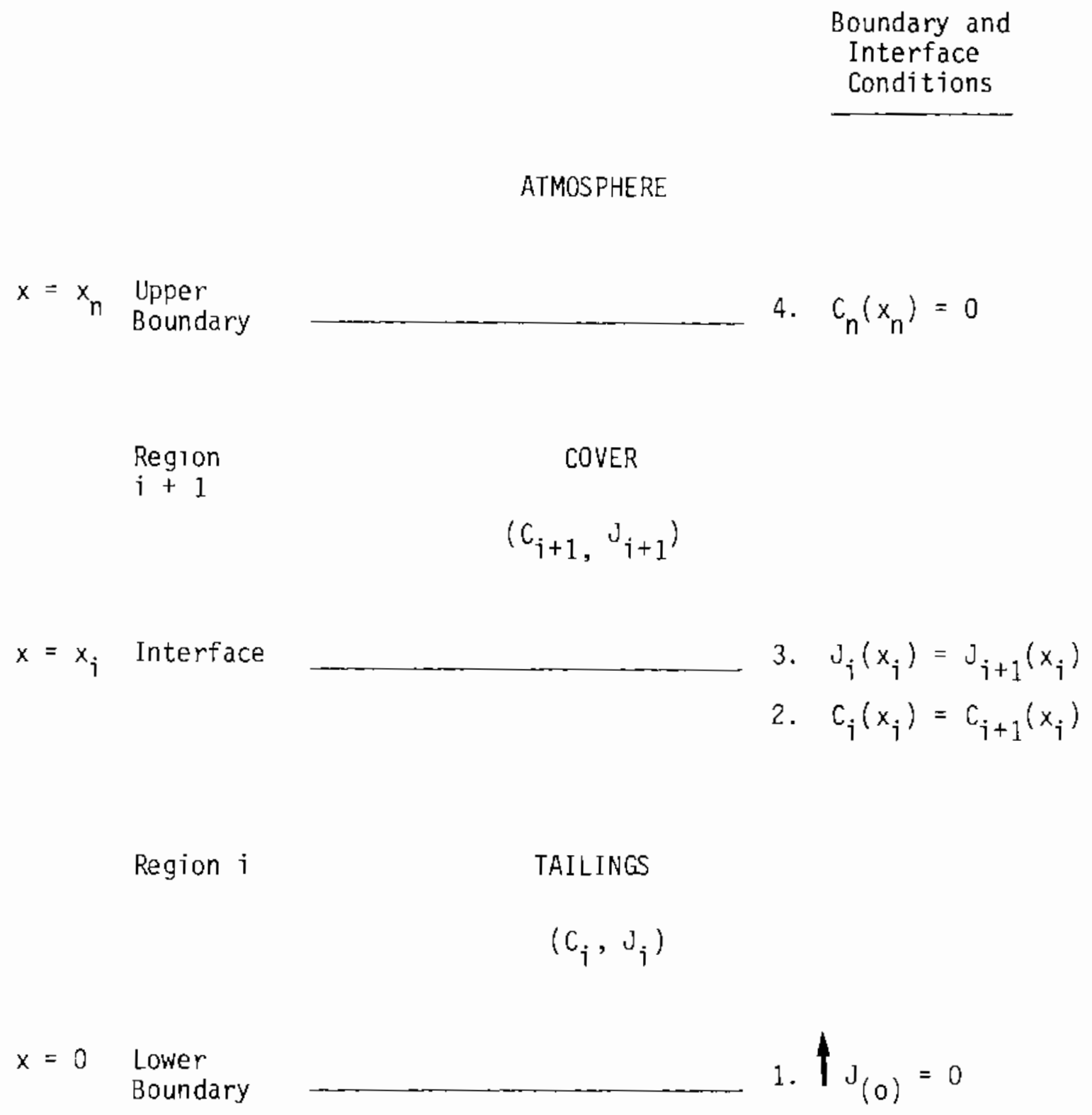

FIGURE 2.1 BOUNDARY AND INTERFACE CONDITIONS FOR SOLVING THE DIFFUSION EQUATIONS 
then

$$
C(x)=\frac{R_{b} E}{p_{0}}\left[1-\frac{\exp \left(b_{0} x\right)+\exp \left(-b_{0} x\right)}{\exp \left(b_{0} x_{0}\right)+\exp \left(-b_{0} x_{0}\right)^{3}}\right.
$$

and

$$
J(x)=\operatorname{Ro}_{b} E\left(\frac{\lambda D_{0}}{p_{0}}\right)^{\frac{1}{2}} \frac{\left[\exp \left(b_{0} x\right)-\exp \left(-b_{0} x\right)\right]}{\left[\exp \left(b_{0} x_{0}\right)+\exp \left(-b_{0} x_{0}\right)\right]}
$$

Finally, the flux at the surface of the bare tailings is given by:

$$
\begin{gathered}
J\left(x_{0}\right)=J_{0}=R_{p_{b}} E\left(\frac{\lambda D_{0}}{P_{0}}\right)^{\frac{1}{2}} \tanh \left(\sqrt{\frac{\lambda p_{0}}{D_{0}}} x_{0}\right) \\
J_{0}=b_{0} D_{0} S_{0} \tanh \left(b_{0} x_{0}\right)
\end{gathered}
$$

where, as stated previously, $D_{0}$ is the $D_{e}$ for the tailings.

\subsection{SOLUTION FOR COVERED TAILINGS}

The solution of the diffusion equation for a two-region problem applies to a tailings pile covered with a homogeneous material. For simplicity the source term in the cover is assumed to be zero, $C_{a}$ at the surface of the cover is also assumed to be zero, and the origin is assumed to be at the interface. Application of the boundary conditions yields the following set of equations: 


$$
\begin{array}{llll}
A_{0} \exp \left(-2 b_{0} x_{0}\right) & -B_{0} & & =0 \\
A_{0} & +B_{0}-A_{1}-B_{1} & =-S_{0} \\
A_{0} & -B_{0} & -A_{1}\left(\frac{D_{1} b_{1}}{D_{0} b_{0}}\right)+B_{1}\left(\frac{D_{1} b_{1}}{D_{0} b_{0}}\right) & =0 \\
A_{1} & +B_{1} \exp \left(-2 b_{1} x_{1}\right)=0
\end{array}
$$

Solution of Eqs 2-11 for $A$ and $B$ constants gives

$$
\begin{aligned}
& A_{1}=\frac{J_{0}}{b_{0} D_{0}} \frac{\tanh \left(b_{0} x_{0}\right)\left[1-\exp \left(2 b_{1} x_{1}\right)\right]-b_{1} D_{1}\left[1+\exp \left(2 b_{i} x_{i}\right)\right]}{B_{1}=-A_{1} \exp \left(2 b_{1} x_{1}\right)}
\end{aligned}
$$

Substitution of Eqs 2-12 and 2-13 into Eq 2-6 for the flux in the cover (region 1), yields:

$$
J_{1}(x)=\frac{J_{0}\left[\exp \left(b_{1} x\right)+\exp \left(2 b_{1} x_{1}-b_{1} x\right)\right]}{\left(\frac{D_{0} b_{0}}{D_{1} b_{1}}\right)\left[\exp \left(2 b_{1} x_{1}\right)-1\right] \tanh \left(b_{0} x_{0}\right)+\left[1+\exp \left(2 b_{1} x_{1}\right)\right]}
$$

where Eq 2-10 has also been utilized.

The flux at the surface of the cover is given by substituting $x=x$, into Eq 2-14.

$$
J_{1}\left(x_{1}\right)=\frac{2 J_{0} \exp \left(-b_{1} x_{1}\right)}{\left[1+\left(\frac{D_{0} b_{0}}{D_{1} b_{1}}\right) \tanh \left(b_{0} x_{0}\right)\right]+\left[1-\left(\frac{0}{D_{1} b_{1}}\right) \tanh \left(b_{0} x_{0}\right)\right] \exp \left(-2 b_{1} x_{1}\right)}
$$

It is of interest to examine the behavior of $\mathrm{J}_{1}\left(\mathrm{x}_{1}\right)$ under various conditions. For $D_{0} b_{0}$ equal to $D_{1} b_{1}$, and for sufficiently thick tailings such that 
tanh $\left(b_{0} x_{0}\right)$ is approximately unity, then Eq 2-15 becomes:

$$
\mathrm{J}_{1}\left(\mathrm{x}_{1}\right)=\mathrm{J}_{0} \exp \left(-\mathrm{b}_{1} \mathrm{x}_{1}\right)
$$

which is the simple exponential attenuation shown by curve $A$ in Figure 2.2 . However, if $\mathrm{D}_{0} \mathrm{~b}_{0}<<\mathrm{D}_{i} \mathrm{~b}_{i}$, Eq $2-15$ becomes:

$$
J_{1}\left(x_{1}\right)=\frac{2 J_{0} \exp \left(-b_{1} x_{1}\right)}{1+\exp \left(-2 b_{1} x_{1}\right)}
$$

For small $x_{1}$, the value of $J_{1}\left(x_{1}\right)$ is approximately equal to $J_{0}$ as shown by curve $B$ in Fiqure 2.2, before the cover flux begins to decrease. This effect has been observed in laboratory measurements of radon fluxes from covered tailings. (20) At large $x_{1}$, Eq 2-17 becomes:

$$
\mathrm{J}_{1}\left(\mathrm{x}_{1} \text { large }\right)=2 \mathrm{~J}_{0} \exp \left(-\mathrm{b}_{1} \mathrm{x}_{1}\right)
$$

so that $J_{1}$ decreases exponentially in the same manner as in Eq 2-16 but retains twice the magnitude which is shown by curve B in Figure 2.2. This is also observable $\mathrm{e}^{(20)}$ in 1 aboratory measurements.

\subsection{MULTIREGION SOLUTION}

The mathematical solutions for three ${ }^{(9)}$ and four ${ }^{(36)}$ region systems have been presented previously. The diffusion solutions for the radon concentration and flux in a general multiregion system have recently been developed. The following presentation is based upon Reference 37.

\subsubsection{General Multilayer Expression}

The configuration and coordinate system used in the present development 


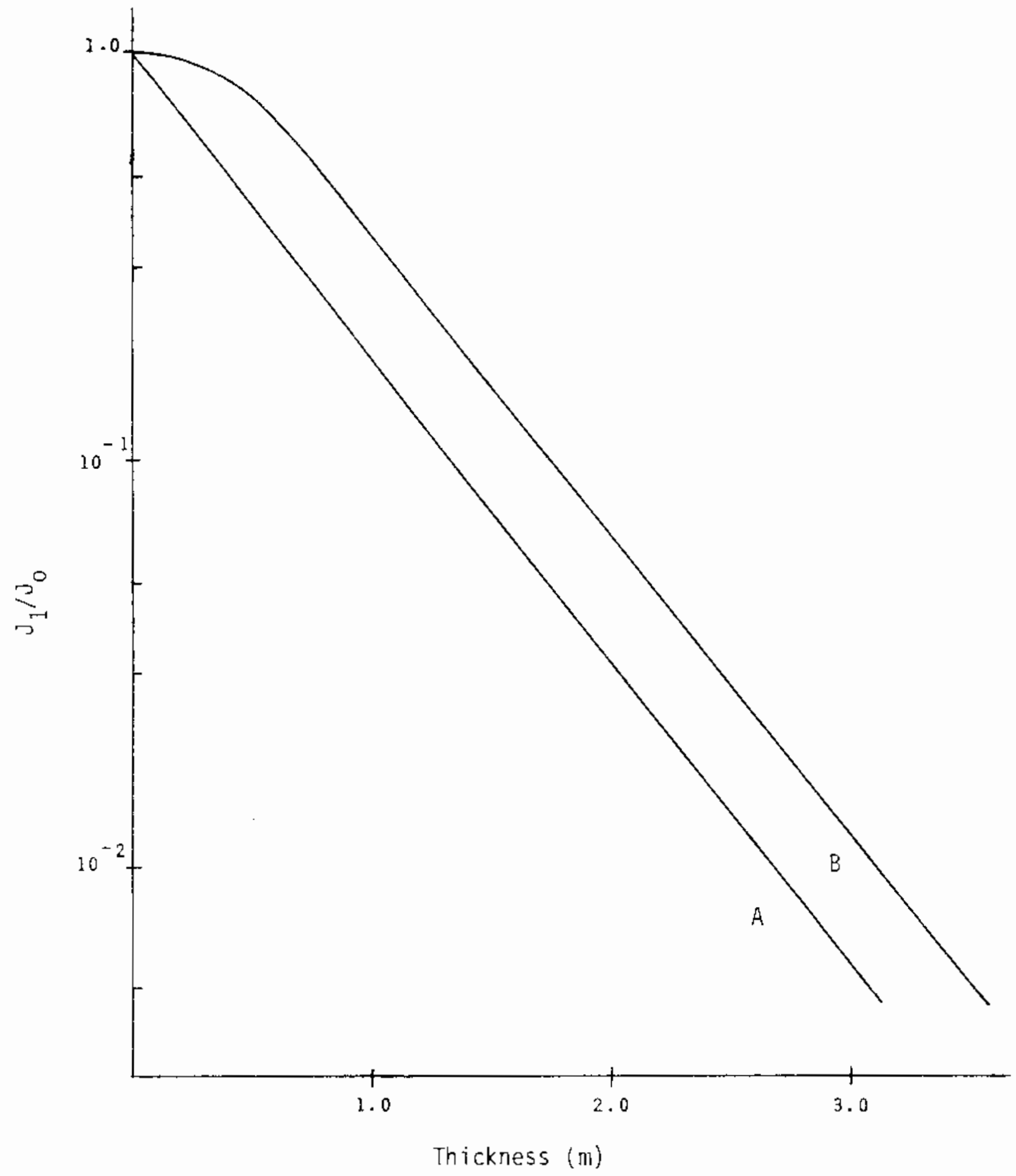

FIGURE 2.2 COVER SURFACE RADON FLUX FOR VARIOUS

THICKNESSES AND PARAMETERS

Curve $A\left(D_{0} b_{0}=D_{1} b_{1}\right)$

Curve $B\left(D_{0} b_{0}<<D_{1} b_{1}\right)$ 
of radon transport through a multilayer system is given in Figure 2.3. With each of the Jayers in the system is associated a thickness, $d_{i}$, a diffusion coefficient, $D_{j}$, and air-filled porosity, $p_{i}$, and a radon source, $Q_{i}$.

The general solution of Eq 2-1 for the radon concentration in the interval $x_{i-1} \leqslant x \leqslant x_{i}$, as given by Eq $2-4$, is repeated with the present nomenclature,

$$
c_{i}(x)=A_{i} \exp \left(b_{i} x\right)+B_{i} \exp \left(-b_{i} x\right)+S_{i}
$$

for

$$
x_{i-1} \leqslant x \leqslant x_{i}, i=1 \text { to } n
$$

and

$$
x_{i}=x_{i-1}+d_{i}
$$

where

$$
\begin{array}{ll}
C_{i}(x)= & \text { radon concentration at } x \text { in the } i^{\text {th }} \text { layer } \\
x & =\text { the vertical distance from the bottom of } \\
& \text { the tailings system } \\
b_{i}= & \left(p_{i} \lambda / D_{i}\right)^{\frac{1}{2}} \\
d_{i}= & \text { layer thickness } \\
D_{i}= & \text { the average effective radon diffusion coefficient }\left(D_{e}\right) \\
& \text { within the } i \text { th layer } \\
p_{i}= & \text { the average total porosity within the } i \text { th layer } \\
Q_{i}= & \text { the average volumetric }{ }^{222} \text { Rn source within } \\
& \text { the } i^{\text {th layer }} \\
S_{i} \quad= & Q_{i} / p_{i} \lambda
\end{array}
$$

The associated radon flux $J_{i}$, is given by Eq 2-6 and is repeated here: 

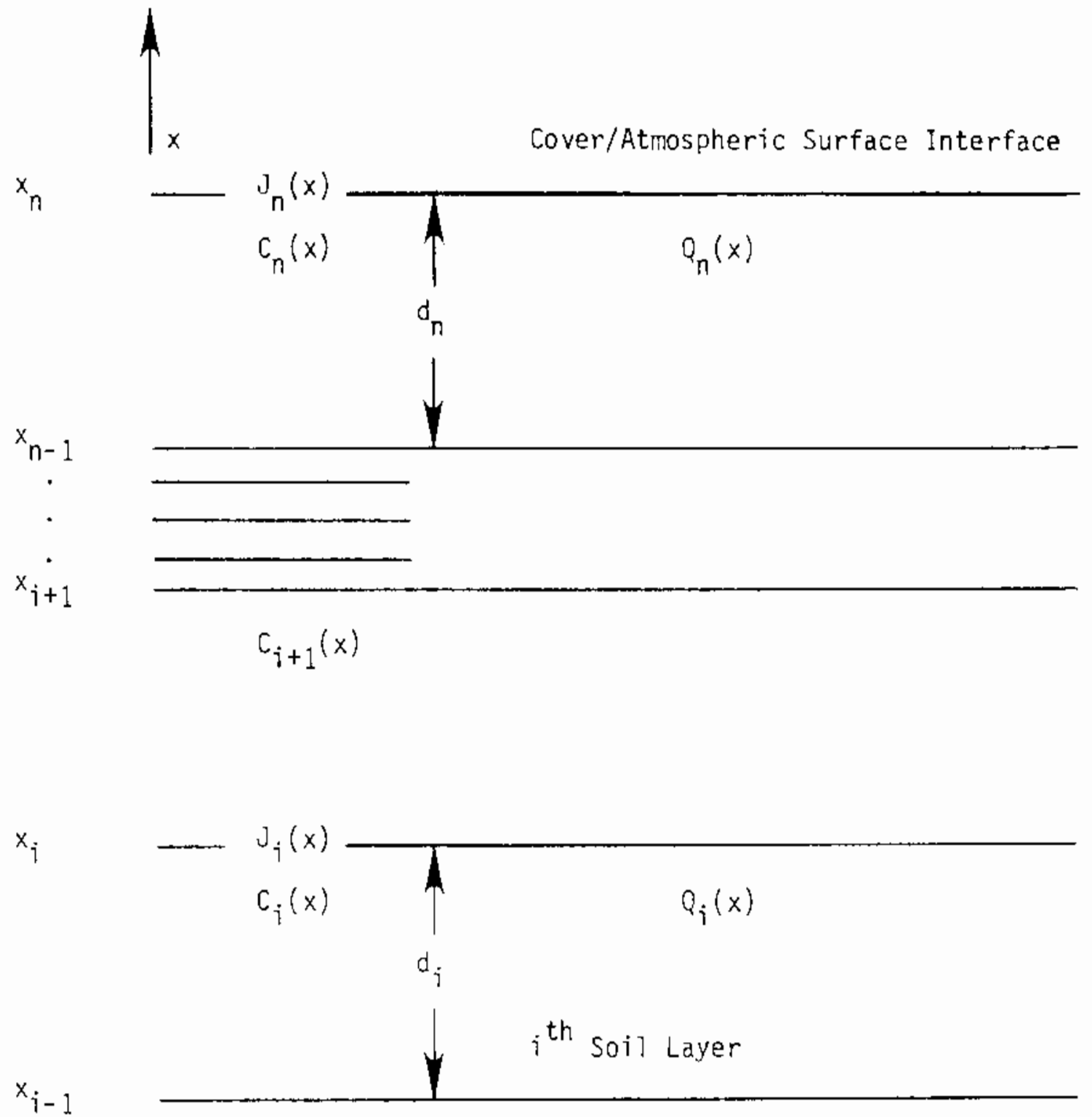

FIGURE 2.3 MULTILAYERED TAILINGS-COVER SYSTEM 


$$
J_{i}(x)=-D_{i} b_{i}\left[A_{j} \exp \left(h_{i} x\right)-B_{i} \exp \left(-b_{i} x\right)\right]
$$

The $A_{i}$ and $B_{i}$ constants are determined by the boundary conditions for each layer.

As boundary conditions for each layer, the concentration, $C(x)$, and flux, $J(x)$, are assumed to be continuous across the layer interface as before, so that

$$
\begin{gathered}
C_{j}\left(x_{i}\right)=C_{i+1}\left(x_{j}\right) \\
-D_{i} \frac{d C_{i}\left(x_{i}\right)}{d x}=-D_{i+1} \frac{d C_{i+1}\left(x_{i}\right)}{d x}
\end{gathered}
$$

for $i=1,2, \ldots n-1$.

At the bottom boundary of the tailings system (i.e., $x_{0}=0$ ) it is assumed that the radon flux is a known constant, $J_{0}$, where

$$
-D_{1} \frac{d C_{1}(0)}{d x}=J_{0}
$$

and at the top boundary of the tailings system (i.e., $x_{n}$ at the soil-air interface) it is assumed that the radon concentration is a known constant where,

$$
c_{n}\left(x_{n}\right)=c_{a}
$$

Imposing the boundary conditions as defined by Eq 2-21 upon Eq 2-19 provides the following relation for continuity of the concentration at the $x=x_{i}$ interface:

$A_{i} \exp \left(b_{i} x_{j}\right)+B_{i} \exp \left(-b_{i} x_{i}\right)+S_{i}=A_{i+1} \exp \left(b_{i+1} x_{i}\right)+B_{i+1} \exp \left(-b_{i+1} x_{i}\right)+s_{i+1}$ 
Equation 2-22 imposed upon Eq 2-20 requires, for flux continuity at the same interface $\left(x=x_{i}\right)$, that

$$
\begin{gathered}
-D_{i} b_{i}\left[A_{i} \exp \left(b_{i} x_{i}\right)-B_{i} \exp \left(-b_{i} x_{j}\right)\right]= \\
-D_{i+1} b_{i+1}\left[A_{i+1} \exp \left(b_{i+1} x_{i}\right)-B_{i+1} \exp \left(-b_{i+1} x_{i}\right)\right]
\end{gathered}
$$

Equation 2-23 imposed upon 2-20 provides the following condition for the flux at the bottom layer:

$$
A_{1}=B_{1}-J_{0} /\left(D_{1} b_{1}\right)
$$

Finally, Eq 2-24 imposed upon Eq 2-19 gives the following condition for radon concentration at the soil-air surface:

$$
A_{n} \exp \left(b_{n} x_{n}\right)+B_{n} \exp \left(-b_{n} x_{n}\right)+S_{n}=C_{a}
$$

Equations 2-25 through 2-28 constitute a complete set of equations for determining the constants, $A_{j}$ and $B_{i}$. An equivalent matrix equation for this system of equations is shown in Figure 2.4.

The matrix equation representing the system of equations in Figure 2.4 has the general form:

$$
M X=N
$$

which has the solution,

$$
X=M^{-1} N
$$

where $M^{-1}$ is the inverse of the coefficient matrix $M$. However, the determination of the inverse of this coefficient matrix is usually cumbersome, time consuming and subject to computational round-off errors. A simpler solution 


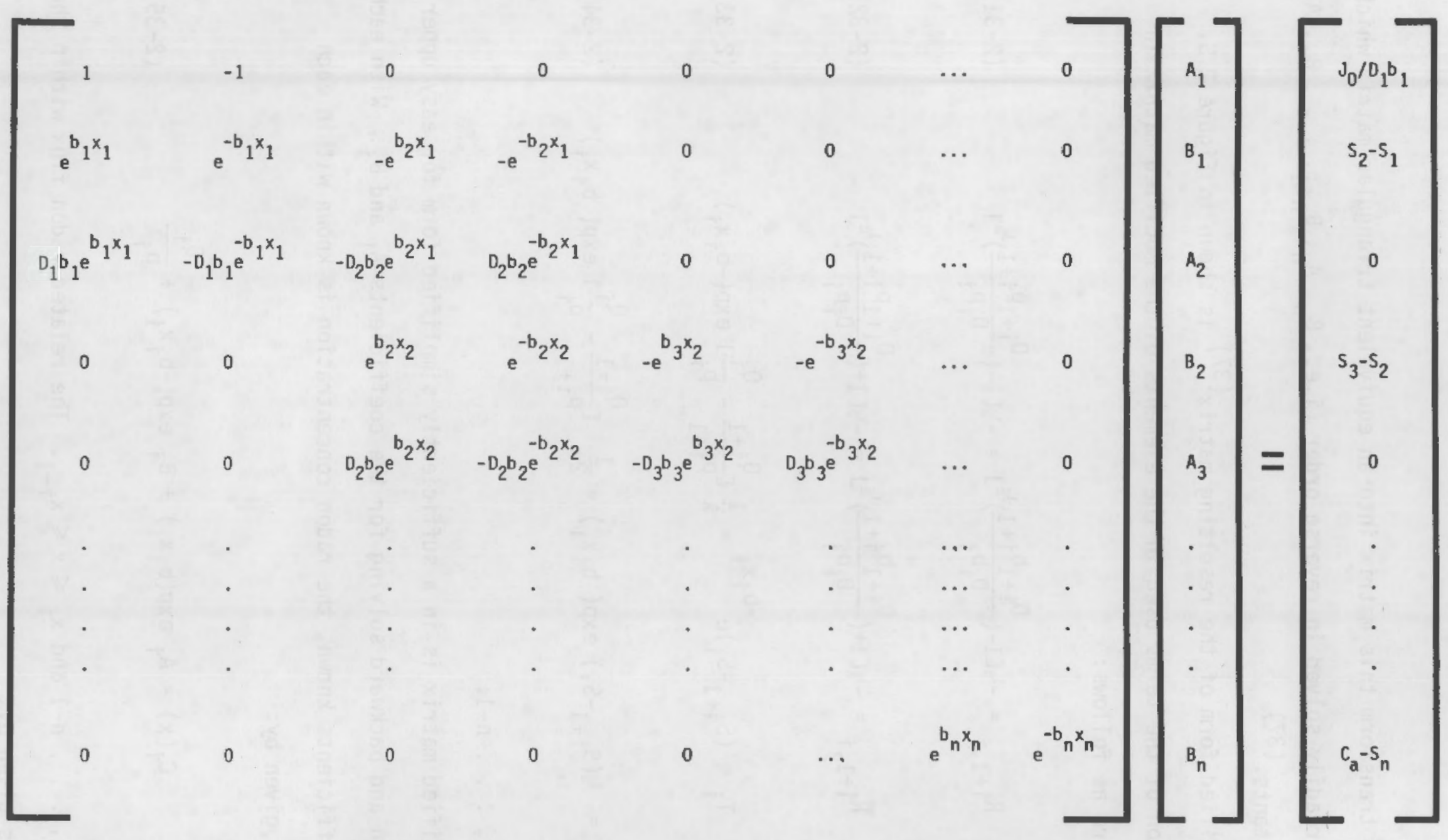

FIGURE 2.4 MATRIX REPRESENTATION OF EQUATIONS FOR DETERMINING THE CONSTANTS $A_{i}$ AND $B_{i}$ 
scheme is to transform this matrix into an equivalent triangular matrix which can then be readily solved in reverse order (i.e., $B_{n}, A_{n}, B_{n-1}, \ldots B_{1}, A_{1}$ ) for the constants. (37)

The modified form of the resulting matrix ${ }^{(37)}$ is shown in Figure 2.5 . The definition of the terms used in the elements of the modified matrix in Figure 2.5 are as follows:

$$
\begin{gathered}
R_{i+1, i}=-\frac{1}{2}\left[1-\left(\frac{D_{i+1} b_{i+1}}{D_{i} b_{i}}\right)^{\frac{1}{2}}\right]=-\frac{1}{2}\left[1-\left(\frac{D_{i+1} p_{j+1}}{D_{i} P_{i}}\right)^{\frac{1}{2}}\right] \\
\bar{R}_{i+1, i}=-\frac{1}{2}\left[1+\left(\frac{D_{i+1} b_{i+1}}{D_{i} b_{i}}\right)^{\frac{1}{2}}\right]=-\frac{1}{2}\left[1+\left(\frac{D_{i+1} P_{i+1}}{D_{i} p_{i}}\right)^{\frac{1}{2}}\right] \\
T_{i}=\left(S_{i+1}-S_{i}\right) e^{-b_{i} x_{i}}=\frac{1}{\lambda}\left[\frac{Q_{i+1}}{p_{i+1}}-\frac{Q_{i}}{P_{i}}\right] \exp \left(-b_{j} x_{i}\right) \\
U_{i}=\frac{1}{2}\left(S_{i+1}-S_{i}\right) \exp \left(b_{i} x_{i}\right)=\frac{1}{2 \lambda}\left[\frac{Q_{j+1}}{P_{j+1}}-\frac{Q_{i}}{P_{i}}\right] \exp \left(b_{i} x_{i}\right)
\end{gathered}
$$

for $i=1,2, \ldots n-1$.

The modified matrix is in a sufficiently simplified form for easy upper triangulation and backward solving for the coefficients $A_{i}$ and $B_{i}$. With each of these coefficients known, the radon concentration is known within each layer and is given by:

$$
C_{j}(x)=A_{i} \exp \left(b_{j} x_{i}\right)+B_{i} \exp \left(-b_{i} x_{j}\right)+\frac{Q_{j}}{p_{j} \lambda}
$$

for $i=1,2, \ldots n-1$ and $x_{i} \leqslant x \leqslant x_{i+1}$. The related radon flux with in that same layer is given by: 


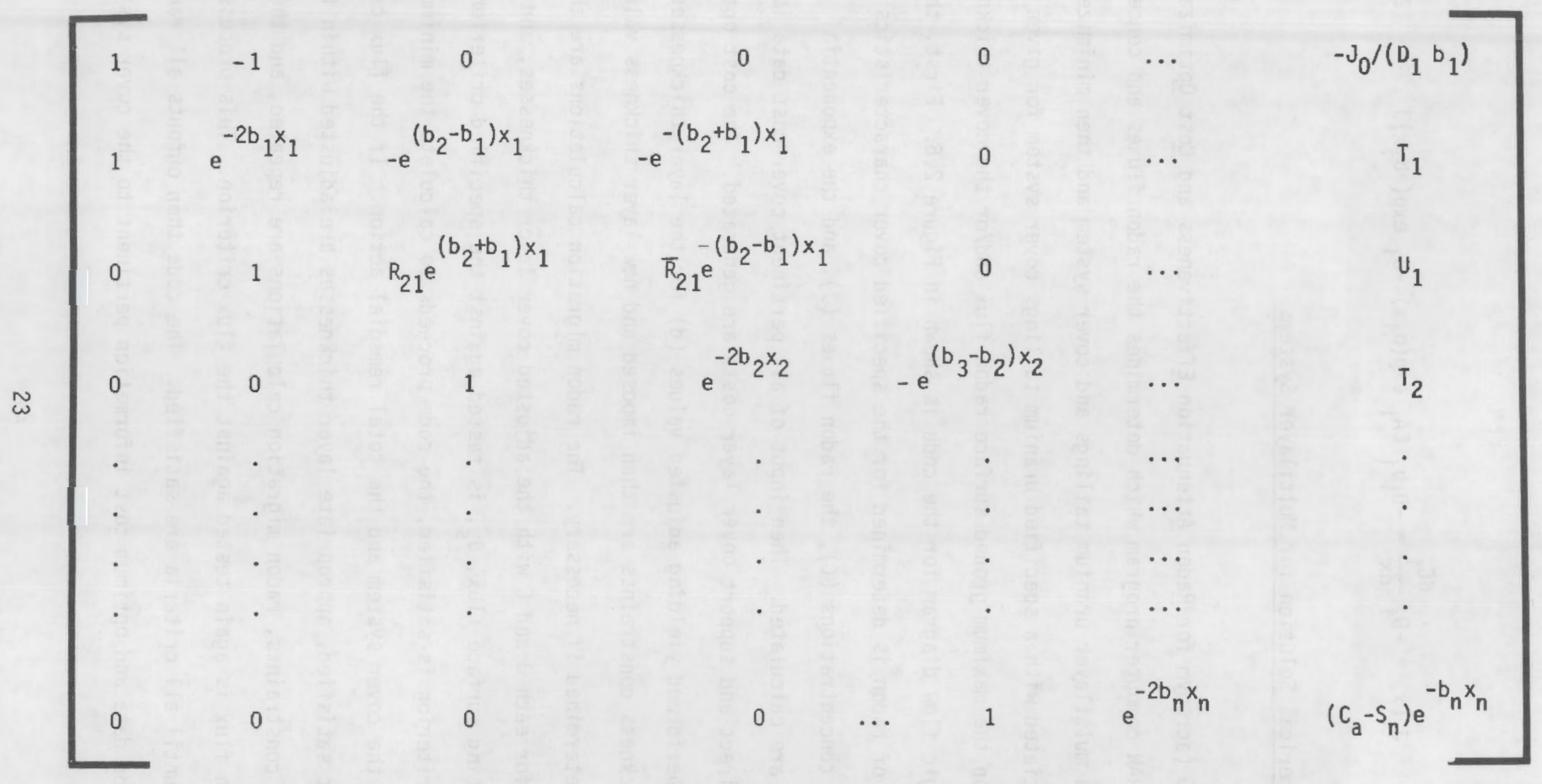




$$
J_{i}(x)=-D_{i} \frac{d C_{i}}{d x}=-D_{j} b_{i}\left[A_{i} \exp \left(b_{i} x\right)-B_{i} \exp \left(-b_{i} x\right)\right]
$$

\subsubsection{Numerical Solution for Multilayer Systems}

RAECO (acronym for Radon Attenuation Effectiveness and Cost Optimization) is a FORTRAN computer program which determines the radon fluxes and concentrations in a multilayer uranium tailings and cover system and then minimizes the cost associated with a specified uranium tailings cover system for given constraints on the maximum ground surface radon flux and/or the cover thickness.

A logic flow diagram for the code is shown in Figure 2.6. First, the migration of radon is determined for the specified cover characteristics and the radon concentrations $(C)$, the radon fluxes $(\mathrm{J})$, and the exponential constants are calculated. Then input of a11 pertinent cover cost data is made and the direct and support cover layer costs are generated. The cost optimization is performed yielding adjusted values (d) for the layer thicknesses. Layer thickness constraints are then imposed and new layer thickness values (d) are determined if necessary. The radon migration calculations are then repeated for each $\mathrm{J}$ and $\mathrm{C}$ with the adjusted cover layer thicknesses, and the resulting surface flux, $J_{S}$, is tested against the specified criterion, $J_{C}$. If this criterion is satisfied, the code proceeds to calculate the minimum costs for the cover system and the total remedial action. If the flux criterion is not satisfied, appropriate layer thicknesses are adjusted within the specified constraints, radon migration calculations are repeated, and the surface radon flux is again tested against the flux criterion. This process is repeated until all criteria are satisfied. The code then outputs all radon attenuation data and optimum cost information pertinent to the cover system 


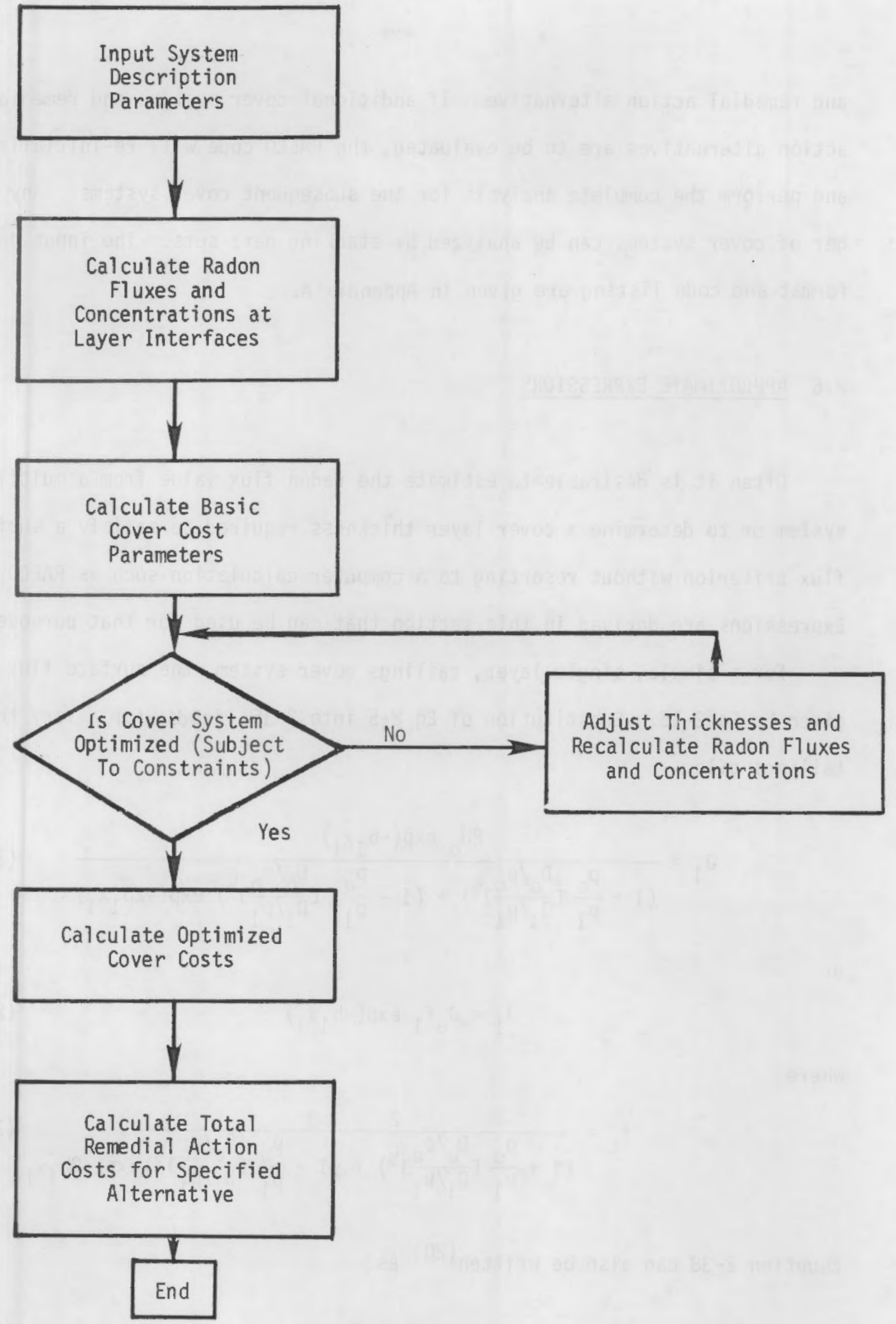


and remedial action alternative. If additional cover systems and remedial action alternatives are to be evaluated, the RAECO code will re-initialize and perform the complete analys is for the subsequent cover systems. Any number of cover systems can be analyzed by stacking data sets. The input data format and code listing are given in Appendix A.

\subsection{APPROXIMATE EXPRESSIONS}

Often it is desirable to estimate the radon flux value from a multilayer system or to determine a cover layer thickness required to satisfy a surface flux criterion without resorting to a computer calculation such as RAECO. Expressions are derived in this section that can be used for that purpose.

For a simple, single-layer, tailings cover system, the surface flux is given by Eq 2-15. Substitution of Eq 2-5 into 2-15 yields, for a very thick tailings pile,

$$
J_{1}=\frac{2 J_{0} \exp \left(-b_{1} x_{1}\right)}{\left(1+\frac{P_{0}}{p_{1}}\left[\frac{D_{0} / p_{0}}{D_{1} / p_{1}}\right]^{\frac{1}{2}}\right)+\left(1-\frac{P_{0}}{p_{1}}\left[\frac{D_{0} / p_{0}}{D_{1} / p_{1}}\right]^{\frac{1}{2}}\right) \exp \left(-2 b_{1} x_{1}\right)}
$$

or

$$
J_{1}=J_{0} f_{1} \exp \left(-b_{1} x_{1}\right)
$$

where

$$
f_{1}=\frac{2}{\left(1+\frac{P_{0}}{P_{1}}\left[\frac{D_{0} / p_{0}}{D_{1} / p_{1}}\right]^{\frac{1}{2}}\right)+\left(1-\frac{p_{0}}{p_{1}}\left[\frac{D_{0} / P_{0}}{D_{1} / p_{1}}\right]^{\frac{1}{2}}\right) \exp \left(-2 b_{1} x_{1}\right)}
$$

Equation $2-38$ can also be written ${ }^{(20)}$ as:

$$
J_{1}=J_{0} \exp \left(-a_{1} x_{1}\right)
$$


Where

$$
a_{1}=b_{1} / \sqrt{h}=\sqrt{\frac{\lambda p_{1}}{D_{1} h}}
$$

Comparison of Eqs 2-38 and 2-41 gives the following relationship for $h$ :

$$
h=\left[1-\frac{1}{b_{1} x_{1}} \ln f\right]^{-2}
$$

Although $h$ is generally a function of $x$, and the tailings and cover parameters, it can often be approximated by a constant average value because $h$ is a very slowly varying function of the cover thickness and it approaches unity as the cover thickness becomes large.

Often the allowable surface flux is specified and it is the cover thickness that needs to be determined. The value of $x_{1}$ for a specified flux can be obtained by rearranging Eq 2-37 as follows:

$x_{1}=\sqrt{\frac{D_{1}}{p_{1} \lambda}}\left[\ln \left(\frac{2 J_{0}}{J_{1}}\right)-\ln \left[\left(1+\frac{P_{0}}{P_{1}}\left[\frac{D_{0} / p_{0}}{D_{1} / p_{1}}\right]^{\frac{1}{2}}\right)+\left(1-\frac{P_{0}}{P_{1}}\left[\frac{D_{0} / p_{0}}{D_{1} / p_{1}^{\frac{1}{2}}}\right) \exp \left(-2 b_{1} x_{1}\right)\right)\right]\right]$

Most covers of interest exhibit a high degree of attenuation so that the last term in the second natural logarithm is very small. To a high degree of accuracy, the term $\exp \left(-2 b_{1} x_{1}\right)$ may be replaced by $\left(J_{1} / J_{0}\right)^{2}$, so that Eq $2-43$ becomes :

$x_{1}=\sqrt{\frac{D_{1}}{p_{1}^{\lambda}}}\left[\ln \left(\frac{2 J_{0}}{J_{1}}\right)-\ln \left[\left(1+\frac{P_{0}}{p_{1}}\left[\frac{D_{0} / p_{0}}{D_{1} / p_{1}}\right]^{\frac{1}{2}}\right)+\left(1-\frac{p_{0}}{p_{1}}\left[\frac{D_{0} / p_{0}}{D_{1} / p_{1}}\right]^{\frac{1}{2}}\right)\left(\frac{J_{1}}{J_{0}}\right)^{2}\right]\right]$ 
Often the diffusion coefficients for a proposed tailings and cover system are not known. For the purpose of estimating a cover thickness, Eqs 1-1 or 1-2 can be used to approximate the diffusion coefficients. If Eq 1-1 is used, then Eq 2-44 becomes:

$$
\begin{aligned}
x_{1}=2.28 \exp \left(-0.13 M_{1}\right)\left\{\ln \left(\frac{2 J_{0}}{J_{1}}\right)-\ln \left[\left(1+\frac{p_{0}}{p_{1}} \exp \left(0.13\left(M_{1}-M_{0}\right)\right)\right)\right.\right. \\
\left.\left.+\left(1-\frac{p_{0}}{p_{1}} \exp \left(0.13\left(M_{1}-M_{0}\right)\right)\right)\left(\frac{J_{1}}{J_{0}}\right)^{2}\right]\right\}
\end{aligned}
$$

where

$$
\begin{aligned}
& M_{0}=\text { weight-percentage of moisture in tailings } \\
& M_{1}=\text { weight-percentage of moisture in soil cover }
\end{aligned}
$$

If the flux attenuation is greater than a factor of ten $\left(J_{0} / J_{1}>10\right)$, Eq $2-45$ can be written as,

$$
x_{1}=2.28 \exp \left(-0.13 M_{1}\right)\left[\ln \left(2 J_{0} / J_{1}\right)-\ln \left[1+\frac{p_{0}}{p_{1}} \exp \left(0.13\left(M_{1}-M_{0}\right)\right)\right]\right]
$$

For calculations involving composite covers, an approximate expression can be obtained from the following considerations. The general expressions for the flux in the $i^{\text {th }}$ and $i-1^{\text {th }}$ cover layers are given by:

$$
\begin{aligned}
J_{i} & =J\left(x_{i}\right)=-D_{i} b_{i}\left[A_{i} \exp \left(b_{i} x_{i}\right)-B_{i} \exp \left(-b_{i} x_{i}\right)\right] \\
J_{i-1} & =J\left(x_{i-1}\right)=-D_{i} b_{i}\left[A_{i} \exp \left(b_{i} x_{i-1}\right)-B_{i} \exp \left(-b_{i} x_{i-1}\right)\right]
\end{aligned}
$$


It should be noted that for $i=1, J_{i-1}$ is not equal to the bare flux expression $\mathrm{J}_{0}$.

Forming the ratio $\mathrm{J}_{i} / \mathrm{J}_{i-1}$ yields

$$
\frac{J_{i}}{J_{i-1}}=f_{i} \exp \left(-b_{i} d_{i}\right)
$$

where

$$
\begin{gathered}
f_{i} \frac{\left.A_{i} / B_{i}\right) \exp \left({ }^{\left.2 b_{i} x_{i}\right)-1}\right.}{\left(A_{i} / B_{i}\right) \exp \left(2 b_{i} x_{i-1}\right)-1} \quad i \geqslant 2 \\
d_{i}=x_{i}-x_{i-1}
\end{gathered}
$$

Taking the product of Eq 2-47 for $i=2$ to $n$ gives

$$
\frac{J_{n}}{J_{1}}=\left(\prod_{i=2}^{n} f_{i}\right) \exp \left(-\sum_{i=2}^{n} b_{i} d_{i}\right)
$$

Now, $\mathrm{J}_{1}$ can be expressed in the following form

$$
J_{1}=J_{0} f_{1} \exp \left(-b_{1} d_{1}\right)
$$

where

$$
f_{1}=-D_{1} b_{1} A_{1}\left[\left(A_{1} / B_{1}\right)-1\right]
$$

so that Eq 2-49 becomes:

$$
J_{n}=J_{0}\left(\prod_{i=1}^{n} f_{i}\right) \exp \left(-\sum_{i=1}^{n} b_{i} d_{i}\right)
$$


where $f_{j}$ is defined in Eqs 2-48 and 2-51.

Equation $2-52$ is readily transformed to

$$
J_{n}=J_{0} \prod_{i=1}^{n} \exp \left(-a_{i} d_{i}\right)
$$

where

$$
\begin{gathered}
a_{i}=b_{i} / \sqrt{h_{i}} \\
h_{i}=\left[1-\frac{1}{b_{i} d_{i}} \ln f_{i}\right]^{-2}
\end{gathered}
$$

Equations 2-52 and 2-53 define the radon flux for the $n^{\text {th }}$ layer exactly, assuming only the absence of radium in the cover layers and the usual boundary conditions. However, to use these equations in their present form requires some additional information about the parameters $A_{i}$ and $B_{i}$. If these are known, then $A_{n}$ and $B_{n}$ can be used directly in Eq 2-20 to obtain $J_{n}$. The purpose of obtaining Eqs 2-52 and 2-53 is to demonstrate the attenuation provided by a multiple-layer cover system can be expressed in the form of the product of the attenuations for each layer. Thus, the flux $\mathrm{J}_{\mathrm{m}}$ can be approximated from the surface flux from an m-1 cover layer system by:

$$
J_{m}=J_{m-1} \exp \left(-a_{m} x_{m}\right)
$$

This approach treats the system as an effective source layer, consisting of the tailings and the $m-1$ cover layers; and the top one-layer cover, the $m^{\text {th }}$ layer. With this approximation either Eq 2-38 or 2-40 can be used to obtain the surface flux. However, the appropriate value of $D / p$ for the effective source must be determined. The influence is assumed to be proportional to the attenuation 
through the succeeding layers. Furthermore, the direct influence of the $i^{\text {th }}$ layer upon the attenuation in the $m^{\text {th }}$ layer is assumed to be of the form $\left[1-\exp \left(-a_{i} d_{j}\right)\right]$, so that the contribution $D_{j} / p_{i}$ to the corresponding parameter $D_{s m} / p_{s m}$ in the effective source is

$$
\frac{D_{i}}{p_{i}}\left[1-\exp \left(-a_{i} d_{i}\right)\right] \exp \left(-\sum_{j=i+1}^{m-1} a_{j} d_{j}\right)
$$

Summing over all layers up to $m-1$ yields:

$$
\frac{D_{s m}}{p_{s m}}=\sum_{i=0}^{m-1} \frac{D_{i}}{P_{i}}\left[1-\exp \left(-a_{i} d_{i}\right)\right] \exp \left(-\sum_{j=i+1}^{m-1} a_{j} d_{j}\right)
$$

This expression is exact in when all $\mathrm{D}_{\mathfrak{i}} / \mathrm{p}_{\mathfrak{j}}$ are equal. Additionally, the parameter $a_{j}$ can be replaced by $b_{i}$ with little loss of accuracy. With these definitions, Eqs 2-38 and 2-41 become

$$
\begin{gathered}
J_{m}=J_{m-1} f_{m} \exp \left(-b_{m} d_{m}\right) \\
f_{m}=\frac{2}{\left[1+\left(\frac{D_{s m} / P_{s m}}{D_{m} / P_{m}}\right)^{\frac{1}{2}}\right]+\left[1-\left(\frac{D_{s m} / P_{s m}}{D_{m} / P_{m}}\right)^{\frac{1}{2}}\right] \exp \left(-2 b_{m} x_{m}\right)} \\
J_{m}=J_{m-1} \exp \left(-a_{m} d_{m}\right) \\
a_{m}=b_{m} / \sqrt{h_{m}}=b_{m}\left(1-\frac{\ell_{m}}{b_{m} d_{m}}\right)
\end{gathered}
$$


In order to determine $\mathrm{J}_{\mathrm{m}}$ to a high degree of accuracy, $\mathrm{J}_{\mathrm{m}-1}$ must be known. Equation 2-56 or 2-58 can be used to obtain $\mathrm{J}_{\mathrm{m}-1}$ in a similar manner. Therefore, the most appropriate use of the above equations is to determine $\mathrm{D}_{\mathrm{S} 2} / \mathrm{P}_{\mathrm{S} 2}$ and $\mathrm{J}_{2}$, then, using $\mathrm{J}_{2}$, obtain $\mathrm{D}_{\mathrm{S}_{3}} / \mathrm{P}_{\mathrm{S} 3}$ and $\mathrm{J}_{3}$, and so on until $\mathrm{J}_{\mathrm{B}}$ is calculated. This procedure is demonstrated by an example given in Section 3.4. 


\section{APPLICATION OF CALCULATION METHODS}

The procedures for determining the cover thickness required over uranium mill tailings to meet flux criteria are presented in this chapter. Briefly, the major items are as follows:

1. Definition of Source Term - determine the values of parameters defining the radon generation and diffusion out of the tailings.

2. Cover Materials Characterization - select candidate cover materials and estimate their porosities, moisture characteristics and diffusion coefficients.

3. Initial System Configuration - establish an initial cover design for analysis. For single-layer systems, provisions are made for determining the cover thickness.

4. System Cover Surface Flux and Thickness Determination perform radon flux calculations and adjust cover system design as necessary.

\section{1 SOURCE TERM DEFINITION}

Characterization of the source term is the first major step in performing the design analysis of an adequate cover system. As given by Eq 2-2 or 2-45, the key parameters for the source term are the radium concentration, the dry bulk density and the emanating power.

Values for the radium concentration, $R$, of tailings can be measured directly from tailings samples by the radon equilibrium method, by direct gamma spectroscopy, or by chemical separations and subsequent alpha spectroscopy. If a radium analysis is not available, it can be estimated quite accurately from the uranium concentration of the ore as specified by the ore grade, using 
the following equation:

$$
R=K_{a} G
$$

where

$$
\begin{aligned}
& G=\text { ore grade }\left(w t \% U_{3} O_{8}\right) \\
& K_{a}=2800 \mathrm{pCi}\left({ }^{226} \mathrm{Ra}\right) \text { per gram soi } 1 /\left(w t \% U_{3} 0_{8}\right)
\end{aligned}
$$

This equation presumes equilibrium between the uranium and radium in the ore and all radium being contained in the tailings.

The bulk density, $\rho_{b}$, of the solid tailings material is a relatively easy measurement to perform. In the absence of measured data a typical value of $1.6 \mathrm{~g} / \mathrm{cm}^{3}$ can be used for the bulk dry density.

The emanating power, E, for uranium tailings is the fraction of the radon generated that is free to diffuse in the pore spaces. It has been shown recent$1 y^{(38)}$ that $E$ varies with moisture. However, for most practical applications $(20)$ with uranium tailings, a value of 0.2 is a good estimate of $E$.

\subsection{DIFFUSION COEFFICIENTS}

If Eq 2-3 is divided by the porosity, $p$, it can be viewed as a rate balance per volume of pore space instead of a volume of material space; accordingly, the parameter $\mathrm{D}_{\mathrm{e}} / \mathrm{p}$, is the diffusion coefficient of the fluid in the pore space. When presenting values for the diffusion coefficient, the $D_{e} / p$ is often used. $(8,20)$ A tabulation of several values of $D_{e} / P$ is given in Table 3.1. In general, $D_{e} / p$ decreases dramatically with the moisture content of the diffusing medium. One correlation indicating this decrease is given in Eq 1-1. The correlation, and the data 
TABLE 3.1

BULK DIFFUSION COEFFICIENTS FOR RADON IN VARIOUS MEDIA

\begin{tabular}{|c|c|c|c|c|}
\hline \multicolumn{2}{|l|}{ Medium } & $\begin{array}{c}\text { Moisture } \\
\text { Content } \\
(\%) \\
\end{array}$ & $\begin{array}{c}D_{e} / p \\
\left(\mathrm{~cm}^{2} \mathrm{sec}\right) \\
\end{array}$ & Source \\
\hline \multicolumn{2}{|l|}{$\begin{array}{l}\text { Air } \\
\text { Water }\end{array}$} & 0 & $1.0 \mathrm{E}-1$ & $\operatorname{Ref} 8$ \\
\hline & 100 & $1.1 \mathrm{E}-5$ & $\begin{array}{ll}\operatorname{Ref} & 8 \\
\operatorname{Ref} & 8\end{array}$ \\
\hline \multicolumn{2}{|c|}{ Building Sand } & 4 & $5.4 \mathrm{E}-2$ & \\
\hline \multirow{2}{*}{\multicolumn{2}{|c|}{$\begin{array}{l}\text { Fine Quartz } \\
\text { Fine Quartz }\end{array}$}} & 0 & $6.8 \mathrm{E}-2$ & \\
\hline & & 8.1 & $5.0 \mathrm{E}-2$ & \\
\hline \multicolumn{2}{|c|}{ Fine Quartz } & 17 & $5.0 \mathrm{E}-3$ & \\
\hline \multicolumn{2}{|c|}{ ils } & & $4.5 E-2$ & Ret \\
\hline \multicolumn{2}{|c|}{$\begin{array}{l}\text { Granodiorite } \\
\text { Yucca Flats }\end{array}$} & & $3.6 \mathrm{E}-2$ & \\
\hline \multicolumn{2}{|c|}{ Granite } & & $1.5 \mathrm{E}-2$ & \\
\hline \multicolumn{2}{|c|}{$\begin{array}{l}\text { Loams } \\
\text { Varved Clays }\end{array}$} & & $8.0 \mathrm{E}-3$ & \\
\hline & 37.2 & $\begin{array}{l}1.0 \mathrm{E}-3 \\
5.7 \mathrm{E}-6\end{array}$ & \\
\hline \multirow[t]{5}{*}{ Powder River } & $\# 1$ & 5 & $2.3 \mathrm{E}-2$ & Ref $: 0$ \\
\hline & \#1 & 9 & $2.2 \mathrm{E}-2$ & \\
\hline & $\# 1$ & 17 & $2.6 \mathrm{E}-4$ & \\
\hline & \#1 & 30 & $8.2 \mathrm{E}-5$ & \\
\hline & \#2 & $\begin{array}{l}6 \\
6\end{array}$ & $\begin{array}{l}2.7 \mathrm{E}-2 \\
2.3 \mathrm{E}-2\end{array}$ & \\
\hline \multirow{4}{*}{ Shirley Basin } & \#1 & 5 & $9.3 \mathrm{E}-3$ & $\operatorname{Ref} 20$ \\
\hline & \#1 & 12 & $1.8 \mathrm{E}-2$ & \\
\hline & \#1 & 20 & $1.7 \mathrm{E}-4$ & \\
\hline & 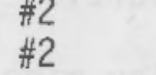 & $\begin{array}{r}8 \\
15\end{array}$ & $\begin{array}{l}2.3 \mathrm{E}-2 \\
4.6 \mathrm{E}-3\end{array}$ & \\
\hline \multirow[t]{3}{*}{ Ambrosia Lake } & \#1 & 10 & $5.3 \mathrm{E}-2$ & $\operatorname{Ref} 20$ \\
\hline & $\# 1$ & 20 & $6.4 \mathrm{E}-3$ & \\
\hline & $\begin{array}{l}\# 2 \\
\# 2\end{array}$ & $\begin{array}{l}2 \\
6\end{array}$ & $\begin{array}{l}3.5 \mathrm{E}-2 \\
2.0 \mathrm{E}-2\end{array}$ & \\
\hline \multirow[t]{2}{*}{ Wyoming General } & \#1 & 11 & 8. $3 \mathrm{E}-3$ & $\operatorname{Ref} 20$ \\
\hline & \#2 & 1 & $8.8 \mathrm{E}-3$ & \\
\hline \multicolumn{3}{|c|}{ Concrete ( $5 \%$ porosity) } & $3.4 \mathrm{E}-4$ & $\operatorname{Ref} 12$ \\
\hline \multicolumn{3}{|c|}{ Concrete (18\% porosity) } & $2.0 \mathrm{E}-4$ & Ref 9 \\
\hline \multicolumn{3}{|c|}{ Concrete ( $1 \%$ porosity) } & $1.0 \mathrm{E}-2$ & Ref \\
\hline
\end{tabular}


used to obtain the correlation, ${ }^{(20)}$ are shown in Figure 3.1. The same data, plus other data points, used to obtain the correlation given by Eq 1-2, are presented in Figure 3.2. The latter correlation has a form similar to other correlations of gaseous diffusion in porous materials. The moisture content of soil covers is usually more readily available than the information required to estimate the air porosity of the material, so that the former correlation will be used in the examples given later in this chapter.

As stated previously, it is desired that values of $D_{e} / p$ be measured experimentally for a given material at its ambient moisture level and expected degree of compaction. Alternatively, $\mathrm{D}_{\mathrm{e}} / \mathrm{p}$ can be estimated solely from the moisture content and porosity of the material, because the large variation (four orders of magnitude) in $\mathrm{D}_{\mathrm{e}} / \mathrm{p}$ with moisture content obscures the much smaller effects on the value of $D_{e} / p$ from other soil properties. Hence, one of the more important characteristics of cover soils is their ability to retain moisture.

Although soils contain widely varying proportions of the three particle size categories, sand $(50-2,000 \mu \mathrm{m})$, silt $(2-50 \mu \mathrm{m})$, and clay $(<2 \mu \mathrm{m})$, they are generally referred to in terms of the predominant particle size fraction, i.e., clay soils contain greater than $40 \%$ clay-sized particles. Because the small clay particles contain various proportions of clay minerals, there is a great diversity of clays in nature; however, thay all generally have pronounced absorption and adsorption of moisture. Because clays, particularly montmorillonite, can retain significant amounts of moisture for extended periods of time, they are effective in attenuating radon; however, they must be protected from the surface effects of cracking and erosion. As an example of the water retention properties of clay, laboratory measurements of individual heavy clay types have measured hygroscopic water concentrations of 15 to $20 \%$. The hygroscopic water is held as a very thin $f i l m$ and requires the application of greater than 


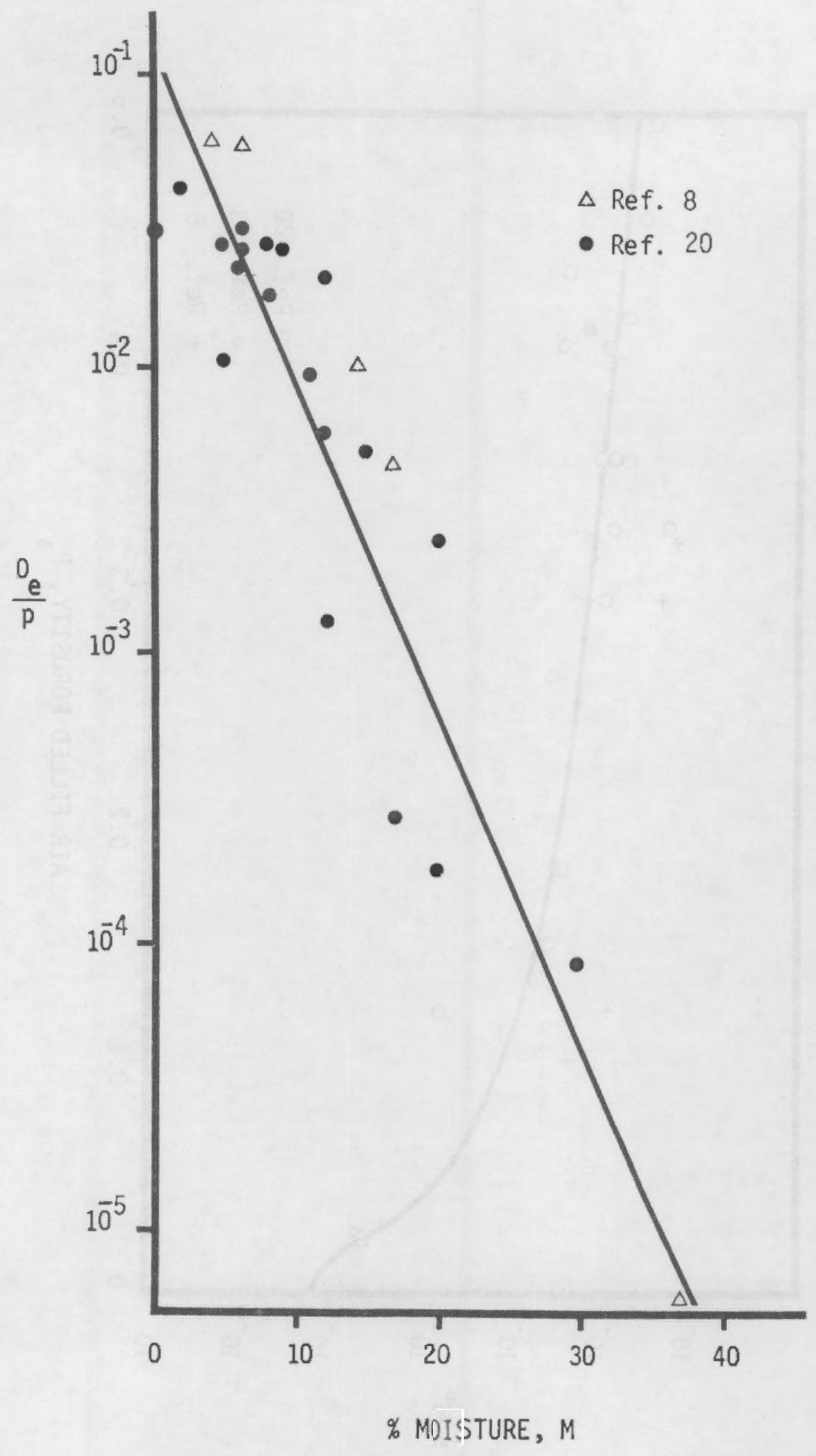

FIGURE 3.1 MOISTURE DEPENDENCE OF THE DIFFUSION COEFFICIENT 


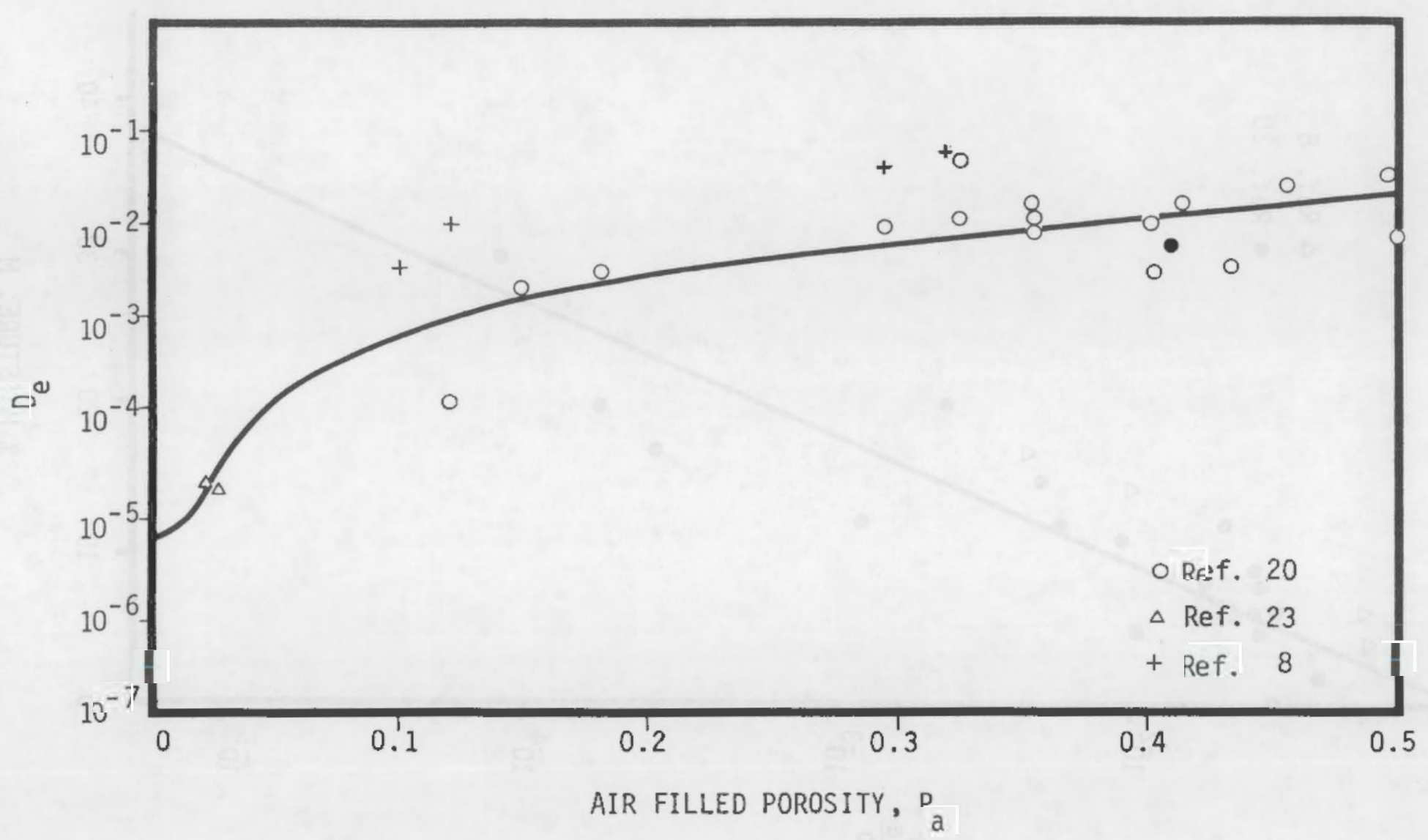

FIGURE 3.2 DIFFUSION COEFFICIENT AS A FUNCTION OF AIR FILLED POROSITY 
30 to 10,000 bars pressure to remove it. ${ }^{(39)}$

A survey of available drilling log information from ten sites in the uranium milling regions in Wyoming, Colorado, New Mexico and Utah yielded ambient moisture concentrations of near-surface clay soils ranging from 9 to $12 \%$, although a few isolated, undisturbed values exceeded $12 \%$. For non-clay soils the survey indicated moisture concentrations ranging from 6 to $10 \%$.

As part of the technology projects for the Inactive Uranium Mill Tailings Remedial Action Program, the above data have recently been correlated with soil-type, annual precipitation and annual evaporation. ${ }^{(40)}$ The following simple, preliminary correlation is useful in estimating average ambient soil moistures at depths of about ten feet:

$$
M=3.2 P_{r}^{\frac{1}{2}}-0.03 E_{v}+S \text {, }
$$

where

$$
\begin{aligned}
M & =\text { soil moisture (wt\%) } \\
P_{r} & =\text { annual precipitation (in) } \\
E_{v} & =\text { annual lake evaporation (in) } \\
S & =\text { soil index } \\
& =2.9 \text { for clay soils } \\
& =-1.0 \text { for sandy soils }
\end{aligned}
$$

Research on the moisture dependence of the diffusion coefficient is currently being conducted at Battelle Pacific Northwest Labortories and at RAE Corporation for both the Department of Energy and the Nuclear Regulatory Commission. 


\section{3 SURFACE FLUX AND COVER THICKNESS DETERMINATION}

After values for the diffusion coefficients and porosities of the tailings and cover materials are determined, the radon flux from the bare tailings is calculated using Eq 2-9; and the surface flux from the covered tailings is calculated with Eq 2-15. Figure 3.3 contains the results of cover calculations for a bare tailings flux of $J_{0}=280 \mathrm{pCi} / \mathrm{m}^{2} \mathrm{~s}$. Various soil moistures are used to obtain the curves in the figure. The cover moisture is the dominant parameter affecting the radon attenuation. When the flux attenuation is specified and the cover thickness must be determined, Eq 2-44 or 2-45 is used. Because the bare tailings flux can be expressed explicitly as a function of ore grade using $E q$ 3-1, and the parameters $E$ and $M_{0}$, the resulting form for $E q$ 2-45 with

$$
\begin{aligned}
& p_{0}=p_{1}, p_{b}=1.6 \mathrm{~g} / \mathrm{cm}^{3}, J_{1}=2 \mathrm{pCi} / \mathrm{m}^{2} \mathrm{~s} \text {, and } E=0.2 \text {, is: } \\
& x_{1}=2.28 \exp \left(-0.13 M_{1}\right)\left[\ln \left[4,200 \mathrm{G} \exp \left(-0.13 M_{0}\right)\right]\right. \\
& -\ln \left[1+\exp \left(0.13\left(M_{1}-M_{0}\right)\right)+\frac{1-\exp \left(0.13\left(M_{1}-M_{0}\right)\right)}{\left[(2,100 \mathrm{G}) \exp \left(-0.13 M_{0}\right)\right]^{2}}\right]
\end{aligned}
$$

Results of this expression are tabulated in Tables B.1 - B.11 in Appendix $B$ for $G$ from $0.05-0.30, M_{0}$ from 3 to $15 \%$, and $M_{1}$ from 5 to $15 \%$. The ranges of these parameters are compatible for ambient soils of the western United States milling and mining regions. The $D_{e} / p$ values are also given in the tables so that they may be useful even if the moisture correlation of Eq 1-1 is modified, or other moisture correlations are used for $D_{e} / p$. Once the correct $D_{e} / p$ has been determined for the tailings and cover soil, then the tables give the correct thicknesses.

The sensitivity of the cover thickness to variations in ore grade, tailings 


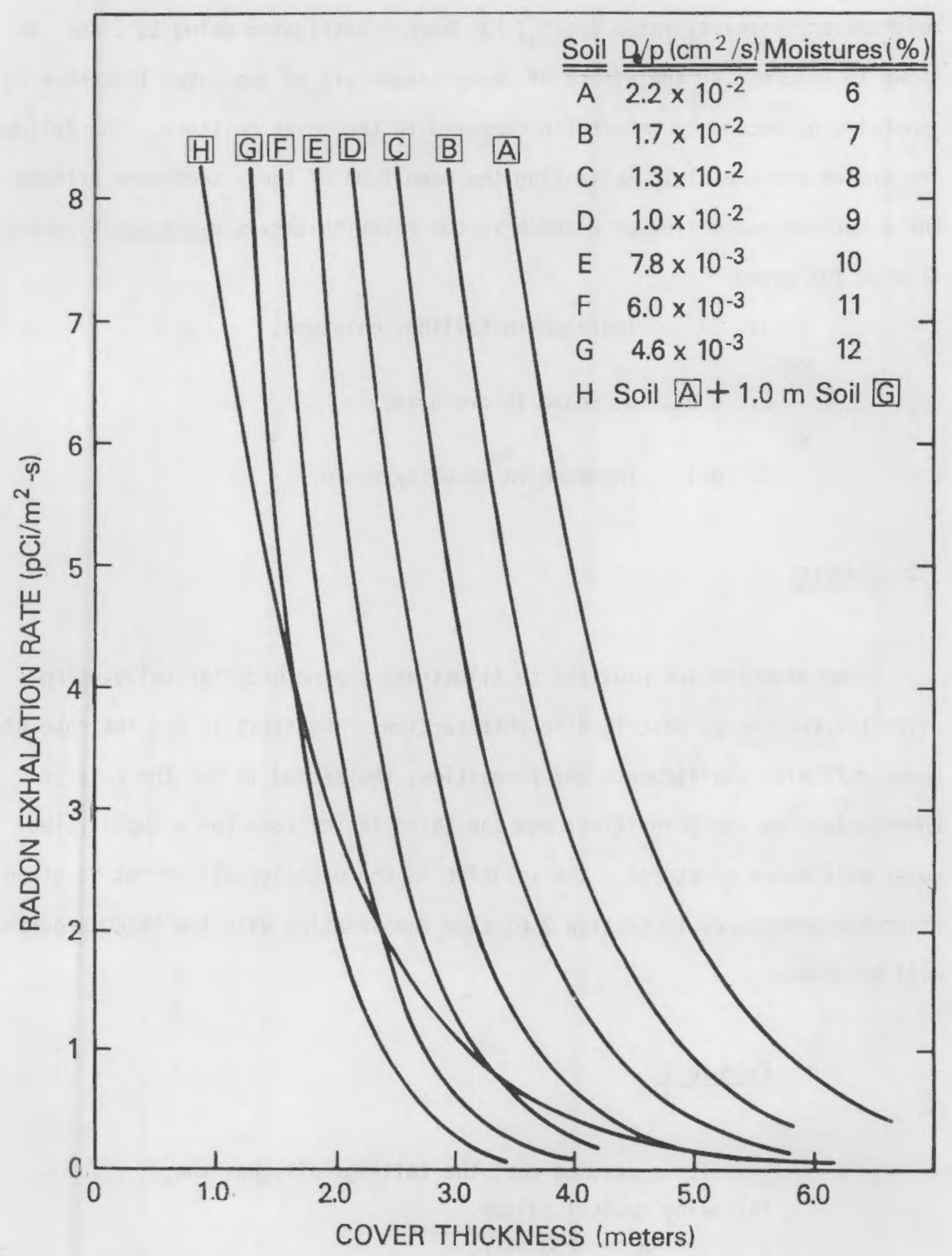

FIGURE 3.3 EFFECT OF SOIL THICKNESS ON RADON EXHALATION RATE 
moisture and porosity ratio $\left(p_{0} / p_{1}\right)$ has been investigated using Eq 2-45. As shown in Figure 3.4, the effect of these parameters on the cover thickness is generally of secondary importance compared to the cover moisture. The following trends are useful in estimating the magnitude of these secondary effects. For a surface radon flux of $2 \mathrm{pCi} / \mathrm{m}^{2} \mathrm{~s}$, the cover thickness decreases by about five $\mathrm{cm}$ for every

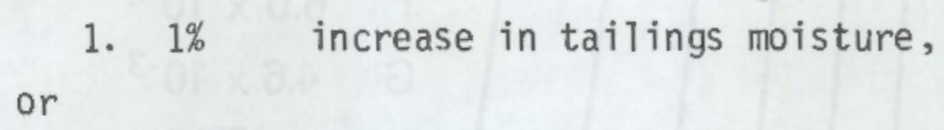

1. $1 \%$ increase in tailings moisture,

or

2. $0.01 \%$ decrease in ore grade, or

3. 0.1 increase in porosity ratio.

\subsection{EXAMPLES}

Three examples are provided to illustrate the methods for calculating cover thicknesses as described in this section. The first is for the case of known diffusion coefficients and porosities; the second is for the case of known moistures and porosities; and the third is the case for a two-layered cover with known moistures. The solution to the examples will first be given using the procedures in Section 2.6, then the solution with the RAECO program will be given.

\section{Example 1}

It is assumed that the tailings pile has the following typical values:

$$
\begin{aligned}
R & =280 \mathrm{pCi} / \mathrm{g} \\
\rho_{b} & =1.6 \mathrm{~g} / \mathrm{cm}^{3} \\
E & =0.2
\end{aligned}
$$




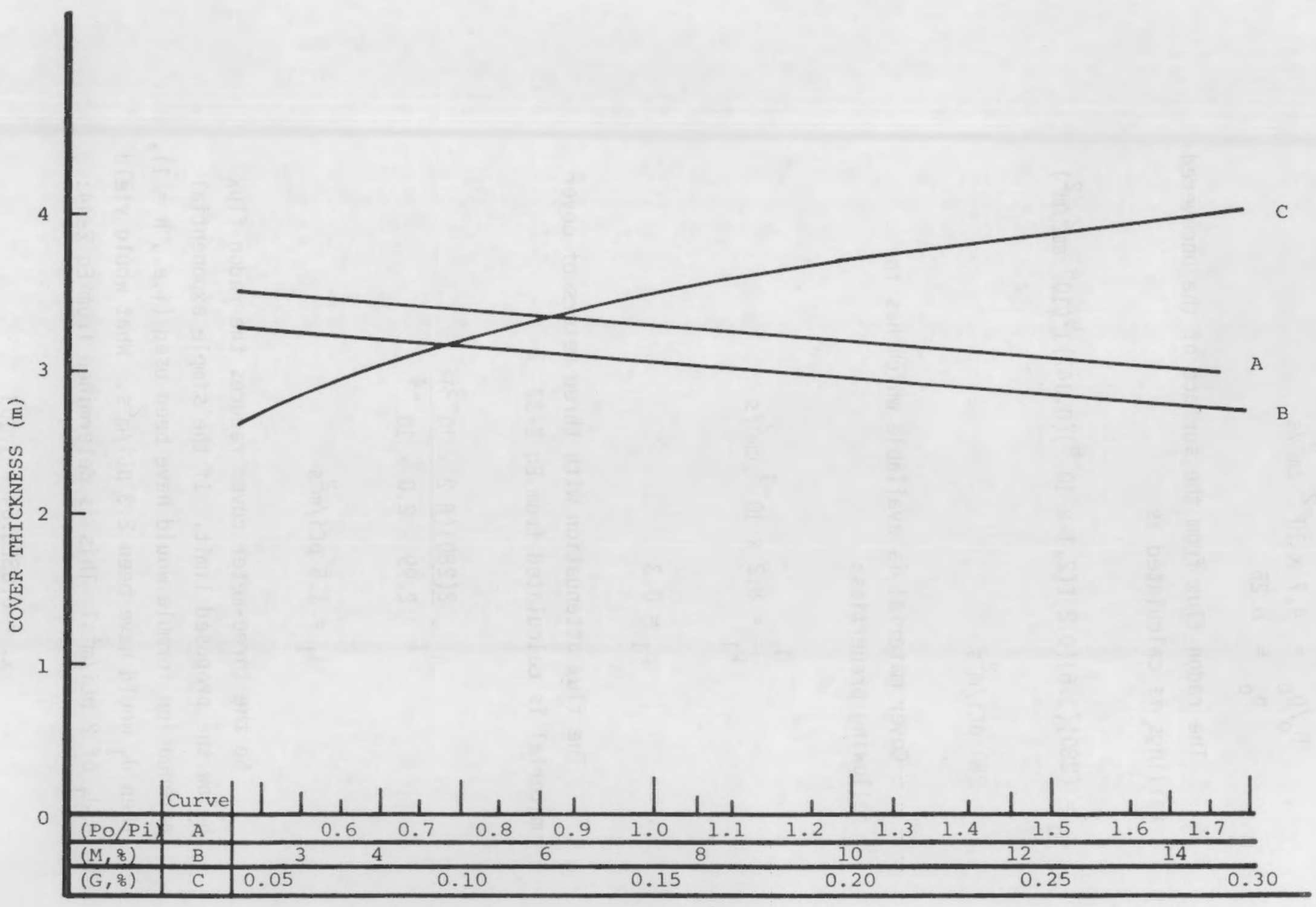

FIGURE 3.4 TAILINGS COVER THICKNESS VARIATION WITH POROSITY RATIO, TAILINGS MOISTURE AND ORE GRADE 


$$
\begin{aligned}
D_{0} / P_{0} & =4.7 \times 10^{-2} \mathrm{~cm}^{2} / \mathrm{s} \\
P_{0} & =0.25
\end{aligned}
$$

The radon flux from the surface of the uncovered tailings is calculated as

$$
\begin{aligned}
J_{0} & =(280)(1.6)(0.2)\left[\left(2.1 \times 10^{-6}\right)(0.047)\right]^{\frac{1}{2}}\left(10^{4} \mathrm{~cm}^{2} / \mathrm{m}^{2}\right) \\
& =280 \mathrm{pCi} / \mathrm{m}^{2} \mathrm{~s}
\end{aligned}
$$

Cover material is available which has the following properties:

$$
\begin{aligned}
& \frac{p_{1}}{p_{1}}=8.2 \times 10^{-3} \mathrm{~cm}^{2} / \mathrm{s} \\
& p_{1}=0.3
\end{aligned}
$$

The flux attenuation with three meters of cover material is calculated from Eq 2-37

$$
\begin{aligned}
& J_{1}=\frac{2(280)\left(8.2 \times 10^{-3}\right)}{2.99-2.0 \times 10^{-4}} \\
& J_{1}=1.5 \mathrm{pCi} / \mathrm{m}^{2} \mathrm{~s}
\end{aligned}
$$

So the three-meter cover reduces the radon flux below the proposed limit. If the simple exponential attenuation formula would have been used (i.e., $h=1$ ), then $\mathrm{J}_{1}$ would have been $2.3 \mathrm{pCi} / \mathrm{m}^{2} \mathrm{~s}$. What would yield a $\mathrm{J}_{1}$ of $2 \mathrm{pCi} / \mathrm{m}^{2} \mathrm{~s}$ ? This is determined from Eq 2-44:

$$
\begin{aligned}
& x_{1}=0.63[5.64-1.10] \\
& x_{1}=2.8 \mathrm{~m}
\end{aligned}
$$


What thickness of $10 \%$ moisture cover soil will attenuate the radon flux from an $8 \%$ moisture tailings pile to a value of $2 \mathrm{pCi} / \mathrm{m}^{2} \mathrm{~s}$ ? The porosities are the same, and all other tailings parameters are given previously.

The answer can be obtained using Eq 2-46 once $J_{0}$ is determined.

$\frac{D_{0}}{P_{0}}=0.106 \exp (-0.261(8))$

$\frac{D_{0}}{P_{0}}=0.013 \mathrm{~cm}^{2} / \mathrm{sec}$

$J_{0}=(280)(1.6)(0.2)\left[\left(2.1 \times 10^{-6}\right)(0.013)\right]^{\frac{1}{2}} \times 10^{4}$

$\mathrm{J}_{0}=149 \mathrm{pCi} / \mathrm{m}^{2} \mathrm{~s}$, and

$x_{1}=(0.62)(5.00-0.832)$

$x_{1}=2.6 \mathrm{~m}$

Example 3

The tailings pile described in Example 2 is to be covered with one meter of a good quality clay capable of retaining $12 \%$ moisture and sufficient overburden at $6 \%$ moisture to achieve a surface flux of $2 \mathrm{pCi} / \mathrm{m}^{2} \mathrm{~s}$. What thickness of overburden should be used? Assume equal porosities for all materials. 
First, determine the diffusion coefficients:

$$
\begin{array}{ll}
\text { tailings } & \frac{D_{0}}{p_{0}}=0.013 \mathrm{~cm}^{2} / \mathrm{s} \\
\text { clay } & \frac{D_{1}}{p_{1}}=0.0046 \mathrm{~cm}^{2} / \mathrm{s} \\
\text { overburden } & \frac{D_{2}}{p_{2}}=0.022 \mathrm{~cm}^{2} / \mathrm{s}
\end{array}
$$

Then, calculate the attenuation through the clay component using Eqs 2-38 and 2-39.

$$
\begin{aligned}
& J_{1}=(149)\left[\frac{2}{2.682-(0.682)(0.014)}\right](0.119) \\
& J_{1}=13 \mathrm{pCi} / \mathrm{m}^{2} \mathrm{~s} .
\end{aligned}
$$

Now, determine the diffusion coefficient for the source term to the overburden (the source is now the taijings and ciayj using $\bar{E} y \mathbf{z}-5 j$.

$$
\begin{aligned}
& \frac{\mathrm{DS}}{\overrightarrow{\mathrm{ps}}}{ }_{2}=\frac{\mathrm{D}_{0}}{\mathrm{P}_{0}} \exp \left(-\mathrm{a}_{1} \mathrm{x}_{1}\right)+\frac{\mathrm{D}_{1}}{\mathrm{p}_{1}}\left[1-\exp \left(-\mathrm{a}_{1} \mathrm{x}_{1}\right)\right] \\
& \frac{\mathrm{DS}}{\mathrm{PS}_{2}}=(0.013)(0.088)+(0.0046)(1-0.088) \\
& \frac{\mathrm{DS_{2 }}}{\mathrm{ps}_{2}}=0.0053 \mathrm{~cm}^{2} / \mathrm{s}
\end{aligned}
$$

This expression is substituted for $D_{0} / P_{0}$, and $J_{1}=$ 13 is substituted for $J_{0}$ in Eq 2-44. 


$$
\begin{aligned}
& x_{2}=(1.02)[2.56-\ln [1.491 \cdots(1-0.491)(0.024)]] \\
& x_{2}=2.3 \mathrm{~m}=\text { overburden thickness }
\end{aligned}
$$

So the total cover thickness is $3.2 \mathrm{~m}$.

\subsection{EXAMPLE CALCULATIONS WITH RAECO}

The parameters specified in Section 3.4 were used to construct the input to the RAECO program as specified in Appendix A. Table 3.2 contains the input data set for the three examples.

The calculation for Example 1, shown in Table 3.3, specifies a cover thick-

ness of $2.8 \mathrm{~m}$ in order to achieve surface flux of $2 \mathrm{pCi} / \mathrm{m}^{2} \mathrm{~s}$ from the tailings.

The results of the Example 2 calculations are shown in Table 3.4. A cover thickness of $2.6 \mathrm{~m}$ is sufficient to give a surface radon flux of $2 \mathrm{pCi} / \mathrm{m}^{2} \mathrm{~s}$ from the tailings.

The multilayer cover example calculations, shown in Table 3.5 , yield an overburden thickness of $2.35 \mathrm{~m}$, which is just slightly greater than the $2.3 \mathrm{~m}$ thickness calculated by the procedure given in Section 2.6 , but still well within acceptable uncertainty limits.

\subsection{COVER SOURCE CONSIDERATIONS}

The example calculations of the previous section did not consider any surface radon flux contribution from radium in the covers. The cover source term was set equal to zero. For soil cover materials containing background values of radium, the effect of the radon from the covers is very small and 
TABLE 3.2

INPUT DATA SET FOR RAECO CALCULATIONS
OF EXAMPLE PROBLEMS

URAHIUH MILL TAILIHGS GEIS, APPEHIXX F -EX. I $2,0 ., 00,0,0 ., 0.001$

$500 ., 0.01175,0.25,1.882 \mathrm{E}-3$

$283.574,0.00246,0.3,0$.

URANIUN HILL TAILINGS GEIS, APPENUIX $P$-EX. 2

$2,0 ., 0,0,0 ., 0.001$

$500,0.00325,0.25,1.882 \mathrm{E}-4$

$260 ., 0002338,0.3,0$.

URANIUS HILL TAILINGS GEI5, APFENUIX P -EX.3

$3,0 ., 0 ., 0,0 ., 001$

$500,0.00325,0.25,1.98 .2 E-4$

$100 ., 0.00138,0.3,0$.

$235 ., 0.0066,0.3,0$. 
TABLE 3.3

RAECO CALCULATION OF EXAMPLE 1

:*:*:k UR'ANIUH KILL TAILINGS GEIS, AFFEHIIX P -EX. 1

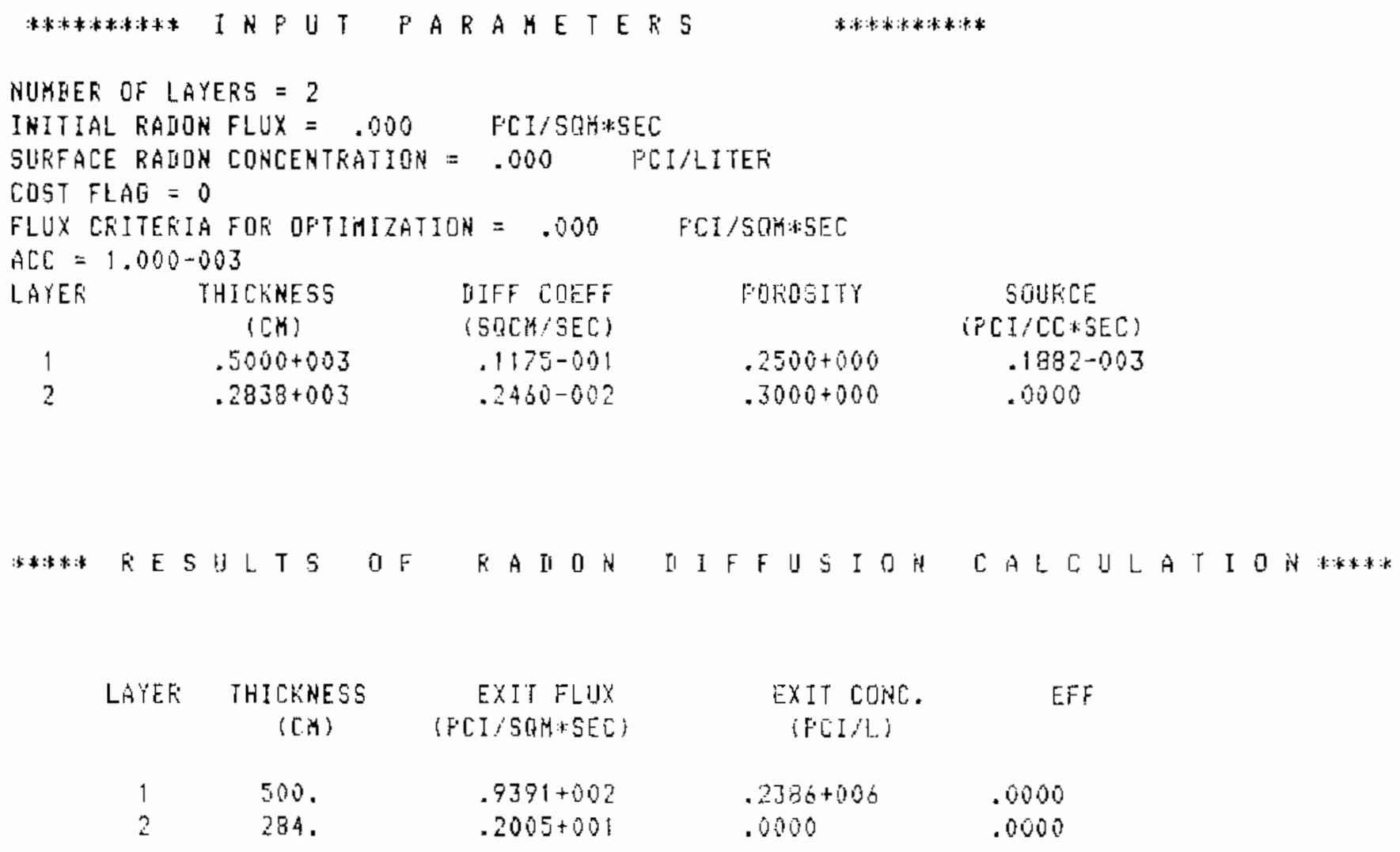


TABLE 3.4

RAECO CALCULATION OF EXAMPLE 2

:***:* URANIUH MILL TAILIHGS GEIS, APPENDIX P -EX, 2

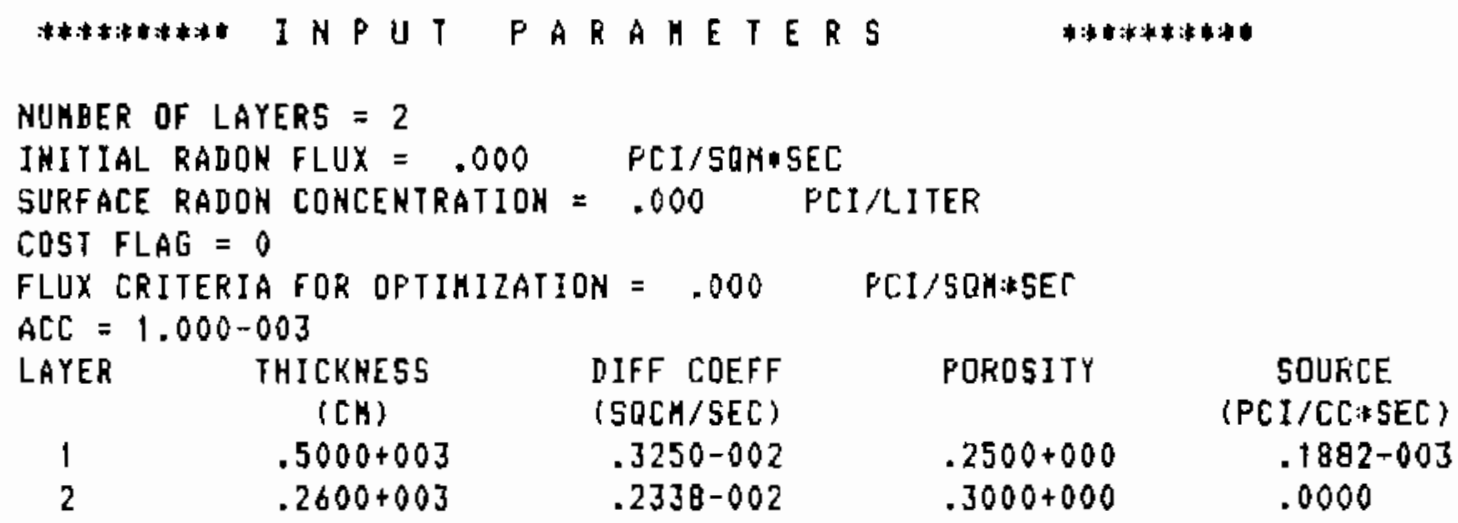

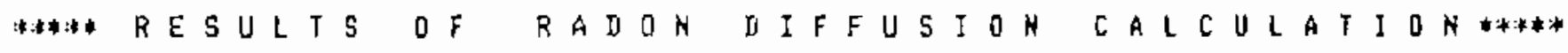

$\begin{array}{ccccc}\text { LAYER } & \text { THICXNESS } & \text { EXIT FLUX } & \text { EXIT CONC. } & \text { EFF } \\ & (\text { CA }) & (P C I / S Q M \text { SEC) } & (\text { PCI } / L) & \\ 1 & 500 . & .7120+002 & .1855+006 & .0000 \\ 2 & 260 . & .1996+001 & .0000 & .0000\end{array}$


TABLE 3.5

RAECO CALCULATION OF EXAMPLE 3

:*:*:* URANIUN MILL IAILINGS GEIS, APPENDIX P -EX.3

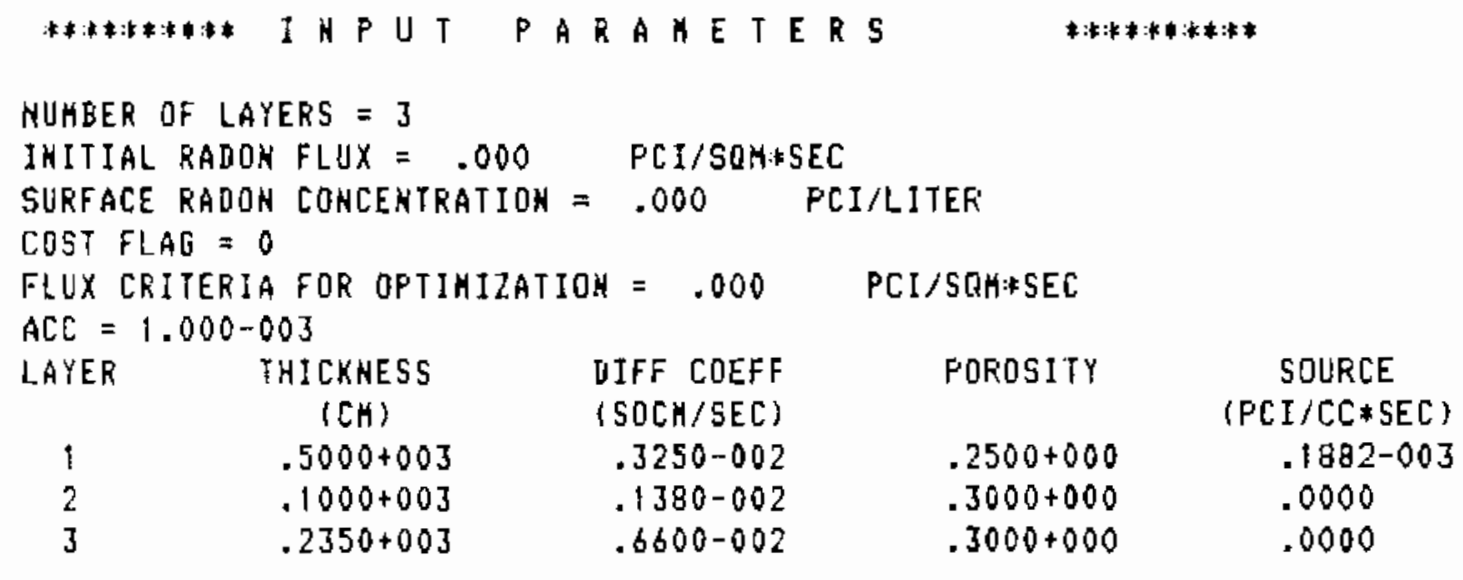

*:*:** RESULIS OF RADON DIFFUSIOH CALCULA T I O H *:**:*

$\begin{array}{ccccc}\text { LAYER } & \begin{array}{c}\text { THICKNESS } \\ (C H)\end{array} & \begin{array}{c}\text { EXIT FLUX } \\ \text { (PCI/SOH*SEC) }\end{array} & \begin{array}{c}\text { EXIT CONC. } \\ (\mathrm{FCI} / \mathrm{L})\end{array} & \text { EFF } \\ & & & & \\ 1 & 500 . & .6196+002 & .2080+006 & .0000 \\ 2 & 100 . & .1006+002 & .1529+005 & .0000 \\ 3 & 235 . & .2007+001 & .0000 & .0000\end{array}$


is approximately additive, so that the component of the radon flux from radium in the cover material does not appreciably alter the component of the radon flux from radium in the tailings. Furthermore, the linearity assumption for tailings plus cover fluxes is conservative, that is, the surface flux due only to the tailings is slightly less with a cover source term than without the cover source term. For example, the radon flux from radium in the cover specified in Example 2 is $0.82 \mathrm{pCi} / \mathrm{m}^{2} \mathrm{~s}$, as determined by a RAECO calculation. A RAECO calculation of the total surface radon flux from radium in both the tailings and the cover is $2.80 \mathrm{pCi} / \mathrm{m}^{2} \mathrm{~s}$. Subtracting the cover contribution of $0.82 \mathrm{pCi} / \mathrm{m}^{2} \mathrm{~s}$ from the total flux yields a value of $1.98 \mathrm{pCi} / \mathrm{m}^{2} \mathrm{~s}$ of the total surface flux that is attributed to the tailings. This is in excellent agreement with, but is slightly less than, the surface fiux of $2.00 \mathrm{pCi} / \mathrm{m}^{2} \mathrm{~s}$ previously calculated assuming no radium in the cover materials. 


\section{SUMMARY AND CONCLUSIOISS}

The radon releases from bare and covered tailings can be estimated using diffusion theory, if appropriate diffusion coefficients are used. The procedures for calculating the thickness of an adequate cover system are straightforward and the calculations can be performed by hand or by computer programs such as the RAECO code. A procedural checklist for the hand calculations is given in Table 4.1.

As shown in the table, first the values for all pertinent parameters must be determined, then an initial tailings-cover system configuration must be developed and finally the surface flux and cover thickness calculations are performed. Multilayer covers require a cyclical calculation starting with the lowest layer and proceeding to the top layer.

A site-specific example (41) of this procedure is now presented.

The values used for computing the bare tailings flux for the Hansen Project facility are as follows:

$$
\begin{aligned}
R & =231.8 \mathrm{pCi} / \mathrm{g} \\
\mathrm{p} & =1.6 \mathrm{~g} / \mathrm{cm}^{3} \\
E & =0.2 \\
D_{0} / P_{0} & =0.01314 \mathrm{~cm}^{2} / \mathrm{s}
\end{aligned}
$$

The value of $D_{0} / P_{0}=0.01314 \mathrm{~cm}^{2} / \mathrm{s}$ was obtained from Eq $4-1$ based on a tailings residual moisture of $8 \%$. Substitution of the above values into Eq 4-3 yieids 
TABLE 4.1

PROCEDURAL CHECKLIST FOR CALCULATING ADEQQUATE COVER THICKNESS

1. DETERMIIVE THL REQUIRED COVER THICKNESS

2. DeterHINe SOURCE tern PARAlieters, $R, E, \rho_{b}$, $P_{0} \cdot D_{0}$

3. DETERMINE COVER MATERIAL PARAMETERS, $0_{i}, p_{i}$

4. CALCULATE BARE TAILINGS FLUX aND COVER ATTENUATION PARAMETER

5. CALCULATE SURFACE FLUX OR COVER THICXNESS

If desired, the required cover thickness can be obtained from the tables in Appendix B given the

Defauit values, $R=2,800 \mathrm{G}, \mathrm{E}=0.2, P_{\mathrm{b}}=1.6$ $p_{0}=0.35$

Default value, $p_{i}=0.35$

$$
D_{0} / P_{0}=0.106 \exp \left\{-0.261 M_{0}\right\}
$$

$$
D_{i} / p_{i}=0.106 \exp \left\{-0.261 M_{1}\right\}
$$

$$
\begin{aligned}
& u_{0}=R_{a_{b}} E\left(\lambda D_{0} / p_{0}\right)^{2} \\
& b_{1}=\left(\lambda p_{1} / D_{1}\right)^{2}
\end{aligned}
$$

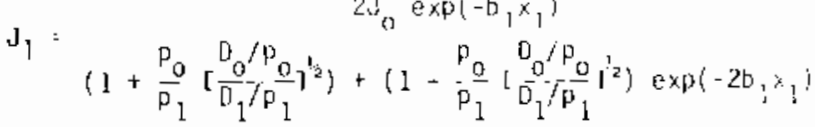

$$
\begin{aligned}
& x_{1}=b_{1}\left(\ln \left(\frac{2 J_{0}}{J_{1}}\right)-\ln \left(\left(1+\frac{p_{0}}{p_{1}} \frac{o_{0} / p_{0}}{D_{1}} p_{1} p_{1}^{\frac{1}{2 / 2}}\right)\right.\right.
\end{aligned}
$$

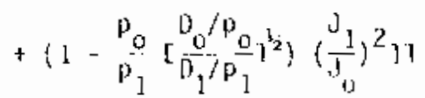

$$
\begin{aligned}
& a_{i}=b_{i} / \sqrt{h_{i}} \\
& \frac{D_{S n l}}{p_{S m}}=\sum_{i=0}^{m-1} \frac{a_{i}}{p_{i}}\left[1-\exp \left(-a_{i} x_{i}\right)\right] \exp \left(-\sum_{j=i+1}^{m-1} a_{i} x_{i}\right)
\end{aligned}
$$

If multiple layers are in the cover, calculate item 5 for the first cover layer, then calculate ltem 6 for the second cover layer, then calculate Item 5 for the second cover layer, and so on until Item 5 is calculated for the top layer. 


$$
\begin{aligned}
J_{0}= & (231.8 \mathrm{pCi} / \mathrm{g})\left(1.6 \mathrm{~g} / \mathrm{cm}^{3}\right)(0.2) \times\left(2.1 \times 10^{-6} \mathrm{~s}^{-1} \times 0.01314 \mathrm{~cm}^{2} / \mathrm{s}\right)^{\frac{1}{2}} \\
& \times 10^{4} \mathrm{~cm}^{2} / \mathrm{m}^{2}=123.2 \mathrm{pCi} / \mathrm{m}^{2} \mathrm{~s}
\end{aligned}
$$

Equation 4-3 assumes effectively infinite depth of tailings. A factor given by tanh $\left[x_{0} \sqrt{\lambda p_{0} / D_{0}}\right]$, where $x_{0}$ the depth of tailings, is used to account for finite depth of tailings. However, in cases where the average depth of tailings is three meters or more, the factor is effectively unity.

The cover system consists of three feet of compacted clay, 6.5 feet of random fill or overburden, and one-half foot of topsoil. The long-term moisture content of the clay is estimated to be $12.3 \%$ and the topsoil and the overburden wi 11 maintain a moisture concentration of $10.5 \%$. Equation $4-5$ is used to estimate the radon flux from the surface of the clay cover.

The following $D / p$ values are computed from Eq 4-2:

$$
\begin{aligned}
& D_{0} / P_{0}=0.01314 \mathrm{~cm}^{2} / \mathrm{s} \text { (tailings, } 8 \% \text { moisture) } \\
& D_{1} / p_{1}=0.0043 \mathrm{~cm}^{2} / \mathrm{s} \text { (clay layer, } 12.3 \% \text { moisture), }
\end{aligned}
$$

Using the above values, the previously calculated radon flux, and assuming the porosities are equal for ali materials yields $J_{1}=12 \mathrm{pCi} / \mathrm{m}^{2} \mathrm{~s}$ from Eq 4-5. Equation 4-5 can aiso be written as

$$
\mathrm{J}_{1}=\mathrm{J}_{0} f \exp \left(-\mathrm{b}_{1} \mathrm{x}_{1}\right)
$$


where

$$
f=\frac{2}{\left(1+\frac{p_{0}}{p_{1}}\left[\frac{D_{0} / p_{0}}{D_{1} / p_{1}^{\frac{1}{2}}}\right)+\left(1-\frac{p_{0}}{p_{1}}\left[\frac{D_{0} / p_{0}}{D_{1} p_{1}}\right]^{\frac{1}{2}}\right) \exp \left(-2 b_{1} x_{1}\right)\right.}
$$

The function $f$ is useful in calculating the composite diffusion coefficient. This composite diffusion coefficient is computed by Eq 4-7. Thus, the composite $D / p$ is computed as:

$$
\frac{D_{s 2}}{P_{52}}=D_{0} / P_{0}\left[-\exp \left(-a_{i} x_{i}\right)\right]+D_{j} / P_{i}\left[1-\exp \left(-a_{i} x_{i}\right)\right]
$$

where

$$
\begin{aligned}
D_{0} / P_{0} & =0.01314 \mathrm{~cm}^{2} / \mathrm{s} \\
D_{1} / p_{1} & =0.0043 \mathrm{~cm}^{2} / \mathrm{s} \\
x_{1} & =91.44 \mathrm{~cm} \\
a_{1} & =\left[2.1 \times 10^{-6} \mathrm{~s}^{-1} / 0.0043 \mathrm{~cm}^{2} / \mathrm{s} \times \mathrm{h}\right]
\end{aligned}
$$

Now

$$
\begin{aligned}
h & =\left[1-\frac{1}{b_{1} x_{1}} \ln f\right]^{-2} \\
& =\left[1-\frac{1}{(0.0221) \times 91.44} \ln (0.7313)\right]^{-2} \\
& =0.75
\end{aligned}
$$

and 


$$
\begin{aligned}
a_{1} & =\left(\frac{2.1 \times 10^{-6} \mathrm{~s}^{-1}}{0.043 \mathrm{~cm}^{2} / \mathrm{s} \times 0.75}\right)^{\frac{1}{2}} \\
& =0.0255
\end{aligned}
$$

Equation 4-7 now becomes:

$$
\frac{D_{s 2}}{p_{s 2}}=0.01314(0.0971)+0.0043(1-0.0971)=0.0052 \mathrm{~cm}^{2} / \mathrm{s}
$$

Equation 4-6 yields the minimum required depth of overburden-topsoil in addition to the clay layer by using the following quantities:

$$
\begin{aligned}
D_{0} / P_{0} & =0.0052 \mathrm{~cm}^{2} / \mathrm{s} \\
p_{0} / p_{1} & =1 \\
J_{1} & =2 \mathrm{pCi} / \mathrm{m}^{2} \mathrm{~s} \\
J_{0} & =12 \mathrm{pCi} / \mathrm{m}^{2} \mathrm{~s} \\
D_{1} / p_{1} & +0.106 \exp (-0.106 \times 10.5 \%)=0.0068 \mathrm{~cm}^{2} / \mathrm{s}
\end{aligned}
$$

The moisture content of the overburden-topsoil is $10.5 \%$, as mentioned previousiy. A value of $x_{1}=105.3 \mathrm{~cm}$ or $x_{1}=1.05 \mathrm{~m}$ of overburden-topsoil is abtained. Thus, the total cover needed to achieve the minimum radon flux of $2 \mathrm{pCi} / \mathrm{m}^{2} \mathrm{~s}$ is

$0.92 \mathrm{~m} \mathrm{clay}$

$+1.05 \mathrm{~m}$ overburden-topsoil

$1.96 \mathrm{~m}$ total cover 
It is also of interest to calculate the surface radon flux if seven feet of overburden-topsoil is placed over the three feet of clay.

Using Eq 4-5 with the values

$$
\begin{aligned}
& J_{0}=123.22 \mathrm{pCi} / \mathrm{m}^{2} \mathrm{~s} \\
& \left.b_{1}=\frac{2.1 \times 10^{-6} \mathrm{~s}^{-1 \frac{1}{2}}}{0.0068 \mathrm{~cm}^{2} / \mathrm{s}}\right]^{-10} \\
& D_{0} / P_{0}=0.01314 \mathrm{~cm}^{2} / \mathrm{s} \text { (the diffusion coefficient of the tailings) } \\
& D_{1} / p_{1}=0.0068 \mathrm{~cm}^{2} / \mathrm{s} \text { (the diffusion coefficient of the sand-soil) } \\
& x_{1}=304.8 \mathrm{~cm} \text { (i.e., } 10 \mathrm{ft} \text {, the depth of cover), }
\end{aligned}
$$

then

$$
J_{1}=0.5 \mathrm{pCi} / \mathrm{m}^{2} \mathrm{~s}
$$

The above calculations are performed by hand. If a suitable computer program is used such as RAECO, items $1-3$ of Table 4.1 provide sufficient information to prepare a complete data set in the format given in Appendix A. 


\section{REFERENCES}

1. Final Generic Environmental Impact Statement on Uranium Millings, U.S. NRC Report NUREG-0706, September 1980.

2. G.E. Harrison, "The Diffusion of Radon Gas Mixtures," University of Birmingham, 1938.

3. E.M. Kovach, "Meteorological Influences Upon the Radon-Content of Soi1Gas," Transaction, American Geophysical Union, 26, No. II, 1945.

4. B.J. Giletti and J.L. Kulp, "Radon Leakage from Radioactive Minerals," Columbia University, 1954.

5. S.L. Jaki and V.F. Hess, "A Study of the Distribution of Radon, Thoron, and Their Decay Products Above and Below the Ground," Fordham University, 1958.

6. H.B. Evans, "Factors Influencing Permeability and Diffusion of Radon in Synthetic Sandstones, "University of Utah, 1959.

7. H.W. Kraner, G.L. Schroeder, and R.D. Evans, "Measurements of the Effects of Atmosheric Variables on Radon 222 Flux and Soil-Gas Concentration," The Natural Radiation Environment, J.A.S. Adams and W.M. Lowder, Eds., University of Chicago Press, 1964.

8. Allen B. Tanner, "Radon Migration in the Ground: A Review," The Natural Radiation Environment, J.A.S. Adams and W.M. Lowder, Eds., University of Chicago press, 1964.

9. H.W. Kraner, G.L. Schroeder, and R.D. Evans, "Annual Progress Report to AEC," MIT-952-4, 1967.

10. Wilkening, M.H. and J.E. Hand, "Radon Flux at the Earth-Air Interface," J. Geophys. Res. 65, 3367-3370, 1960.

11. Wilkening, M.H., W.E. Clements and D. Stanley, "Radon-222 Flux Measurements in Widely Separated Regions," The Natural Radioation Environment II, J.A.S. Adams and W.M. Lowder, Eds., The University of Chicago Press, 1975.

12. M.V.J. Culot, H.G. 01son, and K.J. Schiager, "Effective Diffusion Coefficient of Radon in Concrete Theory and Method for Field Measurements," Health Physics, 30, p. 263, March 1976.

13. K.J. Schiager, "Analys is of Radiation Exposures on or Near Uranium Mil1 Tailings Piles," Radiation Lata and Reports, No. 7, July 1974.

14. M.Y.J. CuTot, H.G. 01son, and K.J. Schiager, "Radon Progeny Control in Buildings," Colorado State University, Fort Collins, Colorado, May 1973. 
15. J.C. Franklin, et.al., "Effects of Moisture on Radon Emanation," U.S. Bureau of Mines Technical Progress Report 1978.

16. R.C. Bates and J.E. Edwards, "Radon Emanation Relative to Changing Barometric Pressure and Physical Constraints," Second Conference on Uranium Mining Technology, Reno, Nevada, Noventer 1978.

17. A.B. Tanner, "Radon Migration in the Ground--A Supplementary Review," The Natura] Radiation Envi ronment II, J.A.S. Adams and W.M. Lowder, Eds., The University of Chicago Press, 1975.

18. K.K. Nielson, B.J. Thamer, K.M. Putzig, "The Effects of Moisture on Radon Emanation and Diffusion," Bureau of Mines Report, FBDU-315-1, January 1980.

19. P.J. Macbeth, et al., "Laboratory Research on Tailings Stabilization Methods and Their Effectiveness in Radiation Containment," Department of Energy Report GJT-21, April 1978.

20. V.C. Rogers, et al., "Characterization of Uranium Tailings Cover Materials for Radon Flux Reduction," NUREG/CR-1081, March 1980.

21. M.H. Momeni, et a1., "Radiological Impact of Uranium Tailings and Alternatives for Their Management, "Proceedings of the Health Physics Society 12th Mid-Year Topical Symposium, "Low-Leve] Radioactive Waste Management," U.S. EPA 520/3-79-002, February 1979.

22. H.B. Silker and P.G. Heasler, "Diffusion and Exhalation of Radon from Uranium Tailings," Battelle Pacific Northwest Laboratory, NUREG/CR-1138, PNL-3207, October 1979.

23. R.W. Nelson, G.W. Gee, and C.A. Oster, "Radon Control by Multilayer Earth Barriers," Symposium of Uranium Mill Tailings Management, Ft. Collins, Colorado, November 1980.

24. E. Buckingham, "Contributions to Our Knowledge of the Aeration of Soils," U.S. Department of Agr. Bur. Soils Bulletin, No. 25, 1904.

25. K.K. Nielson, et aT., "Laboratory Measurements of Radon Diffusion Through Aultilayered Cover Systems for Uranium Tailings,: (In Preparation).

26. B.J. Thamer, et al., "Radon Diffusion and Cover Material Effectiveness for Uranium Tailings Stabilization," Ford, Bacon and Davis Report, FBDU-258, May 1980.

27. V.C. Rogers, et al., "A New Laboratory Technique for Measuring Diffusion Coefficients of Mil1 Tailings Covers," Trans. Am. Nuc. Soc., 34, 132, 1980.

28. R. Bates, "Time Dependent Rn-222 Loss from Small Samples," Hea?th Physics 38,1980 .

29. B.L. Cohen, "Laboratory Measurements of Diffusion Constants for Mil1 Tailings Covers and Its Application," Trans. Amer. Nuc. Soc. 33, p. 173, 1979. 
30. Reference deleted - see footnote on page 6 .

31. P.L. Koehmstedt, J.N. Hartley, and D.K. Davis, "Use of Asphalt Emulsion Sealants to Contain Radon and Radium in Uranium Tajlings, "Pacific Northwest Laboratory Report, BNWL-2190, 1977.

32. J.N. Hartley, et al., "Application of Asphalt Emulsion to Uranium Mill Tailings," Symposium of Uranium Mi11 Tailings Management, Ft. Collins, Colorado, November 1980.

33. J.C. Franklin, et al., "Barriers for Radon in Uranium Mines," U.S. Bureau of Mines Report, RI-8259, 1977.

34. J. Pohl-Ruling, F. Stienhauser, and E. Pohl, "Investigation on the Suitability of Various Materials as Rn-222 Diffusion Barriers," Health Physics 39 , p. $299,1980$.

35. Y.C. Yuan and C.J. Roberts, "Numerical Investigation of Radon Transport Through a Porous Medium," Trans. of the American Nuc, Soc., 38, p. 108, 1981.

36. K.K. Nielson and V.C. Rogers, "Radon Flux Through Multi-Layered Covers Over Uranium Mill Tailings," Trans. Amer. Nuc. Soc., 34, p. 131, 1980.

37. V.C. Rogers, G.M. Sandquist, and K.K. Nielson, "Radon Attenuation Effectiveness and Cost Uptimization for Uranium Mill Tailings and Composite Covers," U.S. DOE Report, UMTRA-DOE/ACO 165, JuTy 1981.

38. K.K. Nielson, et al., "Effects of Moisture on Radon Emanation and Diffusion," Ford, Bacon and Davis Report, FBDU-315-2 Report, July 1981.

39. R.N. Yong and B.P. Warkentin, Introduction to Soil Behavior, Macmillan, New York, 1966.

40. V.C. Rogers, "Ambient Soil Moistures in the Uranium Milling Region of the West," RAE Quarterly Progress Report to B-PNWL, March 1981.

41. Environmental Assessment Related to the Operation of Hansen Uranium Mill Project, NUREG-0749, January 1981. 

APPENDIX A

INPUT DATA FORMAT FOR RAECO PROGRAM

All input data is free format. The following input is needed for program operation.

Card Set Number

1

2
Card Description

Site Designation Card - One card with up to 80 characters which designates the tailings cover system and run identification.

Boundary Conditions and Cost Control Parameters - One card containing six parameter values, each separated by commas in the following order:

(1) N, Number of distinct Tailings cover Tayers: positive integer, presently limited to 99.

(2) Fol, Entrance radon flux to layer $1, \mathrm{pCi} / \mathrm{m}^{2} \mathrm{sec}$.

(3) CN1, Surface radon concentration at top of system, $p C i / 1$.

(4) ICOST, Integer Cost Flag, ICOST $=0$ if no cost or optimization is to be performed, I otherwise.

(5) CRITJ, Surface Flux Constraint for optimization, $\mathrm{pCi} / \mathrm{m} 2 \mathrm{sec}$. CRITJ $=0$ for no constraint.

(6) ACC, Surface Flux Convergence Criterion, fraction.

Individual Cover Layer Data Cards - One card for each tajlings or cover layer. Each card is composed of four parameters:

(1) DX, The layer thickness in $\mathrm{cm}$. 
(2) D, Layer effective radon diffusion coefficient, $\mathrm{cm}^{2} / \mathrm{sec}$.

(3) p, Layer porosity.

(4) Q, Layer radon source term in $\mathrm{pCi} / \mathrm{cm}^{3} \mathrm{sec}$.

4

5

6

$6_{\text {a }}$ (OPTIONAL)

$\sigma_{b} \quad$ (OPTIONAL)
Cost Control Alternative Flags and Tailings Area - One card composed of five numerical data fields each separated by commas in the following order:

(1) ICF, Cost Alternative Flag, integer where ICF $=0$ for cover costs only and 1 for total remedial action costs.

(2) IOPT, Alternative Type Flag, integer, where $I O P T=0$ for alternative in which tailings are not moved and 1 for moving alternative.

(3) TAREA, Total area of taitings pile (acres).

(4) DAREA, Total area of new tailings pile (acres) if $\mathrm{IOPT}=1$.

(5) ITRAN, Cover Haul cost Flag, integer, ITRAN $=0$ if cover haul costs not specified separately and 1 if they are.

Tailings Cover Unit Costs - This card contains C131 or C521 unit costs for each cover layer each separated by a comma $\left(\$ / \mathrm{yd}^{3}\right)$. (See Section 1.3 or 5.2 in Appendix B.) The layer costs appear on the card in order of ascending layer number.

Tailings Cover Soreading Unit Costs - This card contains unit costs for each cover layer, each separated by a comma $\left(\$ / y d^{3}\right)$, in ascending order (see Section 1.3 or 5.2 in Appendix B).

Cover Material Haul Unit Costs - This card is only needed if ITRAN $=1$. It contains Section 4.3 (Appendix B) unit costs for each cover layer ( $\$ /$ ton).

Cover Material Densities - This card is only needed if ITRAN = 1. It contains RHO, cover densities ( $\left.\mathrm{gm} / \mathrm{cm}^{3}\right)$ to convert cover haul unit costs from tons to $y d^{3}$.

Cover Support Costs - This card gives site support costs in doliars. The format of this card depends upon the value of IOPT (moving or nonmoving alternative). If IOPT $=0$, the paranieters are:

(1) Site Preparation (Section 1.1, Appendix B). 
(2) Tailings Pile Preparation.

(3) Site Leveling and Grading.

(4) Millsite Cleanup.

(5) Reclamation and Sprinkling (\$/acre).

(6) Fencing.

(7) Support Services.

(8) Miscellaneous Expenses.

If $I O P T=1$, the card contains the following cost parameters that pertain to the disposal site:

(1) Disposal Site Preparation and Fencing Costs.

(2) Clearing and Excavation.

(3) Tailings Placement Costs.

(4) Reclamation and Sprinkling Unit Costs $(\$ /$ acre $)$.

(5) Support Services.

(6) Miscellaneous Expenses.

Other Remedial Alternative Costs and Factors - This card is needed only if ICF $=1$. It contains six cost entries in dollars.

(1) Offsite Remedial Action Costs (Section 2, Appendix B).

(2) Windblown Tailings Area Remedial Action (Section 3, Appendix B) Costs.

(3) Iransportation Capital Costs (Section 4, Appendix B).

(4) Transportation HauT Costs.

(5) Engineering, Design and Construction Management Percentage Fee.

(6) Contingency Percentage. 
Card Set Number

9

Card Description

Optimization Constraint Card - The following five parameters are input in free format.

(1) Thickness Constraint Flag, Integer Format

$=0$ for no thickness constraints

$=1$ for minimum specified thickness, D2 above

$=2$ for minimum specified cover

$=12$ for both thickness constraints

(2) Minimum Thickness above Optimized Layer in $\mathrm{cm}$.

(3) Minimum Cover Thickness in cm.

(4) First Layer in 0ptimization, Integer.

(5) Second Layer in Optimization, Integer. 


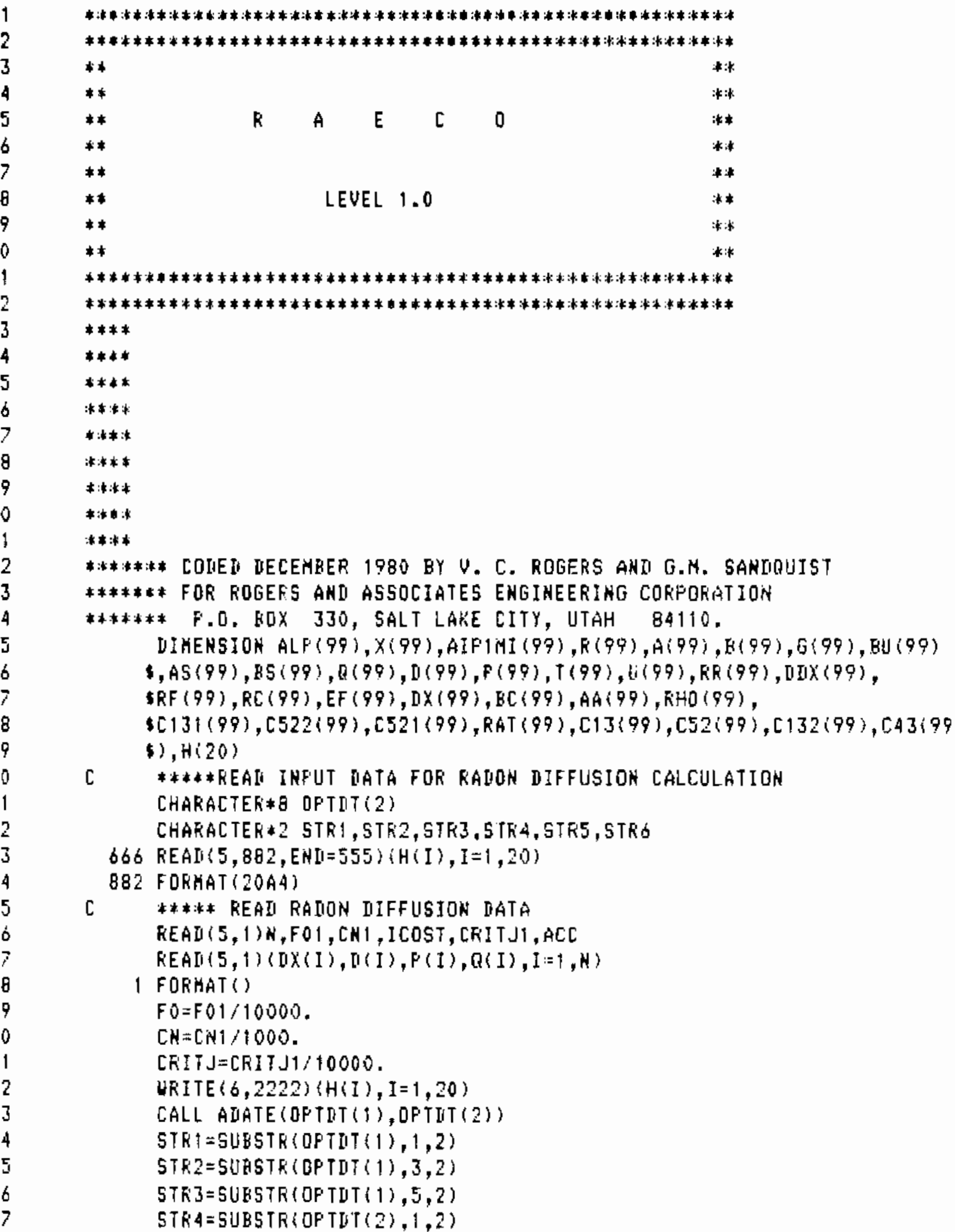




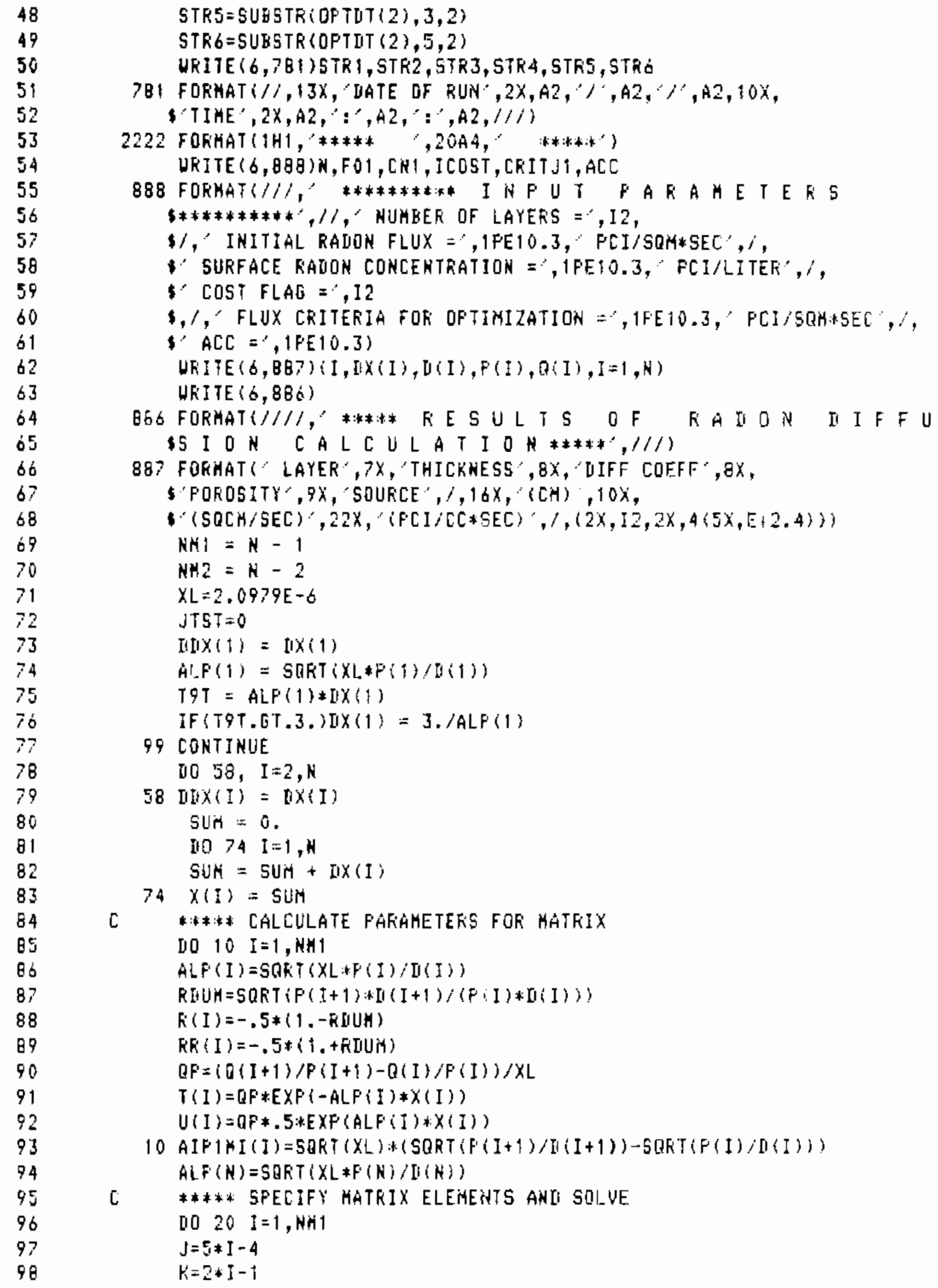




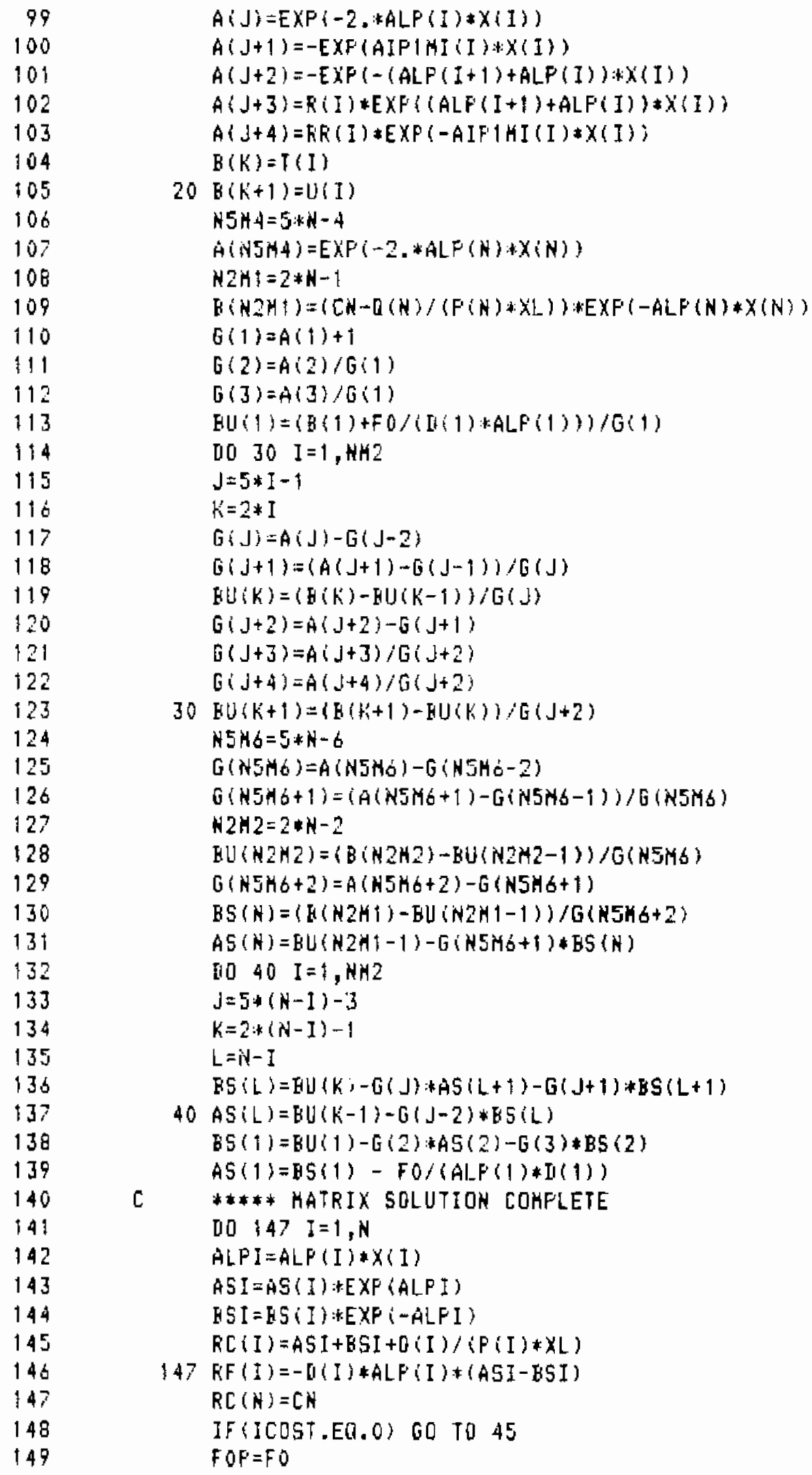




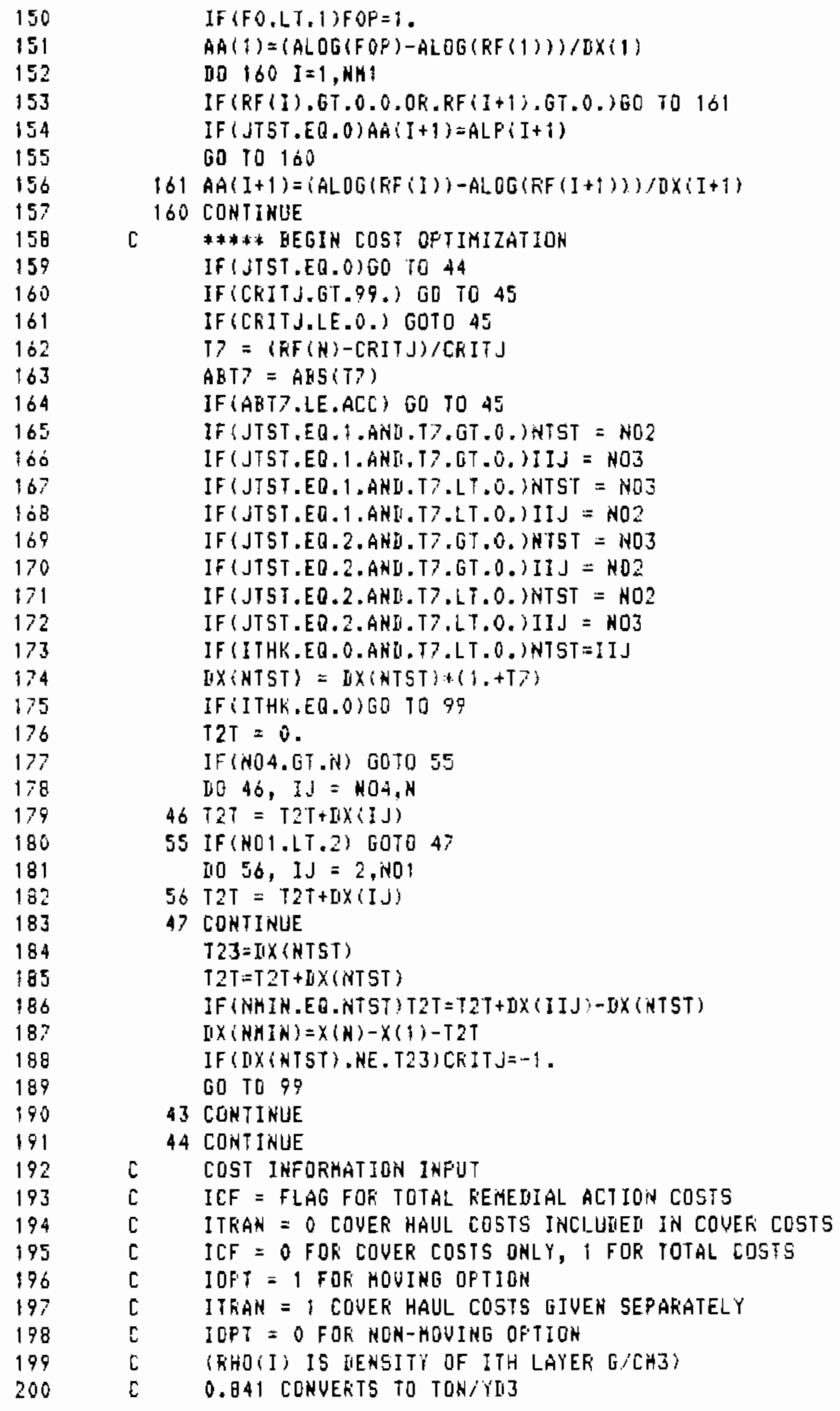




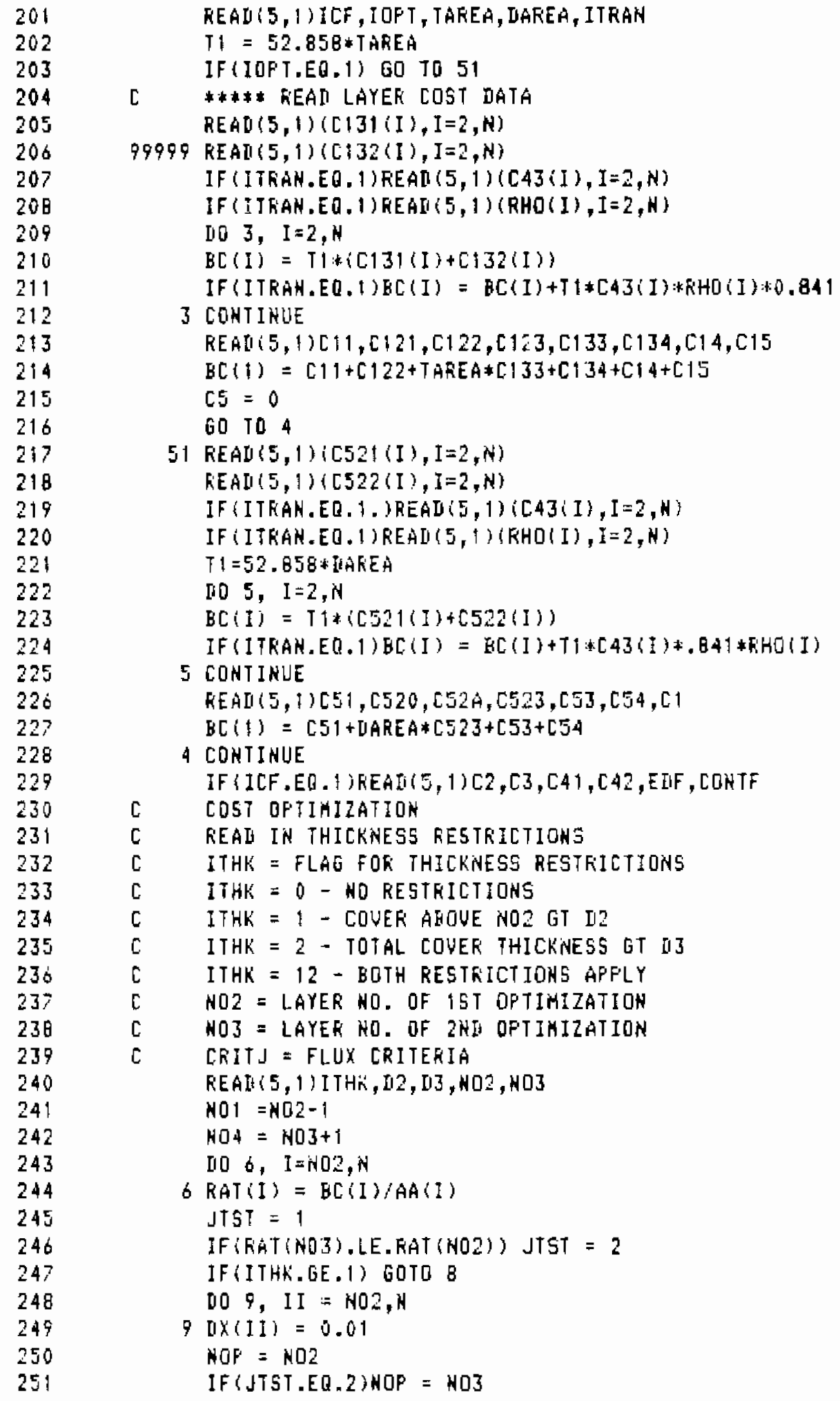




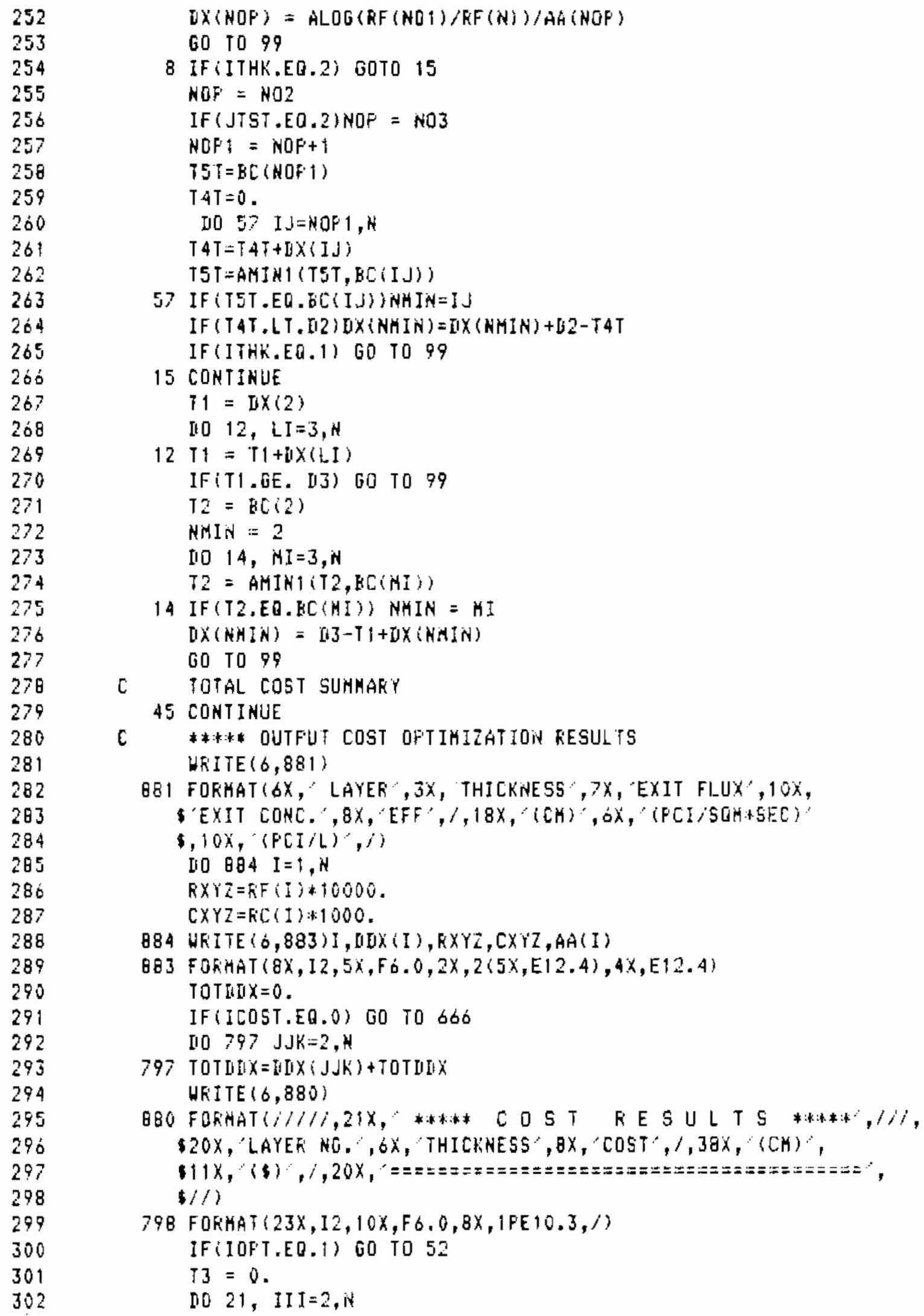




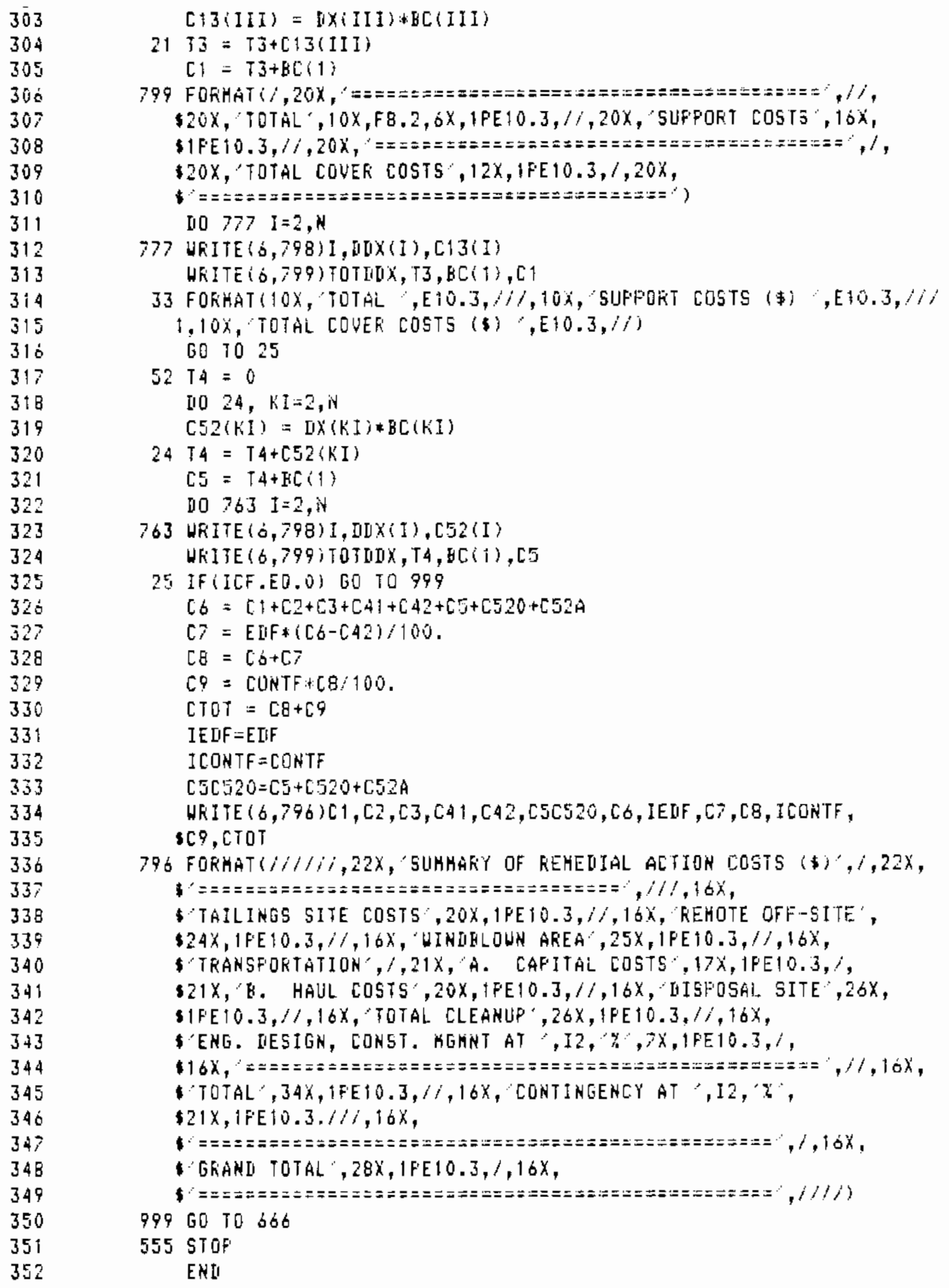

303

304

305

306

$30 \%$

308

309

310

311

312

313

314

315

316

317

318

319

320

321

322

323

324

325

326

327

328

329

330

331

332

333

334

335

336

337

338

339

340

341

342

343

344

345

346

347

348

349

350

351

352

CI3iIII $)=[1 \times$ IIII $) * B C($ III $)$

$2133=T 3+[13(111)$

$C 1=T 3+B C(1)$

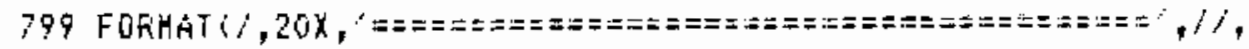

\$20X, TOTAL', $10 X, F 8.2,6 X, 1 P E 10.3, / /, 20 X$, SUFFORT COSTS", 16X,

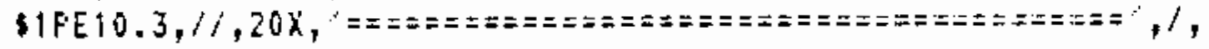

120X,'TDTAL COVEF COSTS $12 X, 1 F E 10.3,1,20 \mathrm{X}$,

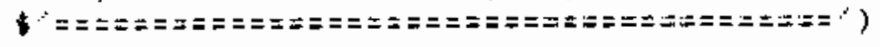

II $777 \quad 1=2, \mathrm{~N}$

777 WRITE $(6,798) 1,010 \times(1)$, C13(I)

HRITE(6,799)FOTIUX, T3, BC(1), C1

33 FOKHAT(10X, TOTAL , E $10.3, / /, 10 x$, SUFPORT COSTS (⿻) , E $\$ 0.3, / 1 /$

$1,10 x$, TOTAL COVEK COSTS ( $\$$ ) "E $10.3, \%$

GO 1025

52 T4 $=0$

II0 $24, K I=2$, iv

$C 52(K I)=D X(K I) * B C(K I)$

$24 T 4=T 4+C 52(K I)$

$C 5=T 4+H C(1)$

ग10 $2631=2$, it

763 URITE $(0,798) 1$, IVXX(I), C52(I)

WKIJE (6,799)TOJIDX, T4, HC(i), [5

25 IF IICF.EO.0) G0 TO 999

$C_{6}=[1+C 2+C 3+C 41+C 42+C 5+C 520+C 52 A$

$C 7=E[i F *(C 6-C 42) / 100$.

$C \theta=[\mathrm{C} b+\mathrm{CD}$

$C Q=$ CUNTF:CB/100.

CTOT $=C 8+[9$

IELF=EIIF

ICONTF=CONTF

$C 5 C 520=C 5+C 520+C 52 A$

WRITE $(6,796) C 1, C 2, C 3, C 41, C 42, C 5 C 520, C 6, I E U F, C 7, C 8, I C O N T F$, SC9,CTOT

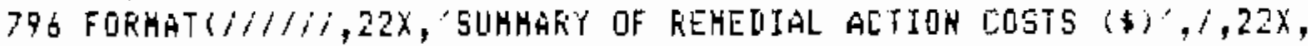

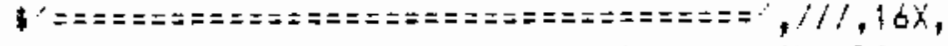

- tailings site costs , 20x,1fe10.3, $i /, 16 x$, RenOte off-site.,

324X,1FE10.3,1/,16X, UINIFLOUN AREA ,25X,1FE10.3,1/,16X,

"TRANSFORTATION, , $21 X$, a. CAFITAL COSTS , 17X,1FE10.3,;,

321X,'B. HAUL COSTS',20X, IFE10.3, $/ 1,16 X$, "ISFOSAL SITE',26X,

SFE10.3, $/ 1,16 \times$, TOTAL CLEANUP',26X,1FE10.3,1/,16X,

\$ENG. IIESIGN, CONST. MGHNT AT $, I 2, \%, 7 X, 1 F E 10.3,1$,

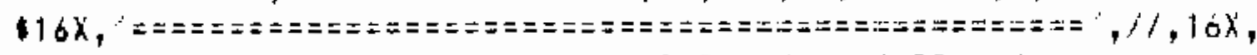

- total , 34X,tfeio.3, $/ 1,16 x$, contingency at ', $12, ' 3$,

\$21X, 1FE TO.3.//1, 16X,

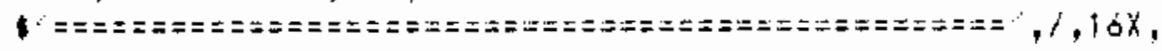

- GRAND TOTAL , 28X,1FE10.3,1,16X,

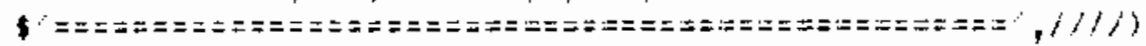

$999 \quad 60 \quad 10 \quad 666$

555 STOF'

ENII 

APPENDIX B

TABLES OF REQUIRED DEPTHS FOR RADON ATTENUATION

B-1 
TABLES OF REOUIREO OEPTHS FOR RADON ATFENUATION (METERS)

ORE GRADE IS .0S

TABLE B. 1

COVER HOISTURE ( $x$ ) /OIFFUSION COEFFICIENT (CM**Z PER SEC)

\begin{tabular}{|c|c|c|c|c|c|c|c|c|c|c|c|c|c|}
\hline $\begin{array}{l}\text { TAILINGS } \\
\text { MOISTURE }\end{array}$ & $\begin{array}{l}\text { DIFFUSION } \\
\text { COEFFICIENT }\end{array}$ & : $(x)$ & 5.0 & 6.0 & $\begin{array}{r}7.0 \\
-.0 .\end{array}$ & 0.0 & 9.0 & 10.0 & $\$ 1.0$ & 12.0 & 13.0 & 14.0 & 15.0 \\
\hline (x) & $(C M * n 2 / S E C)$ & - $D / P$ & .0287 & .022 & .017 & .0131 & .0101 & .007 & .0060 & .004 & .0036 & .0027 & .0021 \\
\hline $\begin{array}{l}3.0 \\
5.0 \\
6.0 \\
7.0 \\
8.0 \\
9.0 \\
10.0 \\
11.0 \\
12.0 \\
13.0 \\
14.0 \\
15.0\end{array}$ & $\begin{array}{l}.0484 \\
.0287 \\
.0221 \\
.0171 \\
.0131 \\
.0101 \\
.0078 \\
.0060 \\
.0046 \\
.0036 \\
.0027 \\
.0021\end{array}$ & : & $\begin{array}{l}4.9 \\
4.8 \\
9.7 \\
4.6 \\
4.5 \\
4.4 \\
4.3 \\
4.2 \\
4.1 \\
4.0 \\
3.9 \\
3.0\end{array}$ & $\begin{array}{l}4.3 \\
4.1 \\
4.1 \\
4.0 \\
3.9 \\
3.8 \\
3.8 \\
3.7 \\
3.6 \\
3.5 \\
3.4 \\
3.3\end{array}$ & $\begin{array}{l}3.7 \\
3.6 \\
3.5 \\
3.5 \\
3.4 \\
3.3 \\
3.3 \\
3.2 \\
3.1 \\
3.0 \\
2.9 \\
2.9\end{array}$ & $\begin{array}{l}3.2 \\
3.1 \\
3.0 \\
3.0 \\
2.9 \\
2.9 \\
2.8 \\
2.8 \\
2.7 \\
2.6 \\
2.6 \\
2.5\end{array}$ & $\begin{array}{l}2.7 \\
2.6 \\
2.6 \\
2.6 \\
2.5 \\
2.5 \\
2.4 \\
2.4 \\
2.3 \\
2.3 \\
2.2 \\
2.2\end{array}$ & $\begin{array}{l}2.3 \\
2.3 \\
2.2 \\
2.2 \\
2.2 \\
2.1 \\
2.1 \\
2.1 \\
2.0 \\
2.0 \\
1.9 \\
1.9\end{array}$ & $\begin{array}{l}2.0 \\
1.9 \\
1.9 \\
1.9 \\
1.9 \\
1.8 \\
1.8 \\
1.8 \\
1.7 \\
1.7 \\
1.7 \\
1.6\end{array}$ & $\begin{array}{l}1.7 \\
1.7 \\
1.6 \\
1.6 \\
1.6 \\
1.6 \\
1.6 \\
1.5 \\
1.5 \\
1.5 \\
1.4 \\
1.4\end{array}$ & $\begin{array}{l}1.4 \\
1.4 \\
1.4 \\
1.4 \\
1.4 \\
1.4 \\
1.3 \\
1.3 \\
1.3 \\
1.3 \\
1.2 \\
1.2\end{array}$ & $\begin{array}{l}1.2 \\
1.2 \\
1.2 \\
1.2 \\
1.2 \\
1.2 \\
1.1 \\
1.1 \\
1.1 \\
1.1 \\
1.1 \\
1.0\end{array}$ & $\begin{array}{l}1.0 \\
1.0 \\
1.0 \\
1.0 \\
1.0 \\
1.0 \\
1.0 \\
1.0 \\
.9 \\
.9 \\
.9 \\
.9\end{array}$ \\
\hline
\end{tabular}

ORE GRAOE IS

.06

TALE B. 2

COVER MOISTURE ( $x$ )/DIFFUSTON COEFFICIENT (CMA DE PER SEC)

\begin{tabular}{|c|c|c|c|c|c|c|c|c|c|c|c|c|c|}
\hline $\begin{array}{l}\text { TAILINGS } \\
\text { MOISTURE }\end{array}$ & $\begin{array}{l}\text { OIFFUSION } \\
\text { COEFFICIENY" }\end{array}$ & $:[x\}$ & 5.0 & 6.0 & 7.0 & 8.0 & 9.0 & 10.0 & 11.0 & 12.0 & 13.0 & 14.0 & $\begin{array}{l}15.0 \\
-150.0\end{array}$ \\
\hline (x) & $(C M \cap 2 / S E C)$ & - $D / P$ & $.02 B 7$ & .0221 & .0171 & .0131 & .0101 & .0078 & .0060 & .0046 & .0036 & .0027 & .0021 \\
\hline $\begin{array}{l}3.0 \\
5.0 \\
6.0 \\
7.0 \\
5.0 \\
9.0 \\
10.0 \\
11.0 \\
12.0 \\
13.0 \\
14.0 \\
15.0\end{array}$ & $\begin{array}{l}.0484 \\
.0287 \\
.0221 \\
.0171 \\
.0131 \\
.0101 \\
.0078 \\
.0060 \\
.0046 \\
.0036 \\
.0027 \\
.0021\end{array}$ & : & $\begin{array}{l}5.2 \\
5.0 \\
4.9 \\
4.8 \\
4.8 \\
4.7 \\
4.6 \\
4.5 \\
4.3 \\
4.2 \\
4.1 \\
4.0\end{array}$ & $\begin{array}{l}4.4 \\
4.3 \\
4.3 \\
4.2 \\
4.1 \\
4.0 \\
4.0 \\
3.9 \\
3.8 \\
3.7 \\
3.6 \\
3.5\end{array}$ & $\begin{array}{l}3.8 \\
3.7 \\
3.7 \\
3.6 \\
3.6 \\
3.5 \\
3.4 \\
3.4 \\
3.3 \\
3.2 \\
3.1 \\
3.0\end{array}$ & $\begin{array}{l}3.3 \\
3.2 \\
3.2 \\
3.1 \\
3.1 \\
3.0 \\
3.0 \\
2.9 \\
2.8 \\
2.8 \\
2.7 \\
2.6\end{array}$ & $\begin{array}{l}2.8 \\
2.8 \\
2.7 \\
2.7 \\
2.7 \\
2.6 \\
2.6 \\
2.5 \\
2.5 \\
2.4 \\
2.3 \\
2.3\end{array}$ & $\begin{array}{l}2.4 \\
2.4 \\
2.4 \\
2.3 \\
2.3 \\
2.3 \\
2.2 \\
2.2 \\
2.1 \\
2.1 \\
2.0 \\
2.0\end{array}$ & $\begin{array}{l}2.1 \\
2.0 \\
2.0 \\
2.0 \\
2.0 \\
1.9 \\
1.9 \\
1.9 \\
1.8 \\
1.8 \\
1.8 \\
1.7\end{array}$ & $\begin{array}{l}1.8 \\
1.8 \\
1.7 \\
1.7 \\
1.7 \\
1.7 \\
1.6 \\
1.6 \\
1.6 \\
1.5 \\
1.5 \\
1.5\end{array}$ & $\begin{array}{l}1.5 \\
1.5 \\
1.5 \\
1.5 \\
1.4 \\
1.4 \\
1.4 \\
1.4 \\
1.4 \\
1.3 \\
1.3 \\
1.3\end{array}$ & $\begin{array}{l}1.3 \\
1.3 \\
1.3 \\
1.3 \\
1.2 \\
1.2 \\
1.2 \\
1.2 \\
1.2 \\
1.1 \\
1.1 \\
1.1\end{array}$ & $\begin{array}{l}1.1 \\
1.1 \\
1.1 \\
1.1 \\
1.1 \\
1.0 \\
1.0 \\
1.0 \\
1.0 \\
1.0 \\
1.0 \\
.0\end{array}$ \\
\hline
\end{tabular}


TABLES OF REQUIRED DEPTHS FOR RAOON ATTENUATION (METENS)

TABLE B. 3

COVER MOISTURE ( $X$ )/DIFFUSION COEFFICIENT (CH\#\#Z PER SEC)

\begin{tabular}{|c|c|c|c|c|c|c|c|c|c|c|c|c|c|}
\hline $\begin{array}{l}\text { TAILINGS } \\
\text { MOISTURE } \\
(x)\end{array}$ & $\begin{array}{l}\text { DIFFUSTON } \\
\text { COEFFICIENT } \\
\text { (CHMZISEC) }\end{array}$ & $\begin{array}{l}(x) \\
: 0 / p\end{array}$ & $\begin{array}{r}5.0 \\
.0287\end{array}$ & $\begin{array}{c}6.0 \\
.0221\end{array}$ & $\begin{array}{c}7.0 \\
-0 ! 71\end{array}$ & $\begin{array}{r}8.0 \\
.0131\end{array}$ & $\begin{array}{r}9.0 \\
.0101\end{array}$ & $\begin{array}{l}10.0 \\
.0078\end{array}$ & $\begin{array}{l}11.0 \\
.0060\end{array}$ & $\begin{array}{l}12.0 \\
.0046\end{array}$ & $\begin{array}{l}13.0 \\
.0036\end{array}$ & $\begin{array}{l}14.0 \\
.0027\end{array}$ & $\begin{array}{l}15.0 \\
.0021\end{array}$ \\
\hline $\begin{array}{l}3.0 \\
5.0 \\
6.0 \\
7.0 \\
8.0 \\
9.0 \\
10.0 \\
11.0 \\
12.0 \\
13.0 \\
14.0 \\
15.0\end{array}$ & $\begin{array}{l}.0484 \\
.0287 \\
.0221 \\
.0171 \\
.0131 \\
.0101 \\
.0078 \\
.0060 \\
.0046 \\
.0036 \\
.0027 \\
.0021\end{array}$ & : & $\begin{array}{l}5.5 \\
5.4 \\
5.3 \\
5.2 \\
5.1 \\
5.0 \\
9.9 \\
4.8 \\
4.7 \\
9.6 \\
9.5 \\
4.3\end{array}$ & $\begin{array}{l}4.7 \\
0.6 \\
4.6 \\
4.5 \\
4.4 \\
4.3 \\
4.3 \\
4.2 \\
4.1 \\
4.0 \\
3.9 \\
3.8\end{array}$ & $\begin{array}{l}4.1 \\
4.0 \\
3.9 \\
3.9 \\
3.8 \\
3.8 \\
3.7 \\
3.6 \\
3.5 \\
3.5 \\
3.4 \\
3.3\end{array}$ & $\begin{array}{l}3.5 \\
3.5 \\
3.4 \\
3.4 \\
3.3 \\
3.3 \\
3.2 \\
3.1 \\
3.1 \\
3.0 \\
2.9 \\
2.9\end{array}$ & $\begin{array}{l}3.0 \\
3.0 \\
2.9 \\
2.9 \\
2.9 \\
2.8 \\
2.8 \\
2.7 \\
2.7 \\
2.6 \\
2.5 \\
2.5\end{array}$ & $\begin{array}{l}2.6 \\
2.6 \\
2.5 \\
2.5 \\
2.5 \\
2.4 \\
2.4 \\
2.3 \\
2.3 \\
2.3 \\
2.2 \\
2.2\end{array}$ & $\begin{array}{l}2.2 \\
2.2 \\
2.2 \\
2.2 \\
2.1 \\
2.1 \\
2.1 \\
2.0 \\
2.0 \\
2.0 \\
1.9 \\
1.9\end{array}$ & $\begin{array}{l}1.9 \\
1.9 \\
1.9 \\
1.8 \\
1.8 \\
1.8 \\
1.8 \\
1.7 \\
1.7 \\
1.7 \\
1.7 \\
1.6\end{array}$ & $\begin{array}{l}1.6 \\
1.6 \\
1.6 \\
1.6 \\
1.6 \\
1.5 \\
1.5 \\
1.5 \\
1.5 \\
1.5 \\
1.4 \\
1.4\end{array}$ & $\begin{array}{l}1.4 \\
1.4 \\
1.4 \\
1.4 \\
1.3 \\
1.3 \\
1.3 \\
1.3 \\
1.3 \\
1.3 \\
1.2 \\
1.2\end{array}$ & $\begin{array}{l}1.2 \\
1.2 \\
1.2 \\
1.2 \\
1.2 \\
1.1 \\
1.1 \\
1.1 \\
1.1 \\
1.1 \\
1.1 \\
1.0\end{array}$ \\
\hline
\end{tabular}

ORE GRAOE IS .10

TABLE B.

COVER MOISTURE ( $X$ )/DIFFUSION COEFFICIENT (CM*\#Z PER SEC)

\begin{tabular}{|c|c|c|c|c|c|c|c|c|c|c|c|c|c|}
\hline $\begin{array}{l}\text { TAILINGS } \\
\text { MOISTURE }\end{array}$ & $\begin{array}{l}\text { DIFFUSION } \\
\text { COEFFICIENT }\end{array}$ & $\therefore(x)$ & 5.0 & 6.0 & $\begin{array}{r}7.0 \\
-0 *+1\end{array}$ & 8.0 & 9.0 & 10.0 & 11.0 & 12.0 & 13.0 & 10.0 & $\begin{array}{r}15.0 \\
-10.0\end{array}$ \\
\hline$(x)$ & $\left(C M_{n \rightarrow Z}=\mathrm{SEC}\right)$ & $10 / P$ & .0287 & .0221 & .017 & .0131 & .010 & .007 & .0060 & .0046 & .003 & .0027 & .0021 \\
\hline $\begin{array}{r}3.0 \\
5.0 \\
6.0 \\
7.0 \\
8.0 \\
9.0 \\
10.0 \\
11.0 \\
12.0 \\
13.0 \\
14.0 \\
15.0\end{array}$ & $\begin{array}{l}.0484 \\
.0287 \\
.0221 \\
.0171 \\
.0131 \\
.0101 \\
.0078 \\
.0860 \\
.0046 \\
.0036 \\
.0027 \\
.0021\end{array}$ & : & $\begin{array}{l}5.8 \\
5.6 \\
5.5 \\
5.5 \\
5.4 \\
5.3 \\
5.2 \\
5.1 \\
5.0 \\
4.8 \\
4.7 \\
4.6\end{array}$ & $\begin{array}{l}5.0 \\
4.9 \\
4.8 \\
4.7 \\
4.7 \\
4.6 \\
9.5 \\
4.4 \\
4.3 \\
4.2 \\
4.1 \\
4.0\end{array}$ & $\begin{array}{l}4.3 \\
4.2 \\
4.2 \\
4.1 \\
9.0 \\
4.0 \\
3.9 \\
3.8 \\
3.7 \\
3.7 \\
3.6 \\
3.5\end{array}$ & $\begin{array}{l}3.7 \\
3.6 \\
3.6 \\
3.5 \\
3.5 \\
3.4 \\
3.4 \\
3.3 \\
3.3 \\
3.2 \\
3.1 \\
3.0\end{array}$ & $\begin{array}{l}3.2 \\
3.1 \\
3.1 \\
3.1 \\
3.0 \\
3.0 \\
2.9 \\
2.9 \\
2.8 \\
2.8 \\
2.7 \\
2.6\end{array}$ & $\begin{array}{l}2.7 \\
2.7 \\
2.7 \\
2.6 \\
2.6 \\
2.6 \\
2.5 \\
2.5 \\
2.4 \\
2.4 \\
2.3 \\
2.3\end{array}$ & $\begin{array}{l}2.4 \\
2.3 \\
2.3 \\
2.3 \\
2.2 \\
2.2 \\
2.2 \\
2.2 \\
2.1 \\
2.1 \\
2.0 \\
2.0\end{array}$ & $\begin{array}{l}2.0 \\
2.0 \\
2.0 \\
2.0 \\
1.9 \\
1.9 \\
1.9 \\
1.9 \\
1.8 \\
1.8 \\
1.8 \\
1.7\end{array}$ & $\begin{array}{l}1.7 \\
1.7 \\
1.7 \\
1.7 \\
1.7 \\
1.6 \\
1.6 \\
1.6 \\
1.6 \\
1.5 \\
1.5 \\
1.5\end{array}$ & $\begin{array}{l}1.5 \\
1.5 \\
1.5 \\
1.4 \\
1.4 \\
1.4 \\
1.4 \\
1.4 \\
1.4 \\
1.3 \\
1.3 \\
1.3\end{array}$ & $\begin{array}{l}1.3 \\
1.3 \\
1.2 \\
1.2 \\
1.2 \\
1.2 \\
1.2 \\
1.2 \\
1.2 \\
1.1 \\
1.1 \\
1.1\end{array}$ \\
\hline
\end{tabular}


TABLES OF REQUIRED DEPTHS FOR HADON ATTENIATION (METERS)

ORE GRADE IS .12

TABLE B. 5

COVER MOISTURE ( $x$ ) /OIFFUSION COEFFICIENT (CH\#\#Z PER SFC)

\begin{tabular}{|c|c|c|c|c|c|c|c|c|c|c|c|c|c|}
\hline $\begin{array}{l}\text { THILINGS } \\
\text { MOISTURE }\end{array}$ & $\begin{array}{l}\text { DIFFUSION } \\
\text { COEFFICIENT }\end{array}$ & ; $(x)$ & 5.0 & 6.0 & 7.0 & B. 0 & 9.0 & 10.0 & 11.0 & 12.0 & 13.0 & 14.0 & 15.0 \\
\hline$(x)$ & (CM**2/SEC) & $10 / P$ & .0287 & .0221 & .0171 & .0131 & .0101 & .0078 & .0060 & .0046 & .0036 & .0027 & .0021 \\
\hline $\begin{array}{l}3.0 \\
5.0 \\
6.0 \\
7.0 \\
8.0 \\
9.0 \\
10.0 \\
11.0 \\
12.0 \\
13.0 \\
19.0 \\
15.0\end{array}$ & $\begin{array}{l}.0489 \\
.0287 \\
.0221 \\
.0171 \\
.0131 \\
.0101 \\
.0078 \\
.0060 \\
.0046 \\
.0036 \\
.0027 \\
.0021\end{array}$ & : & $\begin{array}{l}6.0 \\
5.8 \\
5.8 \\
5.7 \\
5.6 \\
5.5 \\
5.4 \\
5.3 \\
5.2 \\
5.1 \\
4.9 \\
4.8\end{array}$ & $\begin{array}{l}5.2 \\
5.1 \\
5.0 \\
4.9 \\
4.9 \\
4.8 \\
9.7 \\
4.6 \\
4.5 \\
4.9 \\
4.3 \\
4.2\end{array}$ & $\begin{array}{l}4.5 \\
4.4 \\
4.3 \\
4.3 \\
4.2 \\
4.1 \\
4.1 \\
4.0 \\
3.9 \\
3.8 \\
3.8 \\
3.7\end{array}$ & $\begin{array}{l}3.9 \\
3.8 \\
3.7 \\
3.7 \\
3.6 \\
3.6 \\
3.5 \\
3.5 \\
3.4 \\
3.3 \\
3.3 \\
3.2\end{array}$ & $\begin{array}{l}3.3 \\
3.3 \\
3.2 \\
3.2 \\
3.1 \\
3.1 \\
3.1 \\
3.0 \\
3.0 \\
2.9 \\
2.8 \\
2.8\end{array}$ & $\begin{array}{l}2.9 \\
2.8 \\
2.8 \\
2.8 \\
2.7 \\
2.7 \\
2.6 \\
2.6 \\
2.6 \\
2.5 \\
2.5 \\
2.4\end{array}$ & $\begin{array}{l}2.5 \\
2.4 \\
2.4 \\
2.4 \\
2.3 \\
2.3 \\
2.3 \\
2.2 \\
2.2 \\
2.2 \\
2.1 \\
2.1\end{array}$ & $\begin{array}{l}2.1 \\
2.1 \\
2.1 \\
2.0 \\
2.0 \\
2.0 \\
2.0 \\
1.9 \\
1.9 \\
1.9 \\
1.9 \\
1.9\end{array}$ & $\begin{array}{l}1.8 \\
1.8 \\
1.8 \\
1.8 \\
1.7 \\
1.7 \\
1.7 \\
1.7 \\
1.7 \\
1.6 \\
1.6 \\
1.6\end{array}$ & $\begin{array}{l}1.5 \\
1.5 \\
1.5 \\
1.5 \\
1.5 \\
1.5 \\
1.5 \\
1.4 \\
1.4 \\
1.4 \\
1.4 \\
1.4\end{array}$ & $\begin{array}{l}1.3 \\
1.3 \\
1.3 \\
1.3 \\
1.3 \\
1.3 \\
1.3 \\
1.2 \\
1.2 \\
1.2 \\
1.2 \\
1.2\end{array}$ \\
\hline
\end{tabular}

ORE GRLOE IS

.14

TABLE B, 6

COVER MOISTURE ( $X$ ) IDIFFUSION COEFFICIENT (CM* 2 PER SEC)

\begin{tabular}{|c|c|c|c|c|c|c|c|c|c|c|c|c|c|}
\hline TAILINGS & DIFFUSION & ( (x) & 5.0 & 6.0 & 7.0 & 8.0 & 9.0 & 10.0 & 11.0 & 12.0 & 13.0 & 14.0 & 15.0 \\
\hline $\begin{array}{l}\text { OIST URE } \\
(x)\end{array}$ & $\begin{array}{l}\text { COEFFICIENY } \\
(C M * 2 / S E C)\end{array}$ & $: \overline{0}$ & .0287 & .0221 & .0171 & .0131 & .0101 & .0078 & .0060 & .0046 & $.003 t$ & .0027 & .0021 \\
\hline $\begin{array}{l}3.0 \\
5.0 \\
6.0 \\
7.0 \\
8.0 \\
9.0 \\
10.0 \\
11.0 \\
12.0 \\
13.0 \\
19.0 \\
15.0\end{array}$ & $\begin{array}{l}.0484 \\
.0287 \\
.0221 \\
.0171 \\
.0131 \\
.0101 \\
.0078 \\
.0060 \\
.0046 \\
.0036 \\
.0027 \\
.0021\end{array}$ & : & $\begin{array}{l}6.2 \\
6.0 \\
5.9 \\
5.9 \\
5.8 \\
5.7 \\
5.6 \\
5.5 \\
5.4 \\
5.2 \\
5.1 \\
5.0\end{array}$ & $\begin{array}{l}5.3 \\
5.2 \\
5.1 \\
5.1 \\
5.0 \\
4.9 \\
4.8 \\
9.8 \\
4.7 \\
4.6 \\
4.5 \\
4.4\end{array}$ & $\begin{array}{l}9.6 \\
4.5 \\
4.5 \\
9.9 \\
4.3 \\
4.3 \\
4.2 \\
4.1 \\
9.1 \\
4.0 \\
3.9 \\
3.8\end{array}$ & $\begin{array}{l}4.0 \\
3.9 \\
3.9 \\
3.8 \\
3.8 \\
3.7 \\
3.6 \\
3.6 \\
3.5 \\
3.5 \\
3.4 \\
3.3\end{array}$ & $\begin{array}{l}3.4 \\
3.4 \\
3.3 \\
3.3 \\
3.3 \\
3.2 \\
3.2 \\
3.1 \\
3.1 \\
3.0 \\
2.9 \\
2.9\end{array}$ & $\begin{array}{l}3.0 \\
2.9 \\
2.9 \\
2.8 \\
2.8 \\
2.8 \\
2.7 \\
2.7 \\
2.7 \\
2.6 \\
2.6 \\
2.5\end{array}$ & $\begin{array}{l}2.5 \\
2.5 \\
2.5 \\
2.5 \\
2.4 \\
2.4 \\
2.4 \\
2.3 \\
2.3 \\
2.3 \\
2.2 \\
2.2\end{array}$ & $\begin{array}{l}2.2 \\
2.2 \\
2.1 \\
2.1 \\
2.1 \\
2.1 \\
2.0 \\
2.0 \\
2.0 \\
2.0 \\
1.9 \\
1.9\end{array}$ & $\begin{array}{l}1.9 \\
1.9 \\
1.8 \\
1.8 \\
1.8 \\
1.8 \\
1.8 \\
1.7 \\
1.7 \\
1.7 \\
1.7 \\
1.6\end{array}$ & $\begin{array}{l}1.6 \\
1.6 \\
1.0 \\
1.6 \\
1.5 \\
1.5 \\
1.5 \\
1.5 \\
1.5 \\
1.5 \\
1.4 \\
1.4\end{array}$ & $\begin{array}{l}1.4 \\
1.4 \\
1.4 \\
1.3 \\
1.3 \\
1.3 \\
1.3 \\
1.3 \\
1.3 \\
1.3 \\
1.2 \\
1.2\end{array}$ \\
\hline
\end{tabular}


TAGLES OF REULIREO LEPTHS FOR RAOUN ATTENUATICN (METERG)

DRE GRADE IS

TASLE B. 7

COVER MOISTURE (

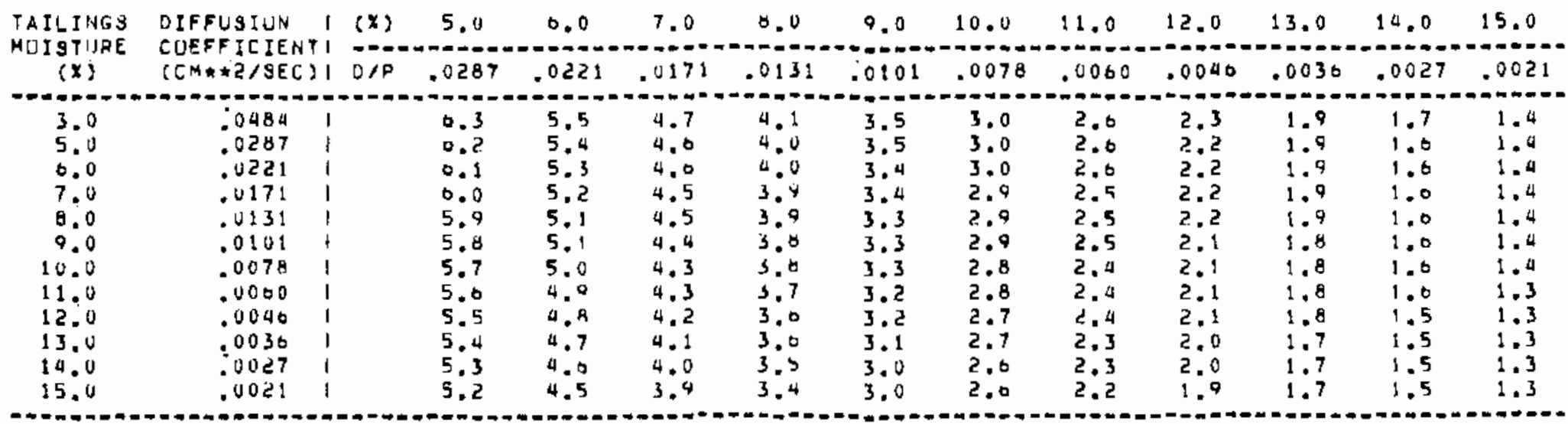

CRE GRADE IS . 18

TAOLE B. 8

CUVER MOISTURE ( $($ ) NIFFUgIUN COEFFICIENT (CM\#\#2 PER SEC)

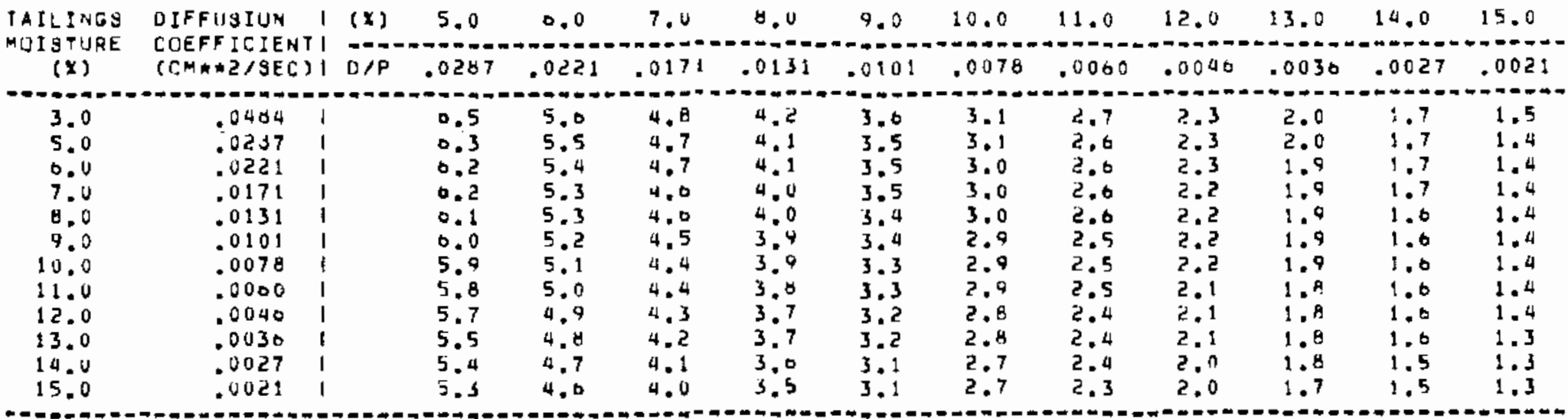


TABLES UF REOUIRED LEPTHS F(IR RAUON ATTENUATION (HETFRS)

DRE TRAAE IS .20

TAULE B.

COYER AIISTURE ( $X$ ) LIFFUSION COEFFICIENT (CM\#Z PER SEC)

\begin{tabular}{|c|c|c|c|c|c|c|c|c|c|c|c|c|c|c|}
\hline $\begin{array}{l}\text { TAILINGS } \\
\text { MOISTURE }\end{array}$ & $\begin{array}{l}\text { DIFFUSIUN } \\
\text { CUEFFIC:ENT }\end{array}$ & 1 & (x) & 5.0 & 0.0 & 7.0 & $\begin{array}{r}0.0 \\
-. .-2\end{array}$ & 9.0 & 10.0 & 11.0 & $\begin{array}{r}13.0 \\
-1-2=0\end{array}$ & 13.0 & 14.0 & 15.0 \\
\hline (x) & $(\mathrm{CH} \pitchfork 2 / \mathrm{HEC})$ & 1 & $0 / P$ & .028 & .022 & .0172 & .013 & .010 & .007 & .006 & .0040 & .0036 & .0027 & .0021 \\
\hline $\begin{array}{l}3.0 \\
5.0 \\
0.0 \\
7.0 \\
8.0 \\
9.0 \\
10.0 \\
11.0 \\
12.0 \\
13.0 \\
14.0 \\
15.0\end{array}$ & $\begin{array}{l}.0484 \\
.0287 \\
.0221 \\
.0171 \\
.0131 \\
.0101 \\
.0078 \\
.0000 \\
.0040 \\
.00330 \\
.0027 \\
.0021\end{array}$ & $\begin{array}{l}1 \\
1 \\
1 \\
1 \\
1 \\
1 \\
1 \\
1 \\
1 \\
1\end{array}$ & & $\begin{array}{l}0.0 \\
0.4 \\
0.4 \\
0.3 \\
0.2 \\
0.1 \\
0.0 \\
5.8 \\
5.8 \\
5.7 \\
5.0 \\
5.4\end{array}$ & $\begin{array}{l}5.7 \\
5.6 \\
5.5 \\
5.5 \\
5.4 \\
5.3 \\
5.2 \\
5.1 \\
5.0 \\
4.9 \\
4.8 \\
4.7\end{array}$ & $\begin{array}{l}4.9 \\
4.8 \\
4.8 \\
4.7 \\
4.7 \\
4.0 \\
4.5 \\
4.5 \\
4.4 \\
4.3 \\
4.2 \\
4.1\end{array}$ & $\begin{array}{r}4.3 \\
4.2 \\
4.1 \\
4.1 \\
4.0 \\
4.0 \\
3.9 \\
3.9 \\
3.0 \\
3.7 \\
3.7 \\
3.0\end{array}$ & $\begin{array}{l}3.7 \\
3.0 \\
3.0 \\
3.5 \\
3.5 \\
3.5 \\
3.4 \\
3.4 \\
3.3 \\
3.3 \\
3.2 \\
3.1\end{array}$ & $\begin{array}{l}3.2 \\
3.1 \\
3.1 \\
3.1 \\
3.0 \\
3.0 \\
3.0 \\
2.9 \\
2.9 \\
2.8 \\
2.8 \\
2.7\end{array}$ & $\begin{array}{l}2.7 \\
2.7 \\
2.7 \\
2.7 \\
2.6 \\
2.6 \\
2.6 \\
2.5 \\
2.5 \\
2.5 \\
2.4 \\
2.4\end{array}$ & $\begin{array}{l}2.4 \\
2.3 \\
2.3 \\
2.3 \\
2.3 \\
2.2 \\
2.2 \\
2.2 \\
2.2 \\
2.1 \\
2.1 \\
2.1\end{array}$ & $\begin{array}{l}2.0 \\
2.0 \\
2.0 \\
2.0 \\
2.0 \\
1.9 \\
1.9 \\
1.9 \\
1.9 \\
1.8 \\
1.8 \\
1.8\end{array}$ & $\begin{array}{l}1.7 \\
1.7 \\
1.7 \\
1.7 \\
1.7 \\
1.7 \\
1.7 \\
1.6 \\
1.6 \\
1.6 \\
1.0 \\
1.5\end{array}$ & $\begin{array}{l}1.5 \\
1.5 \\
1.5 \\
1.5 \\
1.4 \\
1.4 \\
1.4 \\
1.4 \\
1.4 \\
1.4 \\
1.4 \\
1.3\end{array}$ \\
\hline
\end{tabular}

ORE GRADE IS

.25

TABLE B.10

CUYER MUISTURE ( $x$ )/CIFFUSION COEFFICIENT (CM*\#Z PER SEC)

\begin{tabular}{|c|c|c|c|c|c|c|c|c|c|c|c|c|c|c|}
\hline $\begin{array}{l}\text { TAILINGS } \\
\text { MOISTIURE } \\
(x)\end{array}$ & $\begin{array}{l}\text { OIFFUYION } \\
\text { COEFFICIENT } \\
\text { (CH*\#己/SEC) }\end{array}$ & 1 & $\begin{array}{l}(x) \\
0-2 \\
0 / p\end{array}$ & $\begin{aligned} 5.0 \\
.0287\end{aligned}$ & $\begin{array}{r}0.0 \\
.0221 \\
.02\end{array}$ & $\begin{aligned} 7.0 \\
.0171\end{aligned}$ & $\begin{array}{r}0.0 \\
.0131\end{array}$ & $\begin{array}{r}9.0 \\
-.0101\end{array}$ & $\begin{array}{l}10.0 \\
.0078\end{array}$ & .0060 & $\begin{array}{l}12.0 \\
.0040\end{array}$ & $\begin{array}{l}13.0 \\
.0036\end{array}$ & $\begin{array}{l}10.0 \\
.00227\end{array}$ & $\begin{array}{l}15.0 \\
.0021\end{array}$ \\
\hline $\begin{array}{l}3.0 \\
5.0 \\
0.0 \\
7.0 \\
8.0 \\
9.0 \\
10.0 \\
11.0 \\
12.0 \\
13.0 \\
14.0 \\
15.0\end{array}$ & $\begin{array}{l}.0484 \\
.0287 \\
.0221 \\
.0171 \\
.0131 \\
.0101 \\
.0075 \\
.0000 \\
.0040 \\
.0036 \\
.0027 \\
.0021\end{array}$ & $\begin{array}{l}1 \\
1 \\
1 \\
1 \\
1 \\
1 \\
1 \\
1 \\
1 \\
1 \\
1\end{array}$ & & $\begin{array}{l}0.9 \\
0.7 \\
0.0 \\
0.5 \\
0.5 \\
0.4 \\
0.3 \\
0.2 \\
6.0 \\
5.9 \\
5.8 \\
5.7\end{array}$ & $\begin{array}{l}5.9 \\
5.8 \\
5.8 \\
5.7 \\
5.6 \\
5.5 \\
5.4 \\
5.4 \\
5.3 \\
5.2 \\
5.1 \\
5.0\end{array}$ & $\begin{array}{l}5.1 \\
5.0 \\
5.0 \\
4.9 \\
4.9 \\
4.8 \\
4.7 \\
4.7 \\
4.0 \\
4.5 \\
4.4 \\
4.3\end{array}$ & $\begin{array}{l}4.4 \\
4.4 \\
4.3 \\
4.3 \\
4.2 \\
4.2 \\
4.1 \\
4.1 \\
4.0 \\
3.4 \\
3.4 \\
3.4\end{array}$ & $\begin{array}{l}3.8 \\
3.8 \\
3.7 \\
3.7 \\
3.7 \\
3.6 \\
3.0 \\
3.5 \\
3.5 \\
3.4 \\
3.4 \\
3.3\end{array}$ & $\begin{array}{l}3.3 \\
3.3 \\
3.2 \\
3.2 \\
3.2 \\
3.1 \\
3.1 \\
3.1 \\
3.0 \\
3.0 \\
2.0 \\
2.9\end{array}$ & $\begin{array}{l}2.9 \\
2.8 \\
2.8 \\
2.8 \\
2.7 \\
2.7 \\
2.7 \\
2.7 \\
2.0 \\
2.6 \\
2.5 \\
2.5\end{array}$ & $\begin{array}{l}2.5 \\
2.4 \\
2.4 \\
2.4 \\
2.4 \\
2.3 \\
2.3 \\
2.3 \\
2.3 \\
2.2 \\
2.2 \\
2.2\end{array}$ & $\begin{array}{l}2.1 \\
2.1 \\
2.1 \\
2.1 \\
2.0 \\
2.0 \\
2.0 \\
2.0 \\
2.0 \\
1.9 \\
1.9 \\
1.9\end{array}$ & $\begin{array}{l}1.8 \\
1.8 \\
1.8 \\
1.8 \\
1.8 \\
1.8 \\
1.7 \\
1.7 \\
1.7 \\
1.7 \\
1.7 \\
1.6\end{array}$ & $\begin{array}{l}1.6 \\
1.6 \\
1.5 \\
1.5 \\
1.5 \\
1.5 \\
1.5 \\
1.5 \\
1.5 \\
1.4 \\
1.4 \\
1.4\end{array}$ \\
\hline
\end{tabular}


TABLES OF REQUIREO DEPTHS FOR RADUN ATTENUATION (METERS)

ORE GRADE IS

.30
TABLE B.1

COVER MOISTURE ( $x$ ) /DIFFUSION COEFFICIFRT (CM**Z PER SEC)

\begin{tabular}{|c|c|c|c|c|c|c|c|c|c|c|c|c|c|}
\hline $\begin{array}{l}\text { TAILINGS } \\
\text { MOISTURE }\end{array}$ & $\begin{array}{l}\text { OIFFUSION } \\
\text { COEFFICIENT }\end{array}$ & $:(x)$ & 5.0 & 6.0 & 7.0 & 8.0 & 9.0 & 10.0 & 11.0 & 12.0 & 13.0 & 14.0 & $\begin{array}{l}15.0 \\
-1.0-\end{array}$ \\
\hline (x) & $(C M=2 / S E C)$ & - $O / P$ & .0287 & .0221 & .0171 & .0131 & .0101 & $.007 \mathrm{~A}$ & .0060 & .0046 & .0036 & .0027 & .0021 \\
\hline $\begin{array}{r}3.0 \\
5.0 \\
6.0 \\
7.0 \\
8.0 \\
9.0 \\
10.0 \\
11.0 \\
12.0 \\
13.0 \\
10.0 \\
15.0\end{array}$ & $\begin{array}{l}.0484 \\
.0287 \\
.0221 \\
.0171 \\
.0131 \\
.0101 \\
.0078 \\
.0060 \\
.0046 \\
.0036 \\
.0027 \\
.0021\end{array}$ & : & $\begin{array}{l}7.1 \\
6.9 \\
6.8 \\
6.8 \\
6.7 \\
6.6 \\
6.5 \\
6.4 \\
6.3 \\
6.2 \\
6.0 \\
5.9\end{array}$ & $\begin{array}{l}6.1 \\
6.0 \\
5.9 \\
5.9 \\
5.8 \\
5.7 \\
5.6 \\
5.6 \\
5.5 \\
5.4 \\
5.3 \\
5.2\end{array}$ & $\begin{array}{l}5.3 \\
5.2 \\
5.2 \\
5.2 \\
5.0 \\
5.0 \\
4.9 \\
4.8 \\
4.8 \\
4.7 \\
4.6 \\
9.5\end{array}$ & $\begin{array}{l}4.6 \\
4.5 \\
4.5 \\
4.4 \\
4.4 \\
4.3 \\
4.3 \\
4.2 \\
4.1 \\
4.1 \\
4.0 \\
3.9\end{array}$ & $\begin{array}{l}4.0 \\
3.9 \\
3.9 \\
3.8 \\
3.8 \\
3.7 \\
3.7 \\
3.7 \\
3.6 \\
3.5 \\
3.5 \\
3.4\end{array}$ & $\begin{array}{l}3.4 \\
3.4 \\
3.4 \\
3.3 \\
3.3 \\
3.3 \\
3.2 \\
3.2 \\
3.1 \\
3.1 \\
3.0 \\
3.0\end{array}$ & $\begin{array}{l}3.0 \\
2.9 \\
2.9 \\
2.9 \\
2.8 \\
2.8 \\
2.8 \\
2.7 \\
2.7 \\
2.7 \\
2.6 \\
2.6\end{array}$ & $\begin{array}{l}2.6 \\
2.5 \\
2.5 \\
2.5 \\
2.5 \\
2.4 \\
2.4 \\
2.4 \\
2.4 \\
2.3 \\
2.3 \\
2.2\end{array}$ & $\begin{array}{l}2.2 \\
2.2 \\
2.2 \\
2.1 \\
2.1 \\
2.1 \\
2.1 \\
2.1 \\
2.0 \\
2.0 \\
2.0 \\
2.0\end{array}$ & $\begin{array}{l}1.9 \\
1.9 \\
1.9 \\
1.8 \\
1.8 \\
1.8 \\
1.8 \\
1.8 \\
1.8 \\
1.7 \\
1.7 \\
1.7\end{array}$ & $\begin{array}{l}1.6 \\
1.5 \\
1.5 \\
1.6 \\
1.5 \\
1.5 \\
1.6 \\
1.5 \\
1.5 \\
1.5 \\
1.5 \\
1.5\end{array}$ \\
\hline
\end{tabular}





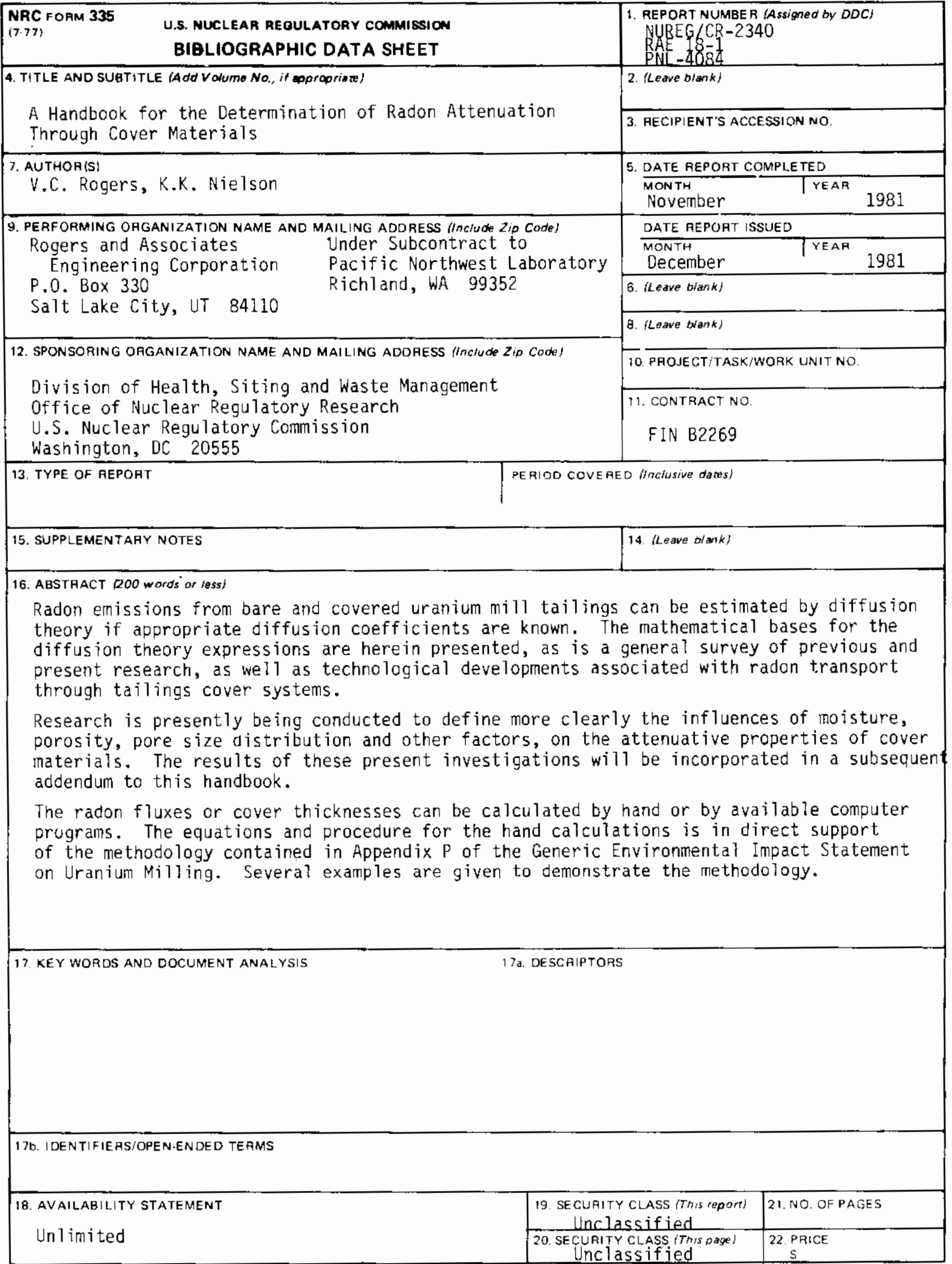


